Illinois State University

ISU ReD: Research and eData

Theses and Dissertations

3-18-2015

\title{
The Countryman: Joseph Addison Turner and the Cultural Construction of Confederate Nationalism
}

Christina Lea Smith

Illinois State University, historian1861@gmail.com

Follow this and additional works at: https://ir.library.illinoisstate.edu/etd

Part of the United States History Commons

\section{Recommended Citation}

Smith, Christina Lea, "The Countryman: Joseph Addison Turner and the Cultural Construction of Confederate Nationalism" (2015). Theses and Dissertations. 358.

https://ir.library.illinoisstate.edu/etd/358

This Thesis is brought to you for free and open access by ISU ReD: Research and eData. It has been accepted for inclusion in Theses and Dissertations by an authorized administrator of ISU ReD: Research and eData. For more information, please contact ISUReD@ilstu.edu. 
THE COUNTRYMAN: JOSEPH ADDISON TURNER AND THE CULTURAL CONSTRUCTION OF CONFEDERATE NATIONALISM

\author{
Christina Lea Smith
}

133 Pages

May 2015

This master's thesis starts from the premise that Confederate nationalism was not just a political entity, but a cultural project. It examines the role of print culture in shaping a distinctive and unified Confederate community. Emerging on the eve of the Civil War, Confederate nationalism flourished due to the creation and dissemination of southern print culture through newspapers and magazines. This thesis approaches the development of Confederate cultural nationalism through a case study of Joseph Addison Turner, who wrote and edited a weekly journal, The Countryman, from 1862 to 1866. Through The Countryman, Turner advocated and shaped white southern beliefs and perceptions in an effort to unite southerners around a common goal of an autonomous nation. By showing how Joseph Turner fostered a southern cultural movement to forge a patriotic bond amongst white southerners, this research highlights the importance of print culture in the construction of Confederate nationalism. 
THE COUNTRYMAN: JOSEPH ADDISON TURNER AND THE CULTURAL CONSTRUCTION OF CONFEDERATE NATIONALISM

CHRISTINA LEA SMITH

A Thesis Submitted in Partial Fulfillment of the Requirements for the Degree of

MASTER OF SCIENCE

Department of History

ILLINOIS STATE UNIVERSITY

2015 
Copyright 2015 Christina Lea Smith 
THE COUNTRYMAN: JOSEPH ADDISON TURNER AND THE CULTURAL CONSTRUCTION OF CONFEDERATE NATIONALISM

CHRISTINA LEA SMITH

COMMITTEE MEMBERS:

Amy L. Wood, Chair

Stewart Winger

Ronald Gifford

Linda Clemmons 


\section{ACKNOWLEDGMENTS}

This project has taken on a life of its own. Writing anything this substantial and complex over the last couple of years becomes consuming, not only for myself, but for those who contributed in countless ways to the final product. Foremost, I would like to express my sincere gratitude to my committee chair, Dr. Amy Wood, for her continuous support of my study and research, for her patience, motivation, and immense knowledge. Most importantly, I appreciate her constructive critique of my writing. She has taught me invaluable lessons through constant revisions. I could not have imagined having a better advisor or mentor for this project.

Additionally, I would like to thank each of my committee members: Dr. Linda Clemmons, whose knowledge of the northern antebellum era provided me with the much needed balance in my thesis; Dr. Stewart Winger, whose insightful comments and hard questions helped me dive deeper into those tough religious topics; and Dr. Ron Gifford for his valuable time in reviewing my many chapter revisions.

This project was, by far, the most challenging I have completed to date. And I am certainly wiser in so many ways as a result. I cannot express my gratitude enough for being able to work with such a professional, knowledgeable, and wonderful committee, department, and university. 


\section{CONTENTS}

Page

ACKNOWLEDGMENTS

CONTENTS

ii

FIGURES

iv

\section{CHAPTER}

I. INTRODUCTION 1

The Southern National Anthem $\quad 1$

Confederate Nationalism 4

Imagined Community $\quad 7$

Historiography 9

Turner's Early Literary Career 15

The Countryman 17

II. SOUTHERN LITERATURE 23

The Cultural Movement for Intellectual Independence 25

A Truly Southern Culture $\quad 29$

Practical Challenges $\quad 34$

Conceiving a Native Literature 40

The Failure of Confederate Print Literature 52

III. RELIGION 56

The Folly of Fanaticism 61

Turner's Religiosity 64

Sectional Discord $\quad 67$

God's Divine Plan $\quad 69$

$\begin{array}{ll}\text { Sinning and Appeasement } & 73\end{array}$

Death and Suffering as God's Will 78

Virtue $\quad 85$

$\begin{array}{ll}\text { Post-War } & 89\end{array}$ 
$\begin{array}{ll}\text { IV. SLAVERY } & 92\end{array}$

Defending Slavery 93

Class Struggles $\quad 105$

The Emancipation Proclamation 108

Sherman's March through Georgia 110

Slaves in the Confederate Army 113

The Poor Free Slave 117

$\begin{array}{ll}\text { V. CONCLUSION } & 123\end{array}$

$\begin{array}{ll}\text { REFERENCES } & 128\end{array}$ 


\section{FIGURES}

Figure $\quad$ Page

1. The Countryman 19

2. The Confederate Seal 73

3. Five slaves from Joseph Addison Turner's Turnwold Plantation in Eatonton, Georgia. Several of Turnwold Plantation slaves became models for Uncle Remus, Aunt Tempy, and other figures in the African American animal tales immortalized by Joel Chandler Harris. 


\section{CHAPTER I}

\section{INTRODUCTION}

The Southern National Anthem

"God save the South!

God save the South,

Her Altars and Firesides!

God save the South!

Now that war is nigh,

Now that we're armed to die,

Chanting our battle cry,

Freedom or Death!

God be our shield,

At home or in field:

Stretch thine arms over us,

Strengthen and save!

What though they're three to one,

Forward each sire and son,

Strike till the battle's won,

Strike to the grave!

God make the right,

Stronger than might!

Millions would trample us,

Down with their pride!

Lay Thou their legions low,

Roll back the ruthless foe,

Let the proud spoiler know

God's on our side!

Fame! Honor call, Summoning all, Summoning all of us Unto the strife.

Sons of the South, awake, Strike till the bounds shall break!

Strike for dear honor's sake, 


\section{Freedom and Life!}

Rebels before

Our fathers of yore:

Rebel, the glorious name,

Washington bore,

Why, then be ours the same,

The name that he snatched from shame,

Making it first in fame,

Foremost in war.

War to the hilt, Theirs be the guilt, Who fetter the freeman, To ransom the slave. Then still be undismayed, Sheathe not the battle-blade,

Till the last foe is laid

Low in the grave!

- The Southern National Anthem

Published in 1862, within the pages of The Countryman was "The Southern National Anthem."1 Although not the officially sanctioned song of the Confederacy, it was published in newspapers throughout the South. Written by a young Confederate soldier, the song represented the Confederacy for him and thousands of others. The first three verses focus on God: God save the South; God be our shield; and God make the right. Each of these verses places God as the key figure in the war as though he protected the South and her institutions from losing their fight for independence. The fourth verse urges southern men to take up arms and fight for the cause. The fifth verse looks back to their ancestors, the founding fathers. This reinforced the idea that southerners were walking in the footsteps of their revolutionary ancestors who fought for their freedom. The song closes with a final verse on slavery and how the North held the freeman in

\footnotetext{
${ }^{1}$ Joseph Addison Turner, "The Southern National Anthem," The Countryman (Sep 29, 1862): 5.
} 
bondage to ransom the slave's freedom. These ideas represented the foundation of Confederate nationalism.

Nationalism constitutes a form of group loyalty toward the nation-state based on shared feelings and common ideas. ${ }^{2}$ In nationalistic terms, southerners felt a sense of identity as Americans, but also as southerners. As tensions built over the preservation and expansion of slavery in the decades leading up to the American Civil War, southerners came to believe they no longer shared the same values and interests with northerners. Southern identity, which represented their shared regional interests in society, their way of life, and more specifically, the institution of slavery, led to the development of southern nationalism. Southern identity acted as a unifying force during the antebellum period and through the secession crisis. It was not until the formation of the Confederate States of America, however, that identity evolved into a national spirit known as Confederate nationalism. In sum, southerners rallied around their identity to defend their common interests while part of the United States, but during the Civil War shifted their loyalties to the Confederate nation.

This thesis analyzes Joseph Addison Turner, a southern slaveholder, planter, writer, and cultural nationalist who published a prominent journal, The Countryman from March 4, 1862 until May 8, 1866. Through The Countryman, Turner used print culture to forge a Confederate identity during the war. His journal helped to shape the ideals that united southerners to support an independent southern nation. As one of the most widely circulated and read papers in the Confederacy, The Countryman's readership exceeded two thousand during the war, reaching readers in Virginia, Georgia, Mississippi,

\footnotetext{
${ }^{2}$ David M. Potter, "The Historian's Use of Nationalism and Vice Versa," The American Historical Review, Vol. 67, No. 4 (July 1962), 935-936.
} 
Tennessee, North Carolina, South Carolina, Florida, Alabama, Louisiana, and Texas. ${ }^{3}$ No other southern newspaper or journal boasted those subscription numbers. The Countryman's articles also appeared in northern papers, such as the Lowell Daily Citizen and News in Lowell, Massachusetts and The Daily Miner's Register in Central City, Colorado. ${ }^{4}$ The literary and financial success achieved by The Countryman allowed Turner to bridge a wide geographical gap in order to build consensus around his ideology of Confederate nationalism.

\section{Confederate Nationalism}

The antebellum period found Americans grappling with political, economic and social issues that divided the population based on their group loyalties and self-interests. Similar to today, people identified with being an American, but also aligned themselves with subsets of other identities, such as political parties, religious denominations, or various organizations. Americans joined other groups based on shared beliefs and common feelings, but these associations did not diminish a person's American identity. Regardless of those other affiliations, people continued to identify themselves as Americans in addition to being northerners, southerners, abolitionists, or slaveholders. ${ }^{5}$

The decades before the Civil War and the secession crisis in the winter of 1860 and 1861, however, challenged southerners' American identity; their American patriotism gave way to their sectional southern identity and the rise of nationalism for an

\footnotetext{
${ }^{3}$ Joseph Addison Turner, "Third Volume," The Countryman (Sep 29, 1862): 1.

4 "To the editor of the Eatonton (Ga.) Countryman," Lowell Daily Citizen and News (Dec 30, 1864); “To the editor of the Eatonton (Ga.) Countryman," The Daily Miner's Register (Jan 11, 1865). The Countryman's articles that appear in the northern newspapers are reprinted articles with "good-humored reflections" that Turner wrote discussing Union troop movement through Georgia. These northern newspapers used Turner's eye-witness accounts to mock the reactions of how southerners handled the Union occupation of their land.

5 David M. Potter, "The Historian's Use of Nationalism and Vice Versa," The American Historical Review, Vol. 67, No. 4 (July 1962), 925-932.
} 
independent southern nation. Confederate nationalism, according to historian Paul Quigley, was a combination of a political and ethnic form of unity that drew upon American political traditions. As southerners saw themselves as the true heirs of the American republic, they believed that northerners no longer held the same republican principles of liberty, freedom, and self-government as the nation's forefathers had intended. Civic nationalism, according to Quigley, allowed the South to reject the government of the United States and create their own. ${ }^{6}$ Southerners also invoked the feeling of victimhood to portray the North as a bully infringing upon southern rights and traditions.

In addition, Quigley argues that southerners were influenced by the European separatists' movements of the 1840s and 1850s in Hungary, Czechoslovakia, and Poland that looked to their ethnicity and culture to define their nation's borders. As a result, these movements excluded people with a different ethnicity. Following this ethnic model of nationalism, southerners used slavery to defend their ethnicity as white citizens of the Confederacy; the southern nation, which excluded blacks, was thus a white supremacist one. From these shared beliefs around race, freedom, culture, and slavery, southerners created a regional form of American nationalism. ${ }^{7}$

Yet, although southerners attempted to distinguish their culture and society from the North, there were more similarities than differences between the two regions. Both believed in individual liberty (for whites). Northerners and southerners spoke the same language and shared the same religion. Geographically they were roughly the same size.

\footnotetext{
${ }^{6}$ Paul Quigley, Shifting Grounds: Nationalism and the American South 1848-1865 (Oxford: University Press, 2012), 30.

${ }^{7}$ Paul Quigley, Shifting Grounds: Nationalism and the American South 1848-1865 (Oxford: University Press, 2012), 30-36, 67-69, 76, 78.
} 
They had a common heritage and history. Both embraced westward movement and expansion. Although the North had a larger industrial base, economically both sides were primarily agricultural, and the cotton market had created a mutually beneficial relationship. And both North and South were vastly unequal societies; prior to the Civil War one half of the white male population owned less than one percent of any property, real or personal with the wealthiest owning twenty-seven percent. ${ }^{8}$

The primary difference between the regions and the thing that ultimately split them apart was their labor systems. While slavery, by itself, certainly did not create a separate society, culture, or nation, it became the cornerstone of southern nationalism. While racism was widespread throughout the United States, the South's slave culture was not. Southern identity was formed around race, and more specifically around the idea that the white man was superior to the black man. This racial hierarchy was supported by notions of property rights. Southern propertied men were considered equal regardless of their slaveholding status. As property owners, these men dominated their wives, children, farm hands, and slaves. By keeping women in an inferior position, non-slaveholders were elevated in society, which allowed them to experience and share in the mastery of their households, similar to slaveholders. ${ }^{9}$

By building their society around a racial hierarchy and slavery, southerners created an identity different from the North. This bond was solidified even further with the emergence of the anti-slavery movement in the 1830s when southerners found

\footnotetext{
${ }^{8}$ Edward Pessen, "How Different from Each Other Were the Antebellum North and South?" The American Historical Review, Vol. 85, No. 5 (Dec 1980), 1119-1149.

${ }^{9}$ Stephanie McCurry, Masters of Small Worlds: Yeoman Households, Gender Relations, the Political Culture of the Antebellum South Carolina Low Country (New York: Oxford University Press, 1995), 16-19, 93.
} 
themselves on the defensive about their society and way of life. From the outspoken opposition against slavery in the North, southerners feared the two regions no longer shared the same ideals. They perceived the abolitionists' actions as a personal attack on their honor, their culture, and their way of life. As a result, a sense of urgency emerged. The South must form its own nation or perish trying. ${ }^{10}$

\section{Imagined Community}

In uniting white southerners around common beliefs and values, Confederate nationalism constituted what Benedict Anderson has called an "imagined community." The population of the antebellum South made it impossible for every person to connect to one another. Physical personal interactions were confined to the inner circle of citizens' daily lives, but the abstract notion of a common southern interest allowed people to envision a community with similar culture, customs, traditions, social institutions, and government. These mental bonds established the "imagined community" of the Confederacy. In this sense, the Confederacy was not only a political entity, but a cultural entity as well.

As Anderson argues about eighteenth and nineteenth century Europe, these binding ties were initially forged through the print industry. For European nations that had several dialects amongst its people, the written word in their common language was mutually understood. ${ }^{11}$ While the South did not have a language barrier, southerners used the printed word to unite their people around southern ideology. Increased literacy, the

\footnotetext{
${ }^{10}$ Paul Escott, "The Failure of Confederate Nationalism: The Old South's Class System in the Crucible of War," in The Old South in the Crucible of War, ed. Harry P. Owens and James J. Cooke (Jackson: University Press of Mississippi, 1983), 17; Paul Quigley, Shifting Grounds: Nationalism and the American South 1848-1865 (Oxford: University Press, 2012), 11, 52-55, 143-145.

${ }^{11}$ Benedict Anderson, Imagined Community: Reflections on the Origin and Spread of Nationalism (London: Verso, 2006), 26-28.
} 
rise of southern newspapers and journals, and the development of the print infrastructure to support those intellectual pursuits allowed the print industry to create a southern “imagined community." As a result, the nationalization of print cultivated a much larger commitment to the Confederate nation as a whole. ${ }^{12}$

The appeal of Confederate nationalism transformed Turner's The Countryman into one of the most widely circulated newspapers during the Civil War. Turner's use of southern print culture allowed him to unite southerners across an "imagined community" in support of southern ideals cannot be overstated; as print literature, the paper encouraged, educated, and influenced southern readers to rally around the idea of an independent southern nation.

Turner wrote and published several articles that defined the united Confederate nation and its people. In an 1864 article entitled "Causes of Complaints," Turner referenced all southern people as the "country" or "nation," but also called them as the "people." 13 Turner used the broad classification of "the people" to unite otherwise diverse peoples across the southern states into one collective unit of like-minded individuals. It was this type of conscious and deliberate construction of the "imagined community" that solidified the notion of a southern nation. He took his idea of a nation further when in 1865, just three days after Lee's surrender, he used a definition from a volume of Emile Souvestre's article "An Attic Philosopher in Paris.”

[I]t is all that surrounds you, all that has brought you up, and fed you, all that you have loved!"... The laws which protect you, the bread which pays for your work, the words you interchange with others, the joy, and grief which come to you from the men, and things among which you live - this

\footnotetext{
${ }^{12}$ Benedict Anderson, Imagined Community: Reflections on the Origin and Spread of Nationalism (London: Verso, 2006), 61-62.

${ }^{13}$ Joseph Addison Turner, "Causes of Complaints," The Countryman (Jul 26, 1864): 1.
} 
is your country!...You see it, you breathe it, every where! Think to yourself of your rights, and your wants, you past and your present blessings: write them all under a single name - and that name will be your country! ${ }^{14}$

Using Souvestre's description, Turner recognized that a nation was not simply a political union connected by government, laws, and markets, but was also joined together by shared emotions and physical connections to one another. It also focused on the collective rights and wants, which represented for Turner the right to hold property in slaves and the desire for an autonomous nation.

\section{Historiography}

Historians have longed discussed the factors that gave rise to the Confederacy as a political or military elite, but only recently have they examined the cultural forces that created a sense of distinct southern identity and nationhood. Consensus among them suggests that Confederate nationalism was not created until the start of the war. Yet, historians have emphasized different factors in defining that nationalism. Drew Gilpin Faust's The Creation of Confederate Nationalism, published in 1988, was the first to examine the concept with any depth. Faust argues that it was the South's existing social institutions that allowed people, separated by race, class and gender, to construct a consensus at home, in order to forge the foundation for a new nation. ${ }^{15}$ As she sees it, religion was the primary institution at the foundation of this new nation. Christianity, as preached by southern clergyman, encouraged individual redemption and personal salvation. Each southerner was called to be individually virtuous in order for the

\footnotetext{
${ }^{14}$ Joseph Addison Turner, "Your Country!" The Countryman (Apr 11, 1865): 222. Emile Souvestre (1806-1854) was the original author of the poem, however, the original publication date could not be located.

${ }^{15}$ Drew Gilpin Faust, The Creation of Confederate Nationalism: Ideology and Identity in the Civil War South (Baton Rouge: Louisiana State University Press, 1988), 21-33.
} 
collective southern people to be morally superior. Southerners contrasted themselves against what they perceived to be the market-driven, corrupt, and immoral northerners who advocated sinful social changes such as women's rights and abolitionism, instead of focusing on individual redemption from sin. Being virtuous was synonymous with patriotism. Alternatively, a sinful South meant defeat, as God would strike down evil.

During the war, religious overtures were not only made by southern clergyman, but also by the Confederate government, which called for fasting and prayer days to reinforce Confederate nationalism. Religion as a public institution became a social unifier that reached almost everyone. All white southerners, politicians, slaveholders, nonslaveholders, and women, felt a moral obligation to God, and by extension the South. ${ }^{16}$

Religious faith was also used to defend southern institutions, especially slavery, which depended upon the support of both slaveholders and non-slaveholders. Recognizing that slavery was a contentious issue amongst non-slaveholders, southern religious leaders broadened their reach to all white southerners to explain the importance of black racial subordination in shaping the Confederacy's republican ideals of equality. ${ }^{17}$ Confederate nationalists also used the Bible to defend slavery, claiming it was a benevolent system in which masters cared and provided for their slaves, including their salvation. According to Faust, white southerners considered slavery to be a "moral strength." Religion justified slavery as a righteous labor system in order to promote a

\footnotetext{
${ }^{16}$ Drew Gilpin Faust, The Creation of Confederate Nationalism: Ideology and Identity in the Civil War South (Baton Rouge: Louisiana State University Press, 1988), 21-33.

${ }^{17}$ Drew Gilpin Faust, The Creation of Confederate Nationalism: Ideology and Identity in the Civil War South (Baton Rouge: Louisiana State University Press, 1988), 72-73.
} 
social order in which all white men were considered equal regardless of their slaveholding status. ${ }^{18}$

More recently, Paul Quigley's Shifting Grounds has drawn on themes of shared victimhood and suffering that united all southern people. This common emotional and psychological bond was what drew the southern people together. Quigley sees the construction of Confederate nationalism as something that was forged through the experience of war. As the war waged, white southerners rallied together in the face of death and suffering as each individual and family was affected in some fashion by the atrocities that the North brought against the South. The ultimate sacrifice was death, which only strengthened the Confederate nation. ${ }^{19}$

Similar to Faust, Quigley suggests that southerners believed they must be morally just in order to stay in God's good graces. It was the moral power of the southern people that determined the outcome of the war. Quigley argues that the southern people believed God, who had chosen them to create a Christian republic despite the bullying tactics of the immoral and corrupt North, was the director of the Civil War. Southern oppression by the North kept God on their side. ${ }^{20}$

Ian Binnington's Confederate Visions: Nationalism, Symbolism, and the Imagined South in the Civil War, on the other hand, focuses on the ways in which Confederate nationalism operated as a collection of symbols that all white southerners, male and

\footnotetext{
${ }^{18}$ Drew Gilpin Faust, The Creation of Confederate Nationalism: Ideology and Identity in the Civil War South (Baton Rouge: Louisiana State University Press, 1988), 21-33.

${ }^{19}$ Paul Quigley, Shifting Grounds: Nationalism and the American South 1848-1865 (Oxford: University Press, 2012), 9-10.

${ }^{20}$ Paul Quigley, Shifting Grounds: Nationalism and the American South 1848-1865 (Oxford: University Press, 2012), 198-207.
} 
female, could draw upon with common meaning and understanding. ${ }^{21}$ Binnington argues that the collective understanding of these symbols united southerners around common themes, including the Confederate Constitution, currency, and southern military leaders. Through the creation of these southern symbols, the Confederacy mobilized a nationalistic spirit. More importantly, these symbols supported and defended southern institutions.

In particular, Binnington recognizes the importance of native literature as a unifying symbol for southern people. Writers attempted to convince southerners that a common bond existed between them that justified their own nation. Southern literati in their poetry, fiction, and history wrote about the juxtaposition of the North and South in order to create a sense of common identity. In these works, the South was portrayed as the defender of liberty, while the North was seen as radical and corrupt. The South had been forced to live by northern rules. Southern writers argued that the South had a civilized society, while the North's was based on barbarity. It was this dichotomy of good versus evil that created the sense of collective identity through literature. ${ }^{22}$

Binnington, like Faust, sees slavery as a point of contention between slaveholders and non-slaveholders. As Confederate independence rested on slave labor, southerners realized that "one simply could not exist without the other." ${ }^{, 23}$ In order to head off any class divisions between slaveholders and non-slaveholders, Binnington suggests that the image of slavery was minimized in everyday life. In order to accomplish this, slavery was

\footnotetext{
${ }^{21}$ Ian Binnington, Confederate Visions: Nationalism, Symbolism, and the Imagined South in the Civil War (Charlottesville: University of Virginia Press, 2013), 54.

${ }_{22}^{22}$ Ian Binnington, Confederate Visions: Nationalism, Symbolism, and the Imagined South in the Civil War (Charlottesville: University of Virginia Press, 2013), 144-145.

${ }^{23}$ Ian Binnington, Confederate Visions: Nationalism, Symbolism, and the Imagined South in the Civil War (Charlottesville: University of Virginia Press, 2013), 12.
} 
intentionally left out of the symbols uniting the South. For example, slaves were depicted as secondary silent characters in southern literature where they were quiet, docile, respectful, and appreciative of their position in society. ${ }^{24}$

Finally, Michael Bernath's Confederate Minds: The Struggle for Intellectual Independence in the Civil War South examines the formation of a southern intellectual movement through the efforts of Confederate cultural nationalists. Looking beyond political independence, Bernath focuses on the ways in which southern editors, writers, educators, and poets sought liberation from northern domination of print culture to create their own native literature. Cultural nationalists successfully produced a print industry capable of handling the immediate news needs of southerners, which Bernath calls a “Literature of Knowledge.” However, wartime struggles challenged their goal of creating a permanent literature, which he defines as a "Literature of Power." The fall of the Confederacy ended the southern cultural movement; yet Bernath demonstrates the ways in which, even for a short time, that Confederate cultural nationalists shaped and influenced the South's intellectual discourse and print industry. ${ }^{25}$

The first three scholars, Faust, Quigley, and Binnington, suggest that one of the crowning achievements in creating a national identity was southerners' ability to effectively distinguish themselves from northerners. It was the virtuous versus the sinful. By calling on their shared notions of victimhood, suffering, and sacrifice, southerners convinced themselves that they had a common national identity. Bernath, on the other hand, argues that southerners grappled with clearly articulating the definition of southern

\footnotetext{
${ }^{24}$ Ian Binnington, Confederate Visions: Nationalism, Symbolism, and the Imagined South in the Civil War (Charlottesville: University of Virginia Press, 2013): 175.

${ }^{25}$ Michael T. Bernath, Confederate Minds: The Struggle for Intellectual Independence in the Civil War South (Chapel Hill: University of North Carolina Press, 2010), 2-9.
} 
distinctiveness in print literature. On the whole, however, their interpretations are not mutually exclusive. By focusing on different aspects of Confederate nationalism, whether religious bonds, secular bonds, national symbols, or intellectual culture, these historians together provide a full picture of Confederate nationalism.

In this thesis, I will add to this body of scholarship by focusing on the ways in which Confederate nationalism evolved into a collective belief through the nationalization of print literature. Cultural nationalists, such as Turner, created a national identity through the fostering of a native southern literature. His personal beliefs about religion, slavery, and southern literature did not typically align with mainstream southern views; yet, Turner successfully projects those beliefs in The Countryman to help shape southern perceptions on Confederate independence.

To date, much of the scholarly work on Joseph Addison Turner has focused on his life, political career, and the wide array of his literary papers. Michael T. Bernath uses Turner as an example in the larger southern intellectual movement during the war to illustrate how his literary journal worked towards southern independence. There have been other references to Turner and The Countryman in Faust's The Creation of Confederate Nationalism, The Confederate Reader edited by Richard B. Harwell, and Binnington's Confederate Visions. But the most extensive work on Turner that by Lawrence Huff, dates to the 1960s and focuses on politics, philosophy, and the culture of antebellum Georgia. Since there has been no sustained historical examination of Turner since then, there is still more room for discussion and debate around how Turner used The Countryman to define and promote Confederate identity. 


\section{Turner's Early Literary Career}

Turner's love for journalism and the South did not begin with the formation of the Confederacy. As an early southern advocate in the 1840s, Turner believed the South should be intellectually independent because he found northern thought to be harmful to southern society and institutions. As a result, he urged southerners to create a separate and distinct literature and support local print enterprises. In 1848, Turner published his

first journal, Turner's Monthly. ${ }^{26}$ But for all his hard work and pleading for subscriptions, Turner's Monthly failed after three months due to lack of patronage. Southern readers, Turner reckoned, wanted southern periodicals, but were not willing to read them until they were successful. ${ }^{27}$

Despite his advocacy for southern cultural independence, Turner initially stood against secession. In April 1854, Turner published The Independent Press, a weekly journal in which he urged his fellow Democrats to take a strong stance against disunion. Aligning himself with the national Democratic Party rather than the regional faction, Turner feared that the radicals within the party would cause friction within and tear apart a strong national party. He hoped The Independent Press would be the mouth of the Democratic Party, but unfortunately the paper did not turn a profit. Again, Turner shut it down. ${ }^{28}$

In 1857, Turner shifted from a literary career to politics when he ran on the Democratic ticket for the Georgia State Senate. He faced opposition from his own party,

\footnotetext{
${ }^{26}$ Joseph Addison Turner, “A Familiar Talk With My Readers,” The Countryman (Jan 12, 1864): 1.

${ }^{27}$ Michael T. Bernath, Confederate Minds: The Struggle for Intellectual Independence in the Civil War South (Chapel Hill: University of North Carolina Press, 2010), 1-2.

${ }^{28}$ Lawrence Huff, "Joseph Addison Turner: A Study in the Culture of Ante-Bellum Middle Georgia" (PhD diss., Vanderbilt University, 1958), 157-158.
} 
which Turner claimed was jealous of his rising popularity, and the Know-Nothing Party as he had written articles against their platform. Losing in 1857, Turner successfully ran again in 1859 as an Independent. ${ }^{29}$ While in office, he continued to advance his politics and southern viewpoints on slavery and states' rights by publishing The Plantation - A Southern Quarterly Review. In March 1860, it read:

The special feature of this Journal will be defense of Negro Slavery total, unqualified, unreserved - in a moral, social, and political point of view. In whatever aspect the question presents itself, "The Plantation" will be found the champion of the "peculiar institution" of the South, and will counsel that section to maintain its just rights under the Constitution, and as sovereign states, in the teeth of all opposition, at all hazards, and to the last extremity. ${ }^{30}$

Turner used The Plantation to advocate for the maintenance and expansion of slavery.

However, his dream of a successful and profitable periodical once again failed. After four issues, The Plantation ended publication due to the outbreak of the Civil War.

When the secession crisis came to a head, Turner, as an Independent, did not find any political allies in the Georgia State Senate. He neither advocated secession, in which one region could exit an existing nation, nor did he want unconditional submission in order to remain within the Union. Instead, Turner advocated for a "peaceable dissolution of the Union," which was not secession, but a complete termination of the American experiment. ${ }^{31}$ In his views, the American nation had failed as an entity; therefore, it should be completely dissolved in order for the regions to form new nations. When Turner's recommendation to dissolve the Union was ignored and the secession debate

\footnotetext{
${ }^{29}$ Thomas H. English, ed., Autobiography of “The Countryman,” 1886. (Georgia: The Library Emory University, 1943), 20-23.

${ }^{30}$ Lawrence Huff, "Joseph Addison Turner: A Study in the Culture of Ante-Bellum Middle Georgia" (PhD diss., Vanderbilt University, 1958), 210-211.

${ }^{31}$ Thomas H. English, ed., Autobiography of “The Countryman," 1886. (Georgia: The Library Emory University, 1943), 15.
} 
continued, he felt powerless against the number of fire-eaters advocating immediate secession. $^{32}$

Once secession occurred, however, Turner remained loyal to his home state of Georgia and the newly formed Confederacy. Although he did not agree with secession, he stated that he must be true to his section, "just as I would be true to my mother, admitting she could be in error." ${ }^{, 33}$ Even though Turner came late to the idea of secession, he fully embraced the same loyalties, such as the preservation of slavery and the creation of a native literature, as the earlier secessionists. Politically, Turner never sought reelection. With the formation of the new southern nation, he recognized the critical timing and importance in the nationalization of southern print literature. In 1862, The Countryman emerged as Turner's mouth piece advocating a politically, economically, socially, and intellectually independent nation free from northern influences.

\section{The Countryman}

The Countryman was Turner's greatest accomplishment and contribution to southern literature and to the advancement of the Confederate nation. The Countryman differed from his earlier literary ventures since Turner's pre-war publications specifically focused on preserving the southern way of life. Southern ambitions, Turner believed, had shifted from simply defending southern institutions to creating a new Confederate nation that supported those institutions. The Countryman focused on the problems plaguing the newly formed nation, including the development of a native southern literature, the creation of southern unity and patriotism, and support for the war effort. As a cultural

\footnotetext{
${ }^{32}$ Lawrence Huff, “Joseph Addison Turner's Role in Georgia Politics, 1851-1860, The Georgia Historical Quarterly, Vol. 50, No. 1 (March 1966), 1-13.

${ }^{33}$ Joseph Addison Turner, "His Excellency, Andrew Johnson, President of the United States," The Countryman (Feb 20, 1866): 27.
} 
nationalist, Turner saw political autonomy equally as important as intellectual independence. Every aspect of southern society hinged on a sovereign Confederate nation.

Early in the publication of The Countryman, Turner identified his target audience as influential editors, politicians, generals, intellectuals, and religious leaders in the South. ${ }^{34}$ He refused to cater to the masses; instead he wanted to influence those who held power within the Confederacy, especially the planter class. To do this, The Countryman ran several articles devoted to planter interests, such as agriculture, stock raising, and field sports. ${ }^{35}$

Turner targeted the planter class and southern elite to influence Confederate policy and ideas from the top down. The name for his enterprise - The Countryman reflected this approach and could have two distinct meanings. It might have represented patriotism that would cater to the masses of southern people. Yet, the more likely interpretation is that it references a rural countryman, or more specifically a planter. Turner himself said that "[i]t is emphatically a country paper, and will represent the interests of the country." 36 The word "country" implied a rural setting such as a plantation, but it also represented the new southern nation. His approach, however, contradicted the notion of a white southern egalitarian society. Slavery had been used to blur class lines by creating the illusion that white southern men controlled their households (wives and children) and their plantations (slaves). In this ideal, slaveholders and non-slaveholders ruled equally. Southerners sought to downplay slavery and

\footnotetext{
${ }^{34}$ Michael T. Bernath, The Struggle for Intellectual Independence in the Civil War South (Chapel Hill: University of North Carolina Press, 2010), 260.

${ }^{35}$ Joseph Addison Turner, "The Countryman," The Countryman (Aug 11, 1863): 48.

${ }^{36}$ Joseph Addison Turner, "Prospectus," The Countryman (Mar 4, 1862): 4.
} 
emphasized inter-class bonds to unify the nation. ${ }^{37}$ Turner, conversely, targeted the movers and shakers by overlooking non-slaveholding southerners. Despite his profiling, The Countryman became one of the most widely circulated papers in the South. With a larger reader base, Turner had constructed a massive community of southerners who read, debated, and articulated their own ideas about southern identity, nationalism, and the nation itself. His nationalization of southern print elevated the importance of Confederate nationalism into a popular belief.

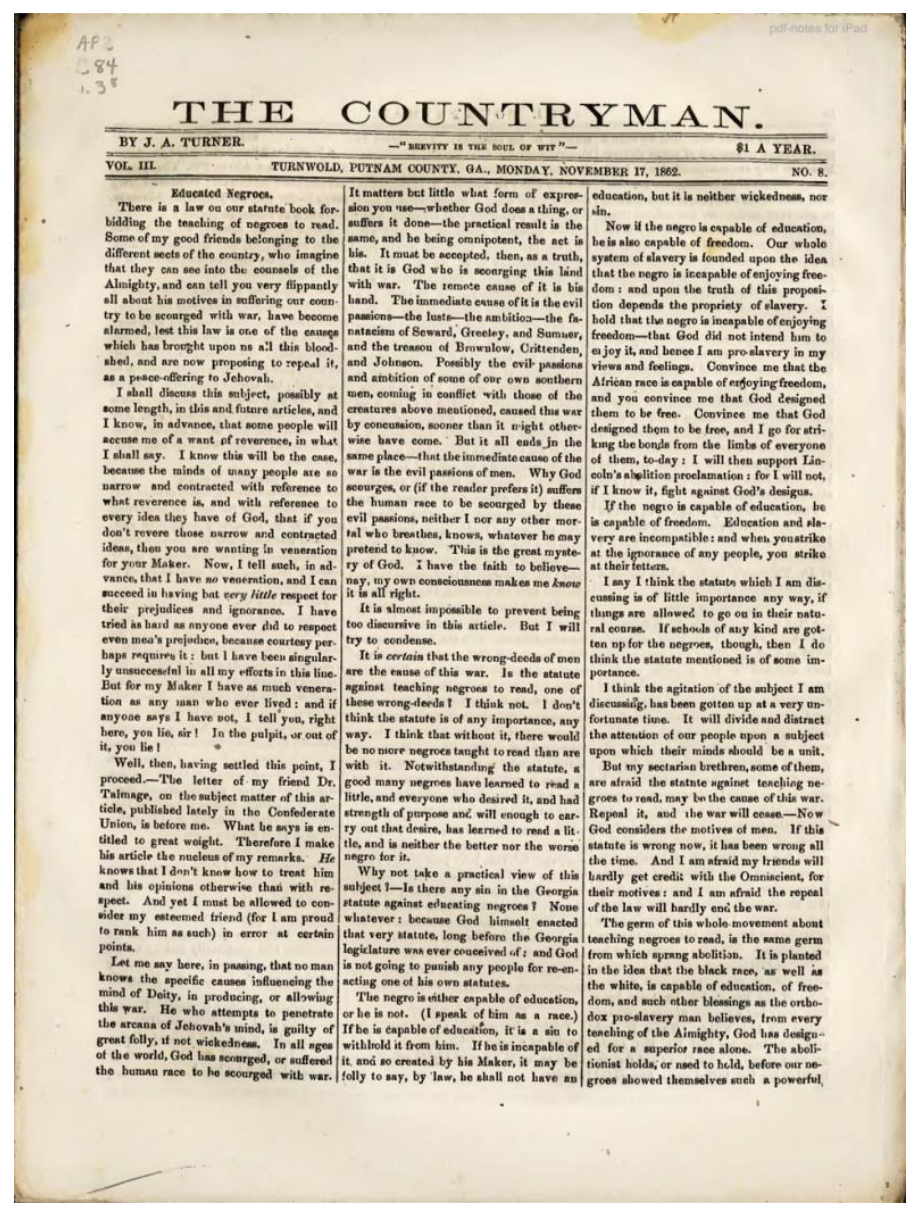

Figure 1. The Countryman

${ }^{37}$ Drew Gilpin Faust, The Creation of Confederate Nationalism: Ideology and Identity in the Civil War South (Baton Rouge: Louisiana State University Press, 1988), 21-33; Ian Binnington, Confederate Visions: Nationalism, Symbolism, and the Imagined South in the Civil War (Charlottesville: University of Virginia Press, 2013), 12. 
Due to Confederate conscription laws, Turner's staff was quite small. Most of the articles written in The Countryman were written by Turner himself, Turner's brother, William Wilberforce Turner, and Joel Chandler Harris, who later became famous for his Uncle Remus stories. Hired at the age of fourteen, Harris was initially Turner's printer's devil, an apprentice learning various aspects of the printing industry, including ink mixing and type setting. Later Turner encouraged Harris in his literary skills and published several of Harris's poems within the page of The Countryman. ${ }^{38}$

Even though Turner and the staff at The Countryman were few, this did not keep them from the scrutiny of the conscription office or criticism from the community. Those on staff were either too young to fight, met the conscription exemption for newspaper editors, or were disabled, including Turner himself. At seven years old, Turner contracted necrosis in his right thigh bone. As the cells in his thigh bone died, Turner spent his boyhood on crutches and was left permanently disabled. ${ }^{39}$ He occasionally expressed his longing to join Confederate forces, but realized that his editorial efforts were far more valuable, or at least that was his conclusion.

Turner felt obligated to explain why he remained at home while his neighbors and friends were off on the battlefield. While he blamed God for inflicting him with such a condition that he had to live with his entire life, Turner rationalized that his position as an editor was more important than the military. Believing that every Confederate person

\footnotetext{
${ }^{38}$ Harris would have spent his formative years working at The Countryman's office located on Turner's plantation and most likely interacted with Turner's slaves. These exchanges might be linked to many of the Uncle Remus stories as Harris insisted his sources were genuine. Harris's apprenticeship abruptly came to an end in 1864 with General William T. Sherman's march to the sea. Sherman's troops invaded Eatonton and more specifically Turner's plantation of Turnwold. Even though the apprenticeship ended, Harris continued to contribute to The Countryman until the end of its publication in 1866. Uncle Remus Bookstore. http://www.uncleremus.com (accessed December 29, 2013).

39 Joseph Addison Turner, "Autobiography of 'The Countryman'," The Countryman (Feb 13, 1866): 20-22.
} 
regardless of race or sex had a daily obligation to support the nation, he justified his time and energy. While self-serving, Turner's explanation of his ailment and its impact on his life could lead a reader to sympathize with him. ${ }^{40}$

Turner's contributions to the Confederate national ideology started with his tremendous effort in the publication of The Countryman from February 1862 until June 1866 with little interruption during the tumultuous war years. The nationalization of literary journalism allowed Turner to promote a Confederate nationalism that was representative of his own southern identity and ideals. The Countryman exposed southern readers to the significance of patriotism and national allegiance, the importance of supporting of the war effort, the benevolence required through brotherly love and charity, as well as the collaboration needed to support white southern society and the importance of the subordination of slaves to Confederate freedom.

After four and half years of publishing The Countryman, Turner left behind thousands of pages that can serve as a gateway to his well-defined notions on the composition of a nation, the elements of patriotism, and the importance of community. This thesis contributes to the scholarship on Confederate nationalism through an analysis of Turner and The Countryman by focusing on three main themes that appear throughout the journal: southern literature, religion, and slavery. While this thesis focuses on print literature, Turner's views on religion and slavery cannot be overlooked as they were central to Confederate identity and were articulated in print.

The first chapter examines Turner's role as a prominent cultural nationalist in the advancement of a native southern literature. Despite wartime obstacles, Turner's

\footnotetext{
${ }^{40}$ Joseph Addison Turner, “A Familiar Talk With My Readers,” The Countryman (Jan 12, 1864): 1-2.
} 
ingenuity and creativity propelled print literature into the southern public eye and made important contributions to southern intellectual discourse. His use of The Countryman demonstrates the initial success of the southern print industry in forging a patriotic bond that unified southerners across the Confederacy.

The second chapter analyzes how Turner developed his own brand of religion, which was rooted within evangelical Protestantism, but was moreso a southern civil religion used to faithfully and patriotically support the Confederacy. In the words of James McPherson, "Religion was central to the meaning of the Civil War, as the generation that experienced the war tried to understand it. ${ }^{, 41}$ Understanding Turner's religious beliefs in the context of the Civil War provides a lens into the larger understanding of the attitudes and beliefs that shaped white southerners' sense of nationalism and their suffering in war.

The final chapter on slavery considers the role of Turner's slaveholding ideals within Confederate nationalism. While he defended the institution of slavery and the importance of the South's hierarchical society, Turner rarely agreed with other southerners on the finer points of pro-slavery defenses. He rejected the biblical defense of slavery and used a pseudo-scientific racism to defend the practice. Yet, Turner himself appeared contradictory on slavery, especially when it served his own purposes or he was looking for support from the larger slaveholding community. Ultimately, Turner's dual role as a cultural nationalist and slaveholder collided in the final months of the war as he abandoned southern independence for the preservation of slavery.

\footnotetext{
${ }^{41}$ James M. McPherson, "Afterword," in Religion and the American Civil War, ed. Randall M. Miller, Harry S. Stout, and Charles Reagan Wilson (New York: Oxford University Press, 1998), 412.
} 


\section{CHAPTER II}

\section{SOUTHERN LITERATURE}

The secession of the southern states and the subsequent formation of the Confederacy began as a struggle of self-interests to protect regional objectives, in particular slavery. ${ }^{42}$ But the struggle for independence soon became a cultural movement wherein southerners sought to define their own distinct culture, including literature and the arts. Battlefield victories brought southerners one step closer to political autonomy, but intellectual independence occurred when the South created their own independent native literature. ${ }^{43}$

Turner was a central figure in the war for southern cultural independence. As early as 1848 , he acknowledged the importance of southern literature and desired to see it prosper. Literature, for Turner, consisted of daily news as well as novels, fiction, history, and poetry that would set the South apart from the rest of the literary world. The war pushed his individual efforts into a collective movement across the South. Turner used The Countryman to encourage southerners to support their nation by subscribing to and reading southern print literature, and he advocated for the development of a native literature reflecting southern taste and character that would stir emotions to a great patriotic fervor. To accomplish this, Turner urged southern men, in addition to their

\footnotetext{
42 David M. Potter, "Historian's Use of Nationalism and Vice Versa," The American Historical Review, Vol. 67, No. 4 (July 1962), 935-936.

${ }^{43}$ Michael T. Bernath, Confederate Minds: The Struggle for Intellectual Independence in the Civil War South (Chapel Hill: University of North Carolina Press, 2010), 1-2.
} 
primary occupations, to become writers and poets. To encourage this behavior, Turner wrote, "The reputation of a great writer should be something southern men strive for." $\mathrm{He}$ believed if a southern man failed at his occupation, then the field of literature had jobs available for the taking. ${ }^{44}$ Yet, while Turner's contributions to the development of native literature were genuine, they were fraught with vagueness, inconsistencies, and were often very critical of southern authors.

Turner's determination for an autonomous southern culture directly shaped The Countryman's content, success, and longevity. The Countryman's articles demonstrate the struggles and challenges that Turner faced in building a southern cultural movement. Yet, despite these struggles he turned The Countryman into one of the most widely read and profitable journals in the Confederacy.

The initiative to find a native southern literature paralleled an earlier drive to create a native American literature. American cultural nationalists between the period of the American Revolution and the Civil War began to construct their own national identity by separating culturally from Europe, especially England. America had been heavily dependent on England and Europe's cultural influences, which left American intellectuals feeling a sense of cultural inferiority. ${ }^{45}$ As a result, American literati, including James Fennimore Cooper and Noah Webster, and later Ralph Waldo Emerson and Henry David Thoreau, set out to build an indigenous American literature that represented the nation's ideals, character, and culture. They pursued new forms of literature that did not imitate the European models, but rather embraced the uniqueness of America, emphasizing

\footnotetext{
${ }^{44}$ Joseph Addison Turner, "Authors," The Countryman (Apr 21, 1863): 18.

${ }^{45}$ Randall Fuller, From Battlefields Rising: How The Civil War Transformed American Literature (New York: Oxford University Press, 2011), 6-8.
} 
themes and topics, such as the untamed wilderness, the majestic mountain ranges, and the rugged landscape. At the same time, they deliberately omitted references to England's government, traditions, history, and social structures. Their challenge was that they wanted to create a literary foundation for America without it being based on much American history. ${ }^{46}$

The Cultural Movement for Intellectual Independence

Southern cultural nationalists, like Turner, similarly attempted to create a separate Confederate literature based on the distinctiveness of the South. Turner prided himself on writing in a very southern style, "marked by distinctive southern sentiment, and antipathy to everything that is anti-southern," as he put it in $1865 .{ }^{47}$ He bragged that The Countryman was the only journal in the Confederacy that was entirely and peculiarly southern. Turner described his journal as "a natural product of the soil - indigenous in everything, and never exotic."48 Turner's local, homegrown nativism was expressed in articles about agriculture, nature, and hunting that reflected the southern life, including the preservation of slavery, the development of southern culture, and the support for the fledging nation. He believed that once southerners read The Countryman and other regional newspapers, periodicals, and novels that they would become emotionally invested in the prosperity and future of the Confederacy.

A common misconception widely held amongst Americans in the nineteenth century and many scholars since that time was that southerners were illiterate, backwoods, and uncultured. Yet, despite this perception, there was a vibrant intellectual

\footnotetext{
${ }^{46}$ V.P. Bynack, "Noah Webster's Linguistic Thought and the Idea of an American National Culture," Journal of the History of Ideas, Vol. 456, No. 1 (Jan-Mar 1984), 99-104.

47 Joseph Addison Turner, "Volume XX," The Countryman (Jan 8, 1865): 1.

${ }^{48}$ Joseph Addison Turner, "Yankee Style," The Countryman (Mar 7, 1865): 136.
} 
literary culture thriving on southern plantations, in towns and villages, and in larger metropolitan areas. Although the South was distanced from the North's publishing cities, there were printing houses located in the southern states. Southern intellectuals lived in the cosmopolitan cities, like Charleston, New Orleans, and Richmond, while the planter elite resided in rural areas. Turner successfully published The Countryman from his plantation nine miles from Eatonton, Georgia. While not the norm, Turner demonstrated that literary success was not driven by one's location, but by one's intellectual and literary capabilities. ${ }^{49}$ By 1850 , the South had one of the highest literacy rates in the world with eighty-one percent among the adult white population. The North's literacy rate was slightly higher at ninety-three percent. As William Gilmore Lehne has written, the "Civil War pitted against each other two of the most literate societies on earth." Furthermore, northerners and southerners alike subscribed to news periodicals outside their geographical area and read books and poetry from authors located throughout the nation. The intellectual and literary communities in the North and South had much in common. American literati above and below the Mason Dixon line developed personal and professional relationships based on their common occupational struggles in obtaining subscribers, collecting subscription fees, and meeting financial challenges. One's stance on politics, slavery, and other issues rarely soured a partnership, as noted in Turner's personal journal. While it started with his earliest childhood memories, Turner's personal journal also documented his personal and professional

\footnotetext{
${ }^{49}$ Michael O'Brien, Intellectual Life and the American South, 1810-1860 (Chapel Hill: University of North Carolina Press, 2010), 20-24.

${ }^{50}$ Beth Barton Schweiger, "The Literate South: Reading Before Emancipation," The Journal of the Civil War Era, Vol. 3, No. 3 (Sept 2013), 331-336.
} 
business throughout his lifetime. ${ }^{51}$ In a letter, included in Turner's journal, he wrote a letter to a New York publishing firm, Miller, Orton and Mulligan, on July 27, 1856 to whom he submitted his poetry for publication. While he assured the company that although they were Republicans, it mattered not to him. But, at the same time, Turner spent an entire page defending the expansion of slavery in the territories while ending the letter stating that he was a "moderate man on the subject of slavery." This illustrates a type of relationship common between northern and southern in the print industry during the antebellum period. Turner's personal conversations about important matters of the day never interfered with his professional relationship. ${ }^{52}$

Despite the South's flourishing intellectual life, the region lacked its own native literature. With the emergence of their own nation, southerners had to assume the lead role in the development of their literary culture where they had previously taken a lesser and subordinate position in the creation of American literary culture. Perceived as uneducated and ignorant, southern literati were determined to demonstrate their literary worth to the North. Since literacy was seen as a progressive or modern idea, the South had to fight the stigma given to them based on their rural regional interests. ${ }^{53}$ Historian, Michael O'Brien captures the essence of the problem in regards to southern literacy, intellectual thought, and print culture with the title of his book, Conjectures of Order. There was the opinion, without much proof or sufficient evidence, that the South had been incapable of intellectual thought or literary contributions bearing merit. As a result,

\footnotetext{
${ }^{51}$ Jonathan Daniel Wells, "Writers, Editors, and Intellectual Exchange Between the Antebellum North and South," The Alabama Review, Vol. 67, No. 1 (Jan 2014), 114-115.

${ }_{52}$ Autobiography of Joseph Addison Turner, Robert Woodruff Library Microforms. Emory University, Emory, Georgia, Jul 27, 1856, 40. Turner never mentioned whether or not they published his work.

${ }^{53}$ Beth Barton Schweiger, "The Literate South: Reading Before Emancipation," The Journal of Civil War Era, Vol. 3, No. 3 (Sept 2013), 337-339.
} 
southern cultural nationalists had developed the same inferiority complex as earlier American cultural nationalists. ${ }^{54}$

The attempts of cultural nationalists to create an indigenous southern literature stemmed from this sense of inferiority. Turner urged the southern people not to be intellectually idle; rather, he advised southerners to be mentally industrious. ${ }^{55} \mathrm{He}$ disputed the idea of southern inferiority by implying that northern intellect was mediocre. In his view, northerners were incapable of broader visions, which left them best suited for menial work. Southerners, on the other hand, possessed the power of grasping larger concepts and were naturally great leaders, generals or politicians. ${ }^{56}$

The South's native intellectual culture did not match the literary output of the North. But, the outbreak of the Civil War necessitated southern literary production. As the blockade severed communication ties with the North, southern intellectuals were forced to create their own print literature in all forms, including newspapers, periodicals, novels, and poems. For the first time, the southern periodical press regulated the content of the news to be disseminated throughout the South. ${ }^{57}$ Turner warned southerners of possible criticisms if they failed to produce their own native literature when he wrote in 1862, "We do not wish to be twitted by the Yankees with our literary poverty: and we do not wish Europeans to enquire with a sneer, not only where are your poets, your

\footnotetext{
${ }^{54}$ Michael O'Brien, Intellectual Life and the American South, 1810-1860 (Chapel Hill: University of North Carolina Press, 2010), 20-24.

55 Joseph Addison Turner, "Firmness of Purpose," The Countryman (Oct 27, 1862): 37.

${ }^{56}$ Joseph Addison Turner, "Northern Intellect vs. Southern," The Countryman (May 10, 1864): 264.

${ }^{57}$ Michael T. Bernath, Confederate Minds: The Struggle for Intellectual Independence in the Civil War South (Chapel Hill: University of North Carolina Press, 2010), 4.
} 
novelists, your historians, your men of science and of art, but where are even your literary journals?" 58

Print literature became critical to the cultural infrastructure being developed throughout the South as it served two main purposes: building a collective community and shaping public opinion. Turner considered print literature the "largest liberty of thought, consistent with the interest of the community." ${ }^{, 59}$ This community required a number of things to be successful, including southern intellectuals producing print materials, a massive readership consuming the literature, and an infrastructure to support its dissemination. Print literature forged a relationship amongst southerners by building a supply and demand market for print materials.

The expansion of print literature also shaped public opinion through the efforts of thinkers who were capable of influencing southern intellectual thought at the Confederate national level. ${ }^{60}$ The success of a national southern literature depended on the reading audience to engage in intellectual discourse about the material. Print literature not only had to reach the masses, but also had to shape the ideas and perceptions of the southern political leadership. Through the elite, southern intellectuals were able to shape public policy and persuade readers to support those policies.

\section{A Truly Southern Culture}

Similar to the American cultural nationalists after American independence, southern cultural nationalists recognized their culture and history could not reflect the

\footnotetext{
${ }^{58}$ Joseph Addison Turner, "Southern Field \& Fireside," The Countryman (May 27, 1862): 4.

${ }^{59}$ Joseph Addison Turner, "A Free Press,” The Countryman (Apr 12, 1864): 204.

${ }^{60}$ Michael O'Brien, Intellectual Life and the American South, 1810-1860 (Chapel Hill: University of North Carolina Press, 2010), 39; Benedict Anderson, Imagined Communities: Reflections on the Origin and Spread of Nationalism (London: Verso, 2006), 61-62.
} 
past and their previous association with their former nations. Looking back to the decades before disunion, southerners realized their past was tightly intertwined with the North. Southern intellectuals became conscious that their new nation needed to reflect strictly a southern culture without competing northern interests and values. In order to accomplish this, southern intellectuals took on a forward-looking mentality wherein the Confederacy had no past. Their inspiration would come from the anticipated Confederate victory, ultimate independence, and the prosperity of southern interests without northern influences. In other words, southern literature looked forward to a politically and intellectually independent nation. While primarily focused on their future, some southern writers did look backward to the American past. But in developing a new southern print literature, they referred to the past only in the strictest terms, describing the regional agrarian aspects that signified the southern way of life, especially the institution of slavery. Even as southern literati used established pro-slavery arguments to defend slavery, they looked to their future of an independent nation to explain why slavery should persevere as a vital aspect of their culture.

Before the war, southern and northern literati contributed to American culture and literature using different themes. Many northern writers were influenced by the antislavery movement, Transcendentalism, and the Enlightenment beliefs of liberty and individualism. Southern writers, on the other hand, wrote about their region, their landscapes, and social institutions, especially the defense of slavery. While northerners discussed liberty, equality, and freedom as the essence of American democracy and republican ideals, southerners wrote about those same principles to support their white solidarity and defend slavery. 
Southern cultural nationalists invoked these same feelings of regional pride by cultivating a distaste for northern culture and a desire for southern cultural autonomy. Turner's articles encouraged that autonomy through proposing the creation of a new national anthem, flag, text books, holidays, domestic manufacturing, and even weights and measures ${ }^{61} \mathrm{He}$ also spoke out against July $4^{\text {th }}$ celebrations arguing that, in his opinion, the South should forget their former place within the United States by "putting ourself in mourning that our forefathers ever quit Great Britain to form an alliance with the demons of yankeedom. ${ }^{, 62}$ Turner's sentiments that the South must develop complete autonomy from any outside influences is evidenced in The Countryman's motto, which for a time boasted the phrase, "Independent in Everything.",63

By framing southern autonomy around the theme of northern hostility, Turner and other cultural nationalists struggled in defining what the South was about; rather, they found it easier to define what the South was not. As a result, their writing exposed more anti-northern hostility and less southern uniqueness. Turner focused on one theme: the South was not the North. Southern literati admonished southerners who mimicked the North in dialect. Turner set out to create a truly native language without northern words that "produce sensations of unmingled and unmitigated disgust" such as "secesh," which is a derogatory term used to describe Confederate soldiers, "abolish," which referenced the abolition of slavery, and "skedaddle," which meant to retreat or depart quickly as southerners would never see themselves as retreating on the battlefield. These Yankee

\footnotetext{
${ }^{61}$ Joseph Addison Turner, "Volume XX," The Countryman (Jan 8, 1865): 1.

${ }^{62}$ Joseph Addison Turner, " 4 th of July," The Countryman (Aug 18, 1863): 51.

${ }^{63}$ Michael T. Bernath, Confederate Minds: The Struggle for Intellectual Independence in the Civil War South (Chapel Hill: University of North Carolina Press, 2010), 18-19.
} 
vulgarisms, in his view, should be kept out of the press, conversation, and writing. ${ }^{64}$ For the sake of their southern reputation, Turner wanted all southerners to make a conscious effort when speaking to "prevent all miserable aping! Do let us have some self respect and independence!" 65 While he might have taken the southern vocabulary farther than most cultural nationalists, Turner was determined to rid southern speech of any northern connection. ${ }^{66}$ This may seem extreme, but it mimicked Noah Webster's earlier antebellum attempt to develop a language distinct from British English. Just as Webster wanted to create American words, such a 'color' from the British version 'colour,' Turner eliminated words that reflected Yankee society. ${ }^{67}$

Beyond language, southern nationalists also wanted to distinguish themselves from other northern radical behavior. Northerners, in their view, had become immoral, unethical, and sinful through the vices of swearing, gambling, and drinking, as well as the greed, materialism, and corruption that industrial capitalism had produced. ${ }^{68}$ More importantly, northerners had accepted changes to their social structures through the rise of movements, such as women's rights and abolitionism. The "isms" of the North, nationalists believed, tainted the moral fabric of society, altered the nation from the founding fathers' original intent, and jeopardized an elite white male supremacist society. $^{69}$

\footnotetext{
${ }^{64}$ William W. Turner, "The Slang," The Countryman (Mar 8, 1864): 1.

${ }^{65}$ Joseph Addison Turner, "Guessing," The Countryman (Oct 6, 1862): 12.

${ }^{66}$ Joseph Addison Turner, "Greek or Yankee," The Countryman (Aug 30, 1862): 2.

${ }^{67}$ V.P. Bynack, "Noah Webster's Linguistic Thought and the Idea of an American National Culture," Journal of the History of Ideas, Vol. 45, No. 1 (Jan-Mar 1984), 104.

${ }^{68}$ Michael T. Bernath, Confederate Minds: The Struggle for Intellectual Independence in the Civil War South (Chapel Hill: University of North Carolina Press, 2010), 36-39.

${ }^{69}$ Drew Gilpin Faust, The Creation of Confederate Nationalism: Ideology and Identity in the Civil War South (Baton Rouge: Louisiana State University Press, 1988), 30-31.
} 
Turner's hatred for northern society can be read throughout The Countryman, particularly through his satirical use of wit and sarcasm that captured his reader's attention. While wartime hardly seemed the appropriate place of parody or humorous writing, especially with the vast sacrifice and suffering felt across the South, Turner's denouncements of the North were meant to elevate southern intellect. Beginning on April 14, 1863, he introduced "The Countryman's Devil," which were brief satirical blurbs written in a question/answer format. They featured sarcastic themes using double entendres. One read: "Why don't old Abe Lincoln join the new party at the North? Because his cranium hasn't got cents enough in it to make it a copper head. ${ }^{, 70}$ Another quipped: "Why will the yankee Secretary of State, when the yankee people shall put him in fetters for his crimes, be like a man about to embark on a voyage? Because he will be Seward bound." "The Countryman's Devil" attacked northern society and all its failings in order to further distance the South from such evil influences.

The question left unanswered by Turner and other cultural nationalists was: what defined the South as southern? He was unable to convey what it meant to be truly southern beyond the vague reference to locality, character, and culture. ${ }^{72}$ Their inability to adequately define southern can be ultimately attributed to the lack of dissimilarities between the North and the South. If the South was so distinct, cultural nationalists would have been able to grasp those differences; instead, the only difference between them was slavery. Southern culture and character revolved around a white supremacist society and

\footnotetext{
${ }^{70}$ Joseph Addison Turner, The Countryman (May 26, 1863): 39.

${ }^{71}$ Joseph Addison Turner, The Countryman (Apr 14, 1863): 14.

${ }^{72}$ Michael T. Bernath, Confederate Minds: The Struggle for Intellectual Independence in the Civil War South (Chapel Hill: University of North Carolina Press, 2010), 18-19.
} 
the subordination of the black race. Beyond plantations, slave labor, and white dominated social order, the South and the North were more similar than different.

\section{Practical Challenges}

Due to the Union blockade of southern ports and harbors, there was an absence of cultural imports. These war-time shortages necessitated southern literary output. Southern editors and writers faced wartime obstacles that limited the amount of available resources for the print industry. From the scarcity of paper and ink to the exorbitant prices, many southern editors struggled daily to produce their required subscription runs. Yet, even during the lean times of war, Turner demonstrated great resourcefulness by overcoming challenges that shut down other literary ventures.

Initially he produced The Countryman in four full sheets. By 1863, many southern newspapers, including The Countryman had been reduced to half sheets or cut back the number of full pages. Turner preferred to use half sheets rather than risk an entire suspension. ${ }^{73}$ But then he used a smaller font type to have the same column space as full sheets and provided two-thirds more reading material. ${ }^{74}$ When one of the southern paper mills from which Turner purchased paper was burned by northern forces, his production continued because he had taken precautionary measures before it was burned by planting a cotton field to a produce his own paper supply. ${ }^{75}$ Turner also regularly advertised for rags or scraps of rope and cloth, for which he paid five to ten cents a pound in hopes of generating additional paper. ${ }^{76}$ These proactive measures attributed to The Countryman's success and longevity. In January 1864, Turner doubled its size to an unbelievable

\footnotetext{
73 Joseph Addison Turner, “Scarcity of Paper," The Countryman (Apr 21, 1863): 1.

74 Joseph Addison Turner, "Our Purpose," The Countryman (Jul 26, 1864): 394.

75 Joseph Addison Turner, "Scarcity of Paper," The Countryman (Apr 21, 1863): 1.

${ }^{76}$ Joseph Addison Turner, "Rags," The Countryman (Apr 21, 1863): 18.
} 
sixteen full pages. Even more impressive, The Countryman ran without many hiccups in production.

Turner also urged newspapers and publishers to share much needed printing supplies. A ream of paper before the war was two dollars and fifty cents, but by March 1865 , it had increased to one hundred and fifty dollars. ${ }^{77}$ When supplies were depleted, Turner asked for assistance as he needed "some good brother printer" to sell or loan him the supplies needed as a special favor. ${ }^{78}$

The scarcity of resources did not always bring the periodical press together. Turner criticized editors who continued to print content that was old news or "standing matter." Editors, according to Turner, should only publish "living matter" and purchased advertisements. Most papers feared that any deviation from their current print format would negatively affect their readership and future subscriptions, but Turner believed readers considered any paper respectful as long as the content was worthy. ${ }^{79}$

Despite these challenges, Turner built a massive subscription base across the Confederacy. Even though The Countryman began one full year into war and competed with other fully established southern literary papers, its readership swelled into every Confederate state after six months. Turner bragged that he would have reached Missouri and Kentucky had it not been for the war. ${ }^{80}$ By December 1862, he prided The Countryman on having "a much larger circulation and is much more universally read in the county than any other paper taken in it." ${ }^{, 11}$ By 1863 , his initial thoughts on keeping his

\footnotetext{
77 Joseph Addison Turner, “A Convention of Editors,” The Countryman (Mar 28, 1865): 187.

${ }^{78}$ Joseph Addison Turner, “A Favor Wanted," The Countryman (Jun 17, 1862): 3.

79 Joseph Addison Turner, "Scarcity of Paper," The Countryman (Jun 17, 1862): 3.

${ }^{80}$ Joseph Addison Turner, "Third Volume," The Countryman (Sep 29, 1862): 1.

${ }^{81}$ Joseph Addison Turner, "The County Printing," The Countryman (Oct 13, 1862): 22-23.
} 
readership to a minimum had changed as Turner had loftier goals in mind: "Thousands of subscribers will not satisfy me. I want tens of thousands." He also expected to employ advertising and canvassing agents to further extend his readership. These actions placed The Countryman into every nook and cranny of the Confederacy. ${ }^{82}$ To expand subscriptions, amidst dwindling resources, however, Turner increased the price of the paper.

As publishers fought to secure material resources to meet their print schedules, many found the cost of supplies too great to bear. As a result, most resorted to shorter subscription periods and increased rates. Throughout the conflict, newspapers adjusted their subscription rates based on inflation, as well as the availability and cost of materials. The Countryman initially cost one dollar for an annual subscription, but by August 1862, the cost was the subscription rate plus fifty-two cents a year for postage. Paying one's subscription was only part of one's duty; paying the postage was the other. ${ }^{83}$ If a subscriber sent less, Turner deducted ten cents for postage to mail back the remainder. ${ }^{84}$ By the end of 1862, The Countryman cost two dollars annually, but had doubled in size. Over the course of the next two years, he implemented five additional price increases. By August 1864, The Countryman cost twenty dollars annually. ${ }^{85}$ Turner also published a notice called "Look Out for the X Mark" to remind his readers when their subscription was at its end ${ }^{86}$ For those who could not afford The Countryman, Turner provided

\footnotetext{
${ }^{82}$ Joseph Addison Turner, "Advertisements and other Matters," The Countryman (Feb 24, 1863): 70.

${ }^{83}$ Joseph Addison Turner, "Pay Postage," The Countryman (Aug 9, 1862): 3.

${ }^{84}$ Joseph Addison Turner, "One Dollar," The Countryman (Sep 6, 1862): 3.

${ }^{85}$ Joseph Addison Turner, "Increased Prices," The Countryman (May 3, 1865): 238.

${ }^{86}$ Joseph Addison Turner, "Look Out for the X Mark," The Countryman (Jan 31, 1865): 68.
} 
alternatives by allowing his readers to pay their subscription in rags, which offset the cost of the paper. ${ }^{87}$

As prices soared, Turner urged the southern literary press to develop a fixed price schedule of subscription and advertising fees for the duration of the war. According to Turner, a weekly paper should not earn less than four to five dollars annually without a loss to its owner. Many southerners considered the rising prices extortion and lambasted the press for increased rates. Turner argued that all editors, including himself are "fools about extortion in others, that they are afraid to now do anything that looks like extortion in themselves. They had better quit this nonsense (if they don't want to perish) and go to getting something like value received for their wares." In this view, providing a quality southern journal was not extortion; rather, it justified the cost, and subscribers should consider it a bargain. ${ }^{88}$

Material resources were not the only problem plaguing the southern print industry. A paper's staff faced the possibility of being drafted into the Confederate army. When the Confederate Conscription Act took effect in 1862, it originally exempted a number of occupations including editors, printers, and a portion of their staff. However as the war raged on, the number of available men to refill the empty ranks shrank. Towards the end of the war, exemptions were heavily scrutinized and sharply viewed as a means of avoiding military service. ${ }^{89}$ Arguing that a free press was the backbone of all southern liberties, Turner denounced the conscription of southern literary staff. Without it, the South would be despotic. Turner wrote, "it would be useless to send printers professedly

\footnotetext{
${ }^{87}$ Joseph Addison Turner, "Rags," The Countryman (Apr 21, 1863): 18.

${ }^{88}$ Joseph Addison Turner, “Another Editorial Convention," The Countryman (Mar 10, 1863): 86.

${ }^{89}$ Michael T. Bernath, Confederate Minds: The Struggle for Intellectual Independence in the Civil War South (Chapel Hill: University of North Carolina Press, 2010), 254.
} 
to fight for our liberties, were those liberties first destroyed by destroying the press.”

Instead, those men had a greater purpose to fulfill at home. ${ }^{90}$

Turner was exempt not only for his occupation, but also for his physical ailment. To publicly justify his own condition, he published a letter from a reader whose physical ailment also prevented him from serving in the Confederate army. The invalid feared public scrutiny because others were unaware of his handicap. Defending the man's plight, Turner argued that remaining at home did not end one's contribution to the war effort. $\mathrm{He}$ urged the invalid to care for other soldiers' women and children. Reporting to duty would only burden the war effort, most likely resulting in another wounded soldier or death. Those medical personnel and supplies would be better spent on able-bodied men who would return to duty. ${ }^{91}$ Since Turner acknowledged in one particular instance that he himself actually wrote many of the letters that appeared to be from his readers, one could question if Turner wrote this letter to provide an outlet to publicly explain his own physical limitations.

Towards the end of the war, the Confederate government lifted exemptions and sent conscription agents to the press offices across the South. ${ }^{92}$ The removal of exemptions, according to Turner, hurt the South's efforts to achieve intellectual independence by removing necessary personnel to write, print, and disseminate materials to southern readers. He ridiculed the Confederate conscription officers as they showed up in newspapers offices, knocked on the homes of the same men, and again they sent letters to the newspaper office asking for the same information for their redundant efforts in

\footnotetext{
${ }^{90}$ Joseph Addison Turner, "Silencing the Press," The Countryman (Sep 15, 1862): 2.

${ }_{91}^{91}$ Joseph Addison Turner, "Invalid's Letter," The Countryman (Apr 1, 1862): 2.

92 Joseph Addison Turner, "President's Message," The Countryman (Nov 22, 1864): 650-653.
} 
counting press staff. Turner worried that these men would be counted three times, inflating the number of available men. ${ }^{93} \mathrm{He}$ scoffed at the notion of sending the few men who maintained the liberty of the press at home off to war. ${ }^{94}$

As the war raged, the once-collaborative relationship between southern editors became combative due to the scarcity of materials, rising costs, and conscription. Accusations, personal quarrels, and complaints increased. ${ }^{95}$ One of the biggest complaints was that papers were plagiarizing from each other. Turner wrote, "There are two sinners against light and knowledge, where a willful plagiarism is perpetuated and published. The first is the man who commits the plagiarism and the second is he who commits it to print." 96 Turner attacked publishers who reprinted northern articles without proper citation as it was a despicable way to earn a living and became laughable to the North. For instance, when the Southern Punch reprinted an article from Graham's Magazine's November 1850 issue, the publisher alleged the republication was not plagiarism as the author received full credit during the initial publication; however, Turner held that someone's literary efforts should be recognized with every publication. ${ }^{97}$ In identifying these offenses, Turner was presenting himself to his readers as a well-read southern gentleman. ${ }^{98}$

\footnotetext{
93 Joseph Addison Turner, “The Number of Newspaper Men,” The Countryman (Nov 22, 1864): 1.

${ }^{94}$ Joseph Addison Turner, "President Davis and the Press," The Countryman (Jan 10, 1865): 8.

${ }^{95}$ Michael T. Bernath, Confederate Minds: The Struggle for Intellectual Independence in the Civil War South (Chapel Hill: University of North Carolina Press, 2010), 234.

96 Joseph Addison Turner, "Literary Papers in the South," The Countryman (Nov 10, 1863): 4.

97 Joseph Addison Turner, "Punch and Plagiarism," The Countryman (Dec 8, 1863): 1.

98 Joseph Addison Turner, "Etiquette or Exchange," The Countryman (May 5, 1863): 26. Southern publishers also exchanged papers as a professional courtesy. Turner, however, questioned the reciprocal relationship. He hoped that when daily and weekly newspapers sent copies that the difference would be paid to the newspapers. For example, when a weekly requested exchange with a daily, then it ought to enclose the amount of difference between its subscription price and that of the daily. The weekly had no right to expect an exchange of a paper costing more than it does. Common courtesy, Turner believed, should rule the print industry.
} 


\section{Conceiving a Native Literature}

The practical wartime obstacles of generating literary output were concrete issues that were handled as part of daily publishing operations. It was the abstract and visionary questions about the shape native southern literature would take that challenged cultural nationalists. In the end, southern literati focused on the development of a two-tiered print literature consisting of an immediate literature that raised awareness about the war and current events through the regular dissemination of news and information, and a more permanent inspirational literature that invoked pride and emotional attachment to the Confederate nation. Michael Bernath in Confederate Minds uses the terms "Literature of Knowledge" and "Literature of Power" to denote these two forms of literature, respectively. $^{99}$

To their credit, southern cultural nationalists successfully developed the infrastructure to create and disseminate news and information through newspapers and periodicals as it was quicker to produce and required less creativity than the more permanent literature. But they needed a reading audience. Previously, many southern readers had subscribed to northern papers as well as southern ones, but on a lesser scale. ${ }^{100}$ Turner and his literary press now faced the daunting task of cajoling the southern people to subscribe to their native newspapers and journals even as they were raising prices. He pleaded with his readers, "[I]s it not patriotic for you to...make the South independent in her literature, or she cannot be independent in anything else."101 Turner

\footnotetext{
${ }^{99}$ Michael T. Bernath, Confederate Minds: The Struggle for Intellectual Independence in the Civil War South (Chapel Hill: University of North Carolina Press, 2010), 80.

${ }^{100}$ Michael T. Bernath, Confederate Minds: The Struggle for Intellectual Independence in the Civil War South (Chapel Hill: University of North Carolina Press, 2010), 80.

${ }^{101}$ Joseph Addison Turner, "Southern Field \& Fireside," The Countryman (May 27, 1862): 4.
} 
also argued that a well-written newspaper was worth more than "the best school in twelve months." ${ }^{, 102}$ Through subscriptions, southerners had access to literary material to educate themselves, become well-informed Confederate citizens, and support southern print culture.

The periodical press struggled with the habit where readers shared their reading material with neighbors and friends as communal subscriptions hurt a publisher's pecuniary prospects. To shame communal readers, The Countryman reprinted an article ridiculing any decent man who did not purchase his own papers and journals. Any borrower was "a bad man" with "a screw loose in his organization." ${ }^{103}$ Subscriptions were invaluable in demonstrating the success of the southern literary movement.

The Countryman became an integral part of the southern dissemination of news; however, Turner altered his weekly journal in order to meet his readers' changing needs. While the daily newspapers primarily reported on local events and the progress of the war, weekly, monthly, and quarterly papers and journals like The Countryman focused on more editorials, poetry, serialized stories, political speeches, and satirical pieces. With unreliable casualty lists, constant troop movements, and erratic sources of information, most weekly papers did not have the space or time to devote to war news. The Countryman briefly reported war news in its first issues, but struggled to obtain timely information. By April 15, 1862, Turner's direction shifted to "relieve the minds of our people somewhat from the engrossing topic of war." ${ }^{, 104}$ War news was omitted until 1863

\footnotetext{
102 Joseph Addison Turner, "A Good Newspaper," The Countryman (Mar 25, 1862): 1.

${ }_{103}$ Joseph Addison Turner, "Newspaper Borrowers," The Countryman (Dec 15, 1863): 1.

${ }^{104}$ Joseph Addison Turner, "Prospectus," The Countryman (Apr 15, 1862): 4.
} 
when he decided to include it since most southern people could not afford multiple subscriptions. $^{105}$

In order to maintain their readership, southern editors struggled to fill the columns of their papers with worthy articles and information. A common antebellum practice had been to reprint articles from other news sources, both North and South, in order to fill column space. The war had forced southern editors to continue this process. While individually responsible for their own papers and journals, collectively their efforts fulfilled the immediate need for daily news. This shared approach served two purposes. First, it provided consistent messaging to their readerships that reinforced southern interests and loyalties. Second, it demonstrated the efforts of a united southern press. ${ }^{106}$

The southern press also occasionally printed reviews of each other's papers. Turner praised the newly published satirical Southern Punch for its important contribution to the literary movement when he wrote that the magazine was "a land-mark which clearly indicates the progress of our nationality. It is decidedly southern, and it is more than refreshing to see it so." ${ }^{107}$ Before the war, northern newspapers had dominated the country's print literature, including political satire that had a northern spin on issues that conflicted with southern views. Before this flourishing of Confederate magazines and journals, the South had never had the opportunity to satirize issues important to them.

Cultural nationalists also recognized the importance of creating news to preserve their history. Since the Confederacy did not begin until the outbreak of the Civil War, this was the fundamental starting point for Confederate history. Current affairs became a

\footnotetext{
105 Joseph Addison Turner, "Our New Prospectus," The Countryman (Aug 4, 1863): 1.

${ }^{106}$ Michael T. Bernath, Confederate Minds: The Struggle for Intellectual Independence in the Civil War South (Chapel Hill: University of North Carolina, 2010), 98.

107 Joseph Addison Turner, "The Southern Punch," The Countryman (Sep 15, 1863): 82-83.
} 
viable form of literature. As a result, news literature and native literature became one and the same. The Countryman's pages are littered with essays and poems about the Confederate government and its policies, the military victories and defeats, the horrors of the war felt both on the battlefield and the home front, and most significantly for Turner, patriotism and support of the Confederate war effort. ${ }^{108}$ Southern literati used the present and their future as an independent country to create a history for their nation. ${ }^{109}$ In "General Robert E. Lee," Turner wrote that the greatness of Robert E. Lee would lead to southern victory. ${ }^{110}$ "Gen. Lee as Commander-in-Chief" offered Confederate success through supplying the southern armies and the cessation of internal bickering. ${ }^{111}$ Turner's stories often fictionalized the war. "Bobbie and Georgie," for example, was about two children engaged in a playground fight. These children were Georgie (George McClellan) who was seen as a bully and Bobbie (Robert E. Lee) who defeated him. ${ }^{112}$ This story along with many others demonstrates Turner's belief that the South's ultimate victory as the underdog would eventually be secured.

With daily news being disseminated to its readers, the immediate literature had successfully flourished across the South. The more pressing goal of a lasting southern literature, on the other hand, would not be as easily achieved. While most cultural nationalists, including Turner, had sought a lasting southern literature long before the war, there had been minimal success. As Coleman Hutchison has shown, even northern

\footnotetext{
${ }^{108}$ Joseph Addison Turner, "The President and Leaders of the Confederate States," The Countryman (Nov 24, 1862): 68; Joseph Addison Turner, "The Confederate and Federal Finances," The Countryman (Jul 26, 1864): 396.

${ }^{109}$ James Reitter, "The Legacy of Three Southern Civil War Poets: Henry Timrod, Paul Hamilton Hayne, and Sydney Lanier," South Carolina Review, Vol. 41, Issue 1 (Fall 2008), 72.

${ }_{110}$ Joseph Addison Turner, "General Robert E. Lee," The Countryman (Oct 20, 1862): 29.

${ }^{111}$ Joseph Addison Turner, "Gen. Lee as Commander-in-Chief," The Countryman (Feb 28, 1865): 123.

${ }^{112}$ Joseph Addison Turner, "Bobbie and Georgie," The Countryman (Jul 26, 1862): 1.
} 
cultural nationalists anxiously awaited the South's pre-war contributions to the nation's literature. Cultural nationalists in the North and South hoped it would give birth to a new American literature encompassing all regions, inspiring the West, and give the South a regional identity. American cultural nationalists believed that for literature to be representative of the nation that it needed to reflect its many regions. ${ }^{113}$ As a result, the Civil War had forced its creation.

From the beginning, the Confederacy was, in the words of Hutchison, a "nation struggling to write itself into existence." ${ }^{, 114}$ Southern cultural nationalists had to catch up with the rest of the literary world by writing literature worthy of reading for generations to come. A lasting literature was to create a patriotic bond across the South, such as a poem about the joys of southern life or a novel that reflected on the greatness of southern society. More complex in nature, a lasting southern literature was to unite a distinct people to its culture and region and stir the hearts and minds of every southerner. ${ }^{115}$

But the southern literati had no prior experience or clear idea how to develop a lasting literature. Beyond being anti-northern and "truly southern," an elusive concept, most cultural nationalists failed to offer constructive requirements to aspiring southern writers. ${ }^{116}$ Like other cultural nationalists, Turner struggled to define the shape of southern literature. He made an attempt to capture the essence of what it meant to be southern in "The Old Plantation: A Poem," which was written by Turner in 1859 and

\footnotetext{
${ }^{113}$ Coleman Hutchison, Apples \& Ashes: Literature, Nationalism, and the Confederate States of America (Athens: University of Georgia Press, 2012), 27.

${ }^{114}$ Coleman Hutchison, Apples \& Ashes: Literature, Nationalism, and the Confederate States of America (Athens: University of Georgia Press, 2012), 3.

${ }^{115}$ Michael T. Bernath, Confederate Minds: The Struggle for Intellectual Independence in the Civil War South (Chapel Hill: University of North Carolina Press, 2010), 80.

${ }^{116}$ Michael T. Bernath, Confederate Minds: The Struggle for Intellectual Independence in the Civil War South (Chapel Hill: University of North Carolina Press, 2010), 98-100.
} 
published in The Countryman in 1862. Beginning in a nostalgic manner in which an old man returned to his childhood home, he wrote about the scenes surrounding the house as "my first affection and my last." Each line detailed his vivid memories with nature, wildlife and livestock, slaves and friends, and the changing seasons. While Turner's childhood recollections are rooted in southern plantation life, the poem itself appears problematic as it did not represent all of southern society, just the planter elite. Yet, Turner outlined in the preface that his poem was representative of the South as a whole. He believed that common sentiment could be found around the local scenery, manners, and customs. The idea of home was a "pleasant interest to everyone." He even argued that the name of the poem perhaps would have been better if called "The Old Home" or "The Deserted Homestead" that had a more general feel of a home regardless of locality. Recognizing that changing the name of the poem might have provided him with a larger audience, Turner "endeavored to sing of the southern home, instead of the home of the world." By also including slavery in the poem, he suggested that if a poem was representative of southern culture then it must "depict southern manners, customs, and institutions. I say, negro slavery is the south, and the south is negro slavery." Hoping to attract a southern audience beyond the planter, Turner used his own reminiscences to encourage love for southern culture. ${ }^{117}$

To further cultivate a native literature, Turner offered literary guidance to young writers. He encouraged writers simply to put their creative ideas and thoughts on paper. He wrote about an English author who earned a literary pension from the government by

\footnotetext{
${ }^{117}$ Joseph Addison Turner, “The Old Plantation: A Poem,” The Countryman (Oct 27, 1862): 36-37.
} 
writing his book initially on scraps of paper. ${ }^{118}$ Turner also encouraged publication. While he claimed that most writers were nervous about public rejections and harsh criticism, Turner urged southern writers to publish all of their work with the possibility of achieving great literary success. ${ }^{119}$

To further guide southern writers, Turner used well-known southern authors and poets, such as Henry Lynden Flash and Henry Timrod, as potential models. Flash was a southern poet, a Confederate soldier, and the editor and owner of the Daily Confederate newspaper in Macon, Georgia. Both Turner and his literary writer, Joel Chandler Harris, loved Flash's style in prose and compared him to Edgar Allan Poe and Alfred Lord Tennyson. Flash's poems spoke to his southern affection and support of the Confederacy. ${ }^{120}$ Henry Timrod, who was considered the poet laureate of the Confederacy, created poetry that inspired men to enlist in the Confederate army. Turner considered Timrod a poetic genius and frequently reprinted his works in The Countryman. ${ }^{121}$ Finally, Turner also promoted the works of southern poet James A. Russell because Russell held another occupation as an attorney while he wrote poetry. Turner's support of Russell's dual occupations was meant to encourage southerners in all posts to take up their pens in patriotic writing. ${ }^{122}$

Southern literati also used English and other European writers as examples for inspiring southern writers. Although Turner initially declared non-southern models did not belong in southern culture, he later encouraged the use of European models. Turner

\footnotetext{
${ }^{118}$ Joseph Addison Turner, "Peculiarity of an Author," The Countryman (May 8, 1866): 115.

${ }^{119}$ Joseph Addison Turner, "Discouragement of Authors," The Countryman (Oct 6, 1862): 13.

${ }^{120}$ Joseph Addison Turner, "Henry Lynden Flash," The Countryman (Jun 14, 1864): 1.

${ }^{121}$ Joseph Addison Turner, "Henry Timrod," The Countryman (Jul 26, 1862): 3.

122 Joseph Addison Turner, “James A. Russell," The Countryman (Jan 24, 1865): 40.
} 
condensed Dickens novels into serialized articles in which he discussed character development and plot lines. ${ }^{123} \mathrm{He}$ also celebrated great English poets like Chaucer and even King James I. ${ }^{124}$ Turner admitted that his purpose was to inspire southern literature, "by taking from the best English authors that the world's literature affords." "25 Crossing the English Channel, he also highlighted the works of M. Paul Feval and Voltaire claiming that French authors were far better than English ones as they "possess more life, vivacity, and genius." Comparing England and France geographically to the North and South, Turner argued that the French were a more southern and warm-hearted people and that the French literary greatness was closely tied to southern literary greatness. ${ }^{126}$

Although Turner struggled to define what it meant to be southern, he quickly latched onto the obvious institution of slavery. Throughout the antebellum period, northern writers, influenced by the Enlightenment and the anti-slavery movement, wrote against the slave labor system and the infringement upon personal freedoms. The North's literary culture antagonized southerners with abolitionist literature, most especially with Harriet Beecher Stowe's best-selling novel Uncle Tom 's Cabin. ${ }^{127}$ In response, southern writers went on the defensive by placing proslavery arguments at the center of their literary efforts. ${ }^{128}$ In March 1860, Turner published The Plantation, which dedicated its pages to the defense of slavery. Before the conflict, southern writers defended slavery in order to negate their opponent's arguments. But once the war broke out the proslavery

\footnotetext{
123 Joseph Addison Turner, "Hard Times," The Countryman (Mar 18, 1862): 1.

124 Joseph Addison Turner, "James I," The Countryman (Apr 29, 1862): 2.

125 Joseph Addison Turner, "Enlarging," The Countryman (Dec 22, 1862): 7.

126 Joseph Addison Turner, "Milton," The Countryman (Mar 28, 1865): 182.

${ }^{127}$ Randall Fuller, From Battlefields Rising: How the Civil War Transformed American Literature (New York: Oxford University Press, 2011), 9.

${ }^{128}$ Randall Fuller, From Battlefields Rising: How the Civil War Transformed American Literature (New York: Oxford University Press, 2011), 8-12.
} 
argument no longer required the same line of reasoning, debate, or validation. Southern writers wrote for a southern audience who shared the same interests in their society and institutions and embraced the proslavery argument. There was no longer a need to persuade readers or justify their arguments. In other words, they no longer had to be on the defensive; instead, the separation from the North allowed them to promote new forms of literary discourse that included slavery as a central theme. ${ }^{129}$

Creating their own native literature allowed cultural nationalists to ponder what new forms their literature should take. Coleman Hutchison argues that southern cultural nationalists embraced a variety of literary forms that could be linked to the pre-war years including forms that centered on ethnicity and race. ${ }^{130}$ For one, southern literature emphasized perceived ethnic differentiations between the North and the South. Southerners had prided themselves on being a distinct people detached from industry and capitalism. During the antebellum era, they also rooted this distinctiveness in each region's purported ancestry. Southern literati used what Ritchie Devon Watson has referred to as the "southern race mythology" to justify slavery and to elevate their own society above the barbaric northerners who were associated with their oppressive and tyrannical English Anglo-Saxon ancestors. Southerners viewed themselves as rulers in a feudal society tied to their aristocratic Norman ancestors. ${ }^{131}$

\footnotetext{
${ }^{129}$ Michael T. Bernath, Confederate Minds: The Struggle for Intellectual Independence in the Civil War South (Chapel Hill: University of North Carolina Press, 2010), 102-103.

${ }^{130}$ Coleman Hutchison, Apples \& Ashes: Literature, Nationalism, and the Confederate States of America (Athens: University of Georgia Press, 2012), 23.

${ }^{131}$ Drew Gilpin Faust, The Creation of Confederate Nationalism: Ideology and Identity in the Civil War South (Baton Rouge: Louisiana State University Press, 1988), 10-11; Ritchie Devon Watson, Jr., Normans \& Saxons: Southern Race Mythology and the Intellectual History of the American Civil War (Baton Rouge: Louisiana State University Press, 2008), 25-27.
} 
Other terms were also used to convey ancestry. Motivated primarily, but not exclusively, on Sir Walter Scott's depiction of medieval conflict between Normans and Saxons in Ivanhoe, southerners compared their relationship with northerners to that of Cavaliers to Roundheads. Southerners viewed themselves as the aristocratic Cavaliers. In contrast, southerners referred to northerners as "Yankees," who descended from fanatical Roundheads. It was this centuries old conflict between peoples about ethnicity that southerners believed defined their relationship with northerners in the decades prior to the war. $^{132}$

Throughout The Countryman, Yankee appeared dozens of times. Turner reprinted an article from the London Times, a southern sympathizing newspaper, which stated that the Cavalier South had "the highest reach of human thought. It is, therefore, the highest condition of mind to insure the rightful obedience to, and rightful control of, government." ${ }^{\prime 33}$ This characterization flattered southerners by representing them as a wise and cultured people that ruled another race for the benefit of southern society. This type of ethnic distinction fostered a literature that transcended socioeconomic classes amongst white southerners by appealing to both elites and ordinary folk. It also brought all southerners together under a regional heritage that excluded northerners and blacks. ${ }^{134}$

These attempts to create new and improved literary forms resulted in an outpouring of southern efforts with journals and periodicals being inundated with

\footnotetext{
${ }^{132}$ Ritchie Devon Watson, Jr., Normans \& Saxons: Southern Race Mythology and the Intellectual History of the American Civil War (Baton Rouge: Louisiana State University Press, 2008), 25-45.

${ }^{133}$ Joseph Addison Turner, "Puritans," The Countryman (Sep 29, 1863): 1.

${ }^{134}$ Drew Gilpin Faust, The Creation of Confederate Nationalism: Ideology and Identity in the Civil War South (Baton Rouge: Louisiana State University, 1988), 16.
} 
submissions from hopeful southern writers. ${ }^{135}$ The Countryman frequently requested submission, not only in hopes of building a new and original native southern literature, but to fill its pages. Yet very few writers, according to Turner, had the skill and style to be included in his weekly journal: "I frequently receive communications from different parts of the country which evince talent, but which are cast in a very rude moulding. It is useless to send me such articles. None but the very best in matter of style will be published." ${ }^{\text {"136 }}$ Most submissions, according to Turner, lacked polish, appeared amateurish, or were unworthy of publication; others fell short in their elaboration. ${ }^{137}$

While literary submissions poured in, Turner never praised nor published any submission outright. Rather, all submissions were subjected to his public criticism, critique, or total rejection. When a young Texas girl submitted her poem, Turner applauded its content and published it in The Countryman; but he questioned its originality. He believed the poem could have been plagiarized from the classics. ${ }^{138}$ While he easily accepted the literary worth of established, prominent southern authors and poets like Augusta Jane Evans and Henry Timrod, Turner was unable to identify potential new talent. Perhaps Turner lacked the creativity or imagination to recognize quality southern literature. Possibly he felt overwhelmed with the thousands of submissions or pressured by the importance of the task to locate talented southern writers. Turner had dreamed for so long of a native southern literature that it could be that he wanted only the very best to

\footnotetext{
${ }^{135}$ Michael T. Bernath, Confederate Minds: The Struggle for Independence in the Civil War South (Chapel Hill: University of North Carolina Press, 2010), 107-113.

${ }^{136}$ Joseph Addison Turner, "Vol. V.," The Countryman (Apr 7, 1863): 2.

137 Joseph Addison Turner, “To Correspondents and Others," The Countryman (Jun 17, 1862): 3.

138 Joseph Addison Turner, “A Gem,” The Countryman (Mar 21, 1865): 169.
} 
be included. Unfortunately, he never divulged his reasons in either his personal journal or in The Countryman.

What is evident was Turner's critical eye in criticizing or rejecting almost every submission that made its way to The Countryman. He wrote that one poem was "hardly up to the standard which we have erected for The Countryman." Another was, according to Turner, "brimful of patriotism and true womanly feeling, but had not been elaborated to that high degree of polish." ${ }^{\prime 139}$ Sometimes Turner declined an author's work with one line rejections: "My Childhood's Home' is respectfully declined." ${ }^{140} \mathrm{He}$ also criticized submissions for their typographical errors and mercilessly proofed their work. ${ }^{141}$ Turner explained perfection sometimes meant taking away and not adding more as the author "employ[ed] too much language to convey their ideas."142

Struggling to identify worthy material and perhaps believing that he himself epitomized the best in southern literature, Turner published his prior literary work penned under non de plumes, such as Peter Pickle, Anti-Jacobin, Uncle Jimmy, and Aunt Sally Poke to give the impression that many different people contributed to The Countryman. When a reader questioned the authenticity of "Dorothy's Letter," Turner confessed that he himself wrote some of the letters actually published from his readers, but never revealed which ones. ${ }^{143}$ Turner most likely found the new literature lacking so he fell back on what he recognized as quality writing, his own work.

\footnotetext{
139 Joseph Addison Turner, "To Correspondents," The Countryman (May 6, 1862): 2.

140 Joseph Addison Turner, "My Childhood's Home," The Countryman (Mar 24, 1863): 1.

${ }^{141}$ Joseph Addison Turner, "The Trials of a Soldier's Wife," The Countryman (Oct 18, 1864): 577.

142 Joseph Addison Turner, "Writers - Perfection," The Countryman (Jan 19, 1863): 29; Joseph Addison Turner, "To a Young Correspondent," The Countryman (Oct 27, 1862): 40.

${ }^{143}$ Joseph Addison Turner, "Dorothy's Letter," The Countryman (Apr 15, 1862): 1.
} 


\section{The Failure of Confederate Print Literature}

The crux of the cultural movement was the struggle to create a permanent and superior literature. Cultural nationalists had to weed through thousands of literary submissions finding, as they claimed, few of merit. Most literature represented a particular event in the war or their surroundings, which many concluded had little endurance beyond the present. While many works were passionate, emotional, and patriotic, most lacked the ability to endure. And none provided adequate justification of slavery that negated the opposition.

By 1863, it became obvious that a lasting native literature was not going to be created during the war. Cultural nationalists recognized that southern literati were still writing as they did when the South was part of the United States. Their literature expressed a regional tone that placed the South, not as an independent nation, but as a part of a greater whole and competing for interests in a larger nation. Perhaps it was a challenge to transition from the pre-war writing style or to write without thought of outside influences or competing interests. As a result, southern writers failed to write for a nation fighting for autonomy, influenced by no other, and completely self-sufficient. Cultural nationalists, including Turner, realized that this great task would have to be left to future generations who grew up in an independent Confederacy. The next generation would not dwell on the importance of writing about a regional identity; instead, they would focus on a national and international identity that would place the Confederacy amongst other nations with inspiring native literatures. ${ }^{144}$

\footnotetext{
${ }^{144}$ Michael T. Bernath, Confederate Minds: The Struggle for Intellectual Independence in the Civil War South (Chapel Hill: University of North Carolina Press, 2010), 212-217.
} 
Turner openly admitted the South's literary failures: "Literature has her quacks no less than medicine, and they are divided into two classes - those who have erudition without genius, and those who have volubility without depth. We shall get second hand sense from the one, and original nonsense from the other." ${ }^{145} \mathrm{He}$ published the sentiments of southern literary author Charles L. Wheeler, who advised his fellow literati not to publish anything "literary; don't be patriotic," and if anyone felt the insatiable need to write then they should instead, "cut your fingers off."146

The Countryman had been a strong advocate for an intellectually autonomous nation, but Confederate defeat dramatically altered its literary tone. It was as if Turner was going through the stages of grief or mourning as his writings exposed dismay, anger, depression, and outright denial. In one article he supported a Confederate nation with no thoughts of rejoining the Union; yet in another, he expressed defeat, but reconciled himself to embrace the United States as it was before the war with slavery and the right to secede intact. ${ }^{147}$

Turner mourned the loss of a separate political and intellectual southern nation along with the freedom of the press. He considered southern occupation by federal troops a form of tyranny and despotism. Turner no longer believed he had the liberties as an editor as he did under the Confederate government. To express his discontent with the end of the Confederacy, The Countryman's motto, "Independent in Everything. Neutral in Nothing," changed to "Independent to Nothing, Neutral in Everything.” Beginning with the June 6,1865 issue Turner felt that retaining the old motto "under the present

\footnotetext{
${ }^{145}$ Joseph Addison Turner, "Literature has her quacks," The Countryman (Mar 1, 1864): 101.

${ }^{146}$ Joseph Addison Turner, "Literary Reminiscences," The Countryman (May 10, 1864): 266.

${ }^{147}$ News of the southern surrender was not immediate. While surrender occurred on April 9, 1865, Turner did not comment on their defeat until the May 2, 1865 issue.
} 
circumstances, would be to keep a living lie flying at our mast-head. Therefore we strike our old colors, and run up new ones more congenial to the times."148 Additionally, Turner wrote, "If I cannot edit a paper as a freeman, I will edit none at all." He equated southern defeat and the impeding reconstruction of the Union to northern bondage where he felt the "weight of the chains I have to wear." Under literary control by the southern occupying federal military, Turner insisted on publishing only quarter sheets, but promised to return to full sheets after he learned of the "regulations my masters make concerning the press." By projecting himself in bondage, Turner depicted himself and other southern cultural nationalists as slaves bound to the rules, regulations, and demands of the North. ${ }^{149}$

Frustrated by defeat, The Countryman frequently published hostile demands towards the Union and its occupying army by instructing them on the proper course of affairs. In one breath, Turner defended the southern cause and remained loyal to the Confederacy; in the next, he lamented that southerners were a conquered people. He accused the North of wielding power over the South, but recognized no other alternative. Turner admitted that any further resistance was useless, but if there was a chance to resist he supported it. Defeated, proud, and forever hopeful, Turner's words revealed the anguish of many southerners. ${ }^{150}$

If the Confederacy failed to achieve political independence, it also failed in achieving intellectual independence. Yet, the southern cultural movement was partially successful. Southern literati could boast a robust infrastructure, a vast and impressive

\footnotetext{
148 Joseph Addison Turner, “Our New Motto,” The Countryman (Jun 6, 1865): 296.

149 Joseph Addison Turner, “To my Patrons," The Countryman (May 9, 1865): 277.

${ }^{150}$ Joseph Addison Turner, "The Proper Course," The Countryman (May 16, 1865): 281.
} 
collection of newspapers and journals, and much literature although its quality continues to be debated today. What southern cultural nationalists believed was their failure to develop an enduring literature, scholars have since recognized as significant contributions to southern wartime literature. The goal to impress the world might have been unsuccessful in 1865 , but today that literature paints a different picture. ${ }^{151}$

In July 1865, Turner reflected on the aftermath of the intellectual movement in his journal: "The most galling tyranny ever endured by mortals afflicts the southern people. Anarchy and tyranny, twin demons, reign supreme. I did all I could to show them what would be their fate as a conquered people. I thought that our people, properly united, might have accomplished the desires of our hearts." ${ }^{, 152}$ The loss of the Confederacy represented the end of Turner's long literary career advancing southern culture and literature. He briefly continued The Countryman, but returned to the pre-war practices of publishing northern articles, using northern publishing houses, and resuming those professional relationships necessary to conduct business in the Union. ${ }^{153}$ The Countryman had once been called the "little gem" of the Confederacy, but by May 1866 Turner closed the journal down. ${ }^{154}$

${ }^{151}$ Coleman Hutchison, Apples \& Ashes: Literature, Nationalism, and the Confederate States of America (Athens: University of Georgia Press, 2010), 2.

${ }^{152}$ Autobiography of Joseph Addison Turner, Robert Woodruff Library Microforms. Emory University, Emory, Georgia, July 9, 1865.

${ }^{153}$ Joseph Addison Turner, The Countryman (May 8, 1866): 116.

${ }^{154}$ Joseph Addison Turner, "To Correspondents and Others," The Countryman (Jul 19, 1862): 2. 


\section{CHAPTER III}

\section{RELIGION}

In the decades before disunion, the three main evangelical Protestant denominations - Methodists, Baptists, and Presbyterians - sought to further Christianize Americans. The 1830s saw the apex of the Second Great Awakening when evangelical revivals challenged the old Calvinist doctrines of pre-destination, limited atonement, and original sin by ushering in a new liberal Christianity that emphasized love, charity, and God's benevolence for the masses as opposed to the select Calvinist few. Leaving behind the traditions of authority, position, and status, evangelicalism provided common, ordinary Americans with the mechanism to change the way in which religion shaped their society and culture. ${ }^{155}$ In these ways, evangelicalism acted as a public religion wherein a national Christian community that transcended denominations emerged. ${ }^{156}$

This public religion, or national civil religion, was not centered around public worship, but rather was devoted to a set of moral principles, such as the recognition of God's influence in all things, reward for their virtue, and punishment for sinful behavior, that would guide Americans in their daily lives. Similarly, Turner applied that same ethos to his own version of southern civil religion that can be read The Countryman's pages, but used it to uphold southern culture and society. Just as the American civil religion was

\footnotetext{
${ }^{155}$ Nathan O. Hatch, The Democratization of American Christianity (New Haven: Yale University Press, 1989), 35-40.

${ }^{156}$ Paul Johnson, A Shopkeeper's Millennium: Society and Revivals in Rochester, New York, 1815 1837 (New York: Hill and Wang, 2004), 4-5.
} 
built as a national cultural representation of both virtue and liberty by connecting individuals to their nation through their religious devotion and linking their relationship to God through the nation's rituals and symbols, Turner employed his southern civil religion to build a devout, yet secular community of white southerners that upheld the racially structured social hierarchy and supported their cultural institutions, especially slavery. ${ }^{157}$

The evangelicalism of the Great Awakening, however, was integrated into northern culture and southern culture in different ways. Religious leaders in both the North and South used revivals to reach as many people as possible in order to promote individual salvation, a personal obligation to understand and live according to the Bible, and build a morally rich relationship with God. ${ }^{158}$ The chief difference was in the social structures that revivalism supported. Northern churches sought a religious community based on shared experiences and inclusion of all social classes and genders. ${ }^{159}$ Southern churches, on the other hand, supported a hierarchical social order based on white patriarchy. The greatest clash, though, was over biblical interpretations of slavery. Many northern churches viewed slavery as a national sin. While the various denominations in the North debated over the various biblical interpretations of slavery, all agreed that slavery was immoral and evil. Southern churches, on the other hand, universally viewed

${ }^{157}$ Robert N. Bellah, "Civil Religion in America," The Journal of the American Academy of Arts and Sciences, Vol. 96, No. 1 (Winter 1967), 2-8.

${ }^{158}$ Mark A. Noll, The Civil War as a Theological Crisis (Chapel Hill: University of North Carolina Press, 2006), 2, 18-19.

${ }^{159}$ Paul Johnson, A Shopkeeper's Millennium: Society and Revivals in Rochester, New York, 1815 1837 (New York: Hill and Wang, 2004), 4. 
slavery as a morally good and benevolent system. Southern churches thus offered religious sanction to the white southern order. ${ }^{160}$

The ways in which evangelicalism was integrated differently into northern and southern cultures were indicative of a growing strain within the national religious organizations. By the mid-nineteenth century national unity among those national governing bodies had given way to discord. By the 1840s, slavery had created a schism that divided the denominations into regional blocs. Southern religious leaders, who had become a minority at national conferences, viewed northern majority rule as tyrannical and misrepresentative of southern religious views, especially slavery. In addition, northern anti-slavery sentiment provoked southern religious leaders to openly defend their way of life.

Although the three primary evangelical denominations were organized differently at the national level, each broke into sectional churches, split geographically into northern and southern regional blocs through which they developed their own religious views on slavery. These splits were significant because they set the precedent that national disunion was possible. ${ }^{161}$ In 1837 , Presbyterians became the first of the three denominations to splinter into two factions: the Old School that appealed to the southern regional bloc, and the New School that aligned to the views of the northern regional churches. The Methodist General Conference, their national governing body, separated in 1844 into two general conferences. The southern Methodists formed the Methodist Episcopal Church in May 1845. Finally, the Baptists national governing organization

\footnotetext{
${ }^{160}$ Christine Leigh Heyrman, Southern Cross: The Beginnings of the Bible Belt (Chapel Hill: University of North Carolina Press, 1997), 11-27.

${ }^{161}$ C.C. Goen, "Broken Churches, Broken Nation: Regional Religion and North-South Alienation in Antebellum America," Church History, Vol. 52, No. 1 (Mar 1983), 22-24.
} 
known as the Home Missionary Society witnessed a mass exodus by southern Baptists, who subsequently formed their own Southern Baptist Convention in May $1845{ }^{162}$

Joseph Addison Turner was characteristic of this larger national story. This chapter illustrates how Turner used his brand of faith to develop a southern civil religion out of the remnants of evangelical Protestantism's national civil religion. He subscribed to the nineteenth century liberal Christianity that emerged from the Second Great Awakening by developing, what Turner called, a practical religion based on the tenets of post-Calvinist Christianity including universal love, charity, and compassion. Turner defined his practical religion as one that followed "The Character of our Savior," which focused on the ways in which Jesus led his life, his principles and religion, along with "his humility, his goodness, his compassion for suffering humanity, his submission to ill treatment, his love of his enemies, and his self-denial."163 Turner merged some of these liberal Protestant views with southern religious values by using these ideas of love, charity, virtue, and sacrifice to urge southerners to support both slavery and the war effort.

Turner was not affiliated with any religious denomination nor did he follow any established religious doctrines or practices, but this did not make him an atheist. He believed in the goodness of Christianity and the importance it played in one's life. In fact, Turner condemned atheists as "the most miserable of beings" without a heavenly father to guide them. While he agreed with atheists that churches needed to be reformed, Turner

\footnotetext{
${ }^{162}$ C.C. Goen, Broken Churches, Broken Nation: Denominational Schisms and the Coming of the American Civil War (Macon: Mercer University Press, 1985), 65-67, 127; George C. Rable, God's Almost Chosen People: A Religious History of the American Civil War (Chapel Hill: University of North Carolina Press, 2010), 15-16, 22-26.

${ }^{163}$ Joseph Addison Turner, “The Character of our Savior,” The Countryman (Mar 27, 1866): 70.
} 
added that reform could not be accomplished without the grace of God and religious tolerance. ${ }^{164}$ His 1863 article in The Countryman entitled "Atheism" called for the atheists to open their eyes and bear witness to God's works and learn about His word. Turner explained God's existence as, "He who creates all things, himself must be uncreated, existing in infinite majesty, living in the eternity of his own nature, reigning in the plentitude of his own omnipotence, forever sending forth the word which creates, supports, and governs all things."165 Turner was a Christian who viewed God as an abstract concept, and his religious views transcended denominational differences. More importantly, he constructed a religious ideology that upheld the southern social structure. $^{166}$

Although his faith was rooted within northern evangelical Protestantism, Turner used it to build a southern national civil religion. Turner's southern civil religion was a public religion for the Confederacy that encompassed the devotion of white Christian southerners through a commonly held set of beliefs, rituals and symbols, including fasting and prayer days, the Confederate seal, and charitable support for the poor and needy. Turner's civil religion can be read throughout the pages of The Countryman, as he denounced sectarian differences, advocated southern virtue, condemned sinfulness, recognized God's purpose in sacrifice and suffering, and reminded southerners that they were God's chosen people. Turner used The Countryman to influence devotion, not only to God, but also to their southern cause. Devotion to the Confederacy, according to Turner, was both secular and sacred and it encompassed every aspect of southern life.

\footnotetext{
164 Joseph Addison Turner, “Atheist,” The Countryman (Jun 2, 1863): 41.

165 Joseph Addison Turner, “Atheism," The Countryman (Jun 20, 1865): 302.

${ }^{166}$ Autobiography of Joseph Addison Turner, Robert Woodruff Library Microforms, Emory University, Emory, Georgia, 21-26.
} 
The Folly of Fanaticism

During the Second Great Awakening, evangelicals used revivals as the primary method of salvation. Social prayer lay at the heart of evangelicalism. While conversion, prayer, salvation, and redemption were once powerfully private matters, the emergence of revivals transformed them into intensely public and social events. ${ }^{167}$ According to the Methodist circuit rider Peter Cartwright's writings in the early 1800s, revivals were a place where "hundreds fell prostrate under the mighty power of God, as men slain in battle." Revivals represented, in many cases, the only religious outlet for people living outside urban areas. With a pulpit, an altar, several preachers, and thousands seeking God's forgiveness, a large country field or few acres of land became transformed. People from miles around packed up their food and supplies for these multi-day religious events. Preaching went on hour after hour well into the night and early morning. Praying, singing, shouting, and weeping were heard in every corner of the camp meeting. Afterward, ministers bragged about the number of proselytes, often inflating not only the number of saved souls, but also their egos. ${ }^{168}$

In the spring of 1839 , Turner was the tender age of thirteen when he experienced his first revival at the Philadelphia Methodist Church near his home in Eatonton, Georgia. As he recounted in his personal journal, on the first day of the revival the entire family attended, except for Turner. Upon their return, the family's overseer Archibald Davis described to him the day's activities including the conversion of many of Turner's school friends. He condemned his associates as he believed them to be too young to participate.

\footnotetext{
${ }^{167}$ Paul Johnson, A Shopkeeper's Millennium: Society and Revivals in Rochester, New York, 1815 1837 (New York: Hill and Wang, 2004), 96-97. 34.

${ }^{168}$ Autobiography of Peter Cartwright, ed. Charles L. Wallis (Abingdon: Abingdon Press, 1984), 33-
} 
Nonetheless, on the Sunday of the revival, Turner attended in order to witness it firsthand. There, he found himself caught up in the excitement with the rest of the congregation. When mourners were invited to the altar, Turner was drawn to it with several other children "in paroxysms and convulsions of groans, tears, and shouts." ${ }^{169}$ It did not end there. Turner was in a state of "languor and lassitude" when he passed out. Carried into a tent and surrounded by his family and preachers, he shouted, then lay lethargic until the cycle started again. Turner wrote that, "During my intense excitement my muscles and ligaments became so cramped that for a little while convulsions would have been the result." 170

After Turner's conversion, his parents, friends, and fellow parishioners encouraged him to further seek out his religion. However, Turner noted that he was ashamed of his conversion and appalled by his emotional reaction, which he termed the “folly of fanaticism." ${ }^{171}$ By reading Turner's personal journal entries, one can immediately deduce his opinions not only towards revivals, but denominational faith in general. Turner, for example, noted his dislike of preachers calling them the "greatest fanatics" he ever met. He also challenged the insecurity of the children who attended the altar with him that day. While Turner recognized the emotional frenzy that caused his conversion, he understood that others too were easily fooled and were unable to see the conversion for the folly it really was. He claimed they were compelled by the preacher's threat of hell and damnation if they failed to repent and convert. Turner, on the other

\footnotetext{
${ }^{169}$ Autobiography of Joseph Addison Turner, Robert Woodruff Library Microforms. Emory University, Emory, Georgia, 21-26.

${ }^{170}$ Autobiography of Joseph Addison Turner, Robert Woodruff Library Microforms. Emory University, Emory, Georgia, 21-26.

${ }^{171}$ Autobiography of Joseph Addison Turner, Robert Woodruff Library Microforms. Emory University, Emory, Georgia, 21-26.
} 
hand, confessed that he had no fears of hell or eternal damnation. Instead, he claimed that he approached the altar out of sympathy to the others who experienced anguish and moral dilemmas. Yet, Turner announced his self-proclaimed sympathy in hindsight. He must have realized the emotional excitement it stirred in him as it did in the others. ${ }^{172}$

Soon after, at the age of fourteen, Turner renounced his faith in Methodism. He rejected the Methodist dogma and adopted what he called "more liberal religious views." Unfortunately, he remained under his father's charge and was required to perform his familial religious duties. But by nineteen years old, Turner "threw off the yoke" and officially withdrew his membership from the Methodist Church. ${ }^{173}$ Turner found denominational religion caused more harm than good amongst its believers by focusing on specific practices and rites, instead of teaching Christian morals and faith in God. For example, he wrote in his personal journal that "[I] looked upon repentance as an instrument of torture by whose castigation we are to merit salvation; I regard it as simply a change from good to bad." ${ }^{\prime 14}$ Turner believed religion was not a supernatural occurrence whereby men and women suddenly have a positive change of heart. Instead, he understood it to be a partnership with God to cease doing evil and live by the tenets of the Bible. Religion was a principle or rule on which to base one's life. It was a guiding compass that led to a positive and fulfilling life. Denominational religion, on the other

\footnotetext{
${ }^{172}$ Autobiography of Joseph Addison Turner, Robert Woodruff Library Microforms. Emory University, Emory, Georgia, 21-26.

${ }^{173}$ Autobiography of Joseph Addison Turner, Robert Woodruff Library Microforms. Emory University, Emory, Georgia, 21-26.

${ }^{174}$ Autobiography of Joseph Addison Turner, Robert Woodruff Library Microforms. Emory University, Emory, Georgia, 21-26.
} 
hand, was based on tracts and rituals that claimed to save souls, which Turner denounced. ${ }^{175}$

In addition, Turner disagreed with denominational preaching that shamelessly displayed a minister's learning, preached for the sake of controversy against other denominational creeds, or preached simply to obtain proselytes. For Turner, these types of preachers were hardly righteous. He argued that preachers did not need to secure converts to spread the word of God, nor did they have to preach to convince converts that their creed was the correct path to salvation. Instead, ministers should teach from the moral lessons of the Bible and tolerate other beliefs that were different from their own. The Bible, the same book used by all Protestant denominations, should teach the same moral lessons of charity, tolerance, and universal love to all white Christian southerners. ${ }^{176}$

\section{Turner's Religiosity}

Turner's religiosity made him very much a part of the liberalization of Christianity in the nineteenth century. However, his application of those liberal beliefs was contradictory. For example, Turner claimed to believe in religious tolerance, but upon closer review, he was not so tolerant. Although his faith transcended denominations, Turner specifically meant tolerance of other Christians. Tolerance was also restricted to the white southern population. To illustrate his beliefs, Turner reprinted an article from the Christian Index that spoke of the notion of slavery and Christianity. It read: "If slavery be not of God, then we are fighting against Him, and our cause will fail:

\footnotetext{
${ }^{175}$ Autobiography of Joseph Addison Turner, Robert Woodruff Library Microforms. Emory University, Emory, Georgia, 21-26.

${ }^{176}$ Autobiography of Joseph Addison Turner, Robert Woodruff Library Microforms. Emory University, Emory, Georgia, 55-56.
} 
if it be of God, then our enemies are fighting against Him and we are for Him and Truth: and 'if God be for us who can be against us?",177 Turner believed that the South must be confident that slavery was sanctioned by God. If southerners compromise their beliefs in slavery and God, then, according to Turner, God will not allow the South to win the war. Therefore, Turner's southern civil religion focused strictly on building a virtuous white Christian southern nation. His religion sought to preserve the southern Christian tradition without modifying the existing social order. ${ }^{178}$

Turner's religion thus did not cleanly fit the model of religion in either North or South at that time. While both northern and southern churches had some similarities, including using religion to control society, increasing female converts, and using revivals as their instrument to increase church memberships, each section went about it differently. There was a democratization of religion in the North that used Christian soldiers to encourage reform and activism across all of society. Men and women actively participated in organizations, such as anti-slavery groups and temperance organizations, whose mission was to morally improve northern society. It was their collective effort that brought God's blessing. ${ }^{179}$ While the southern Christians sought to maintain the status quo; their faith was deeply rooted with a deep conservative Christianity. The pro-slavery rhetoric within southern churches reinforced the authority of God and southern white men by preaching civil obedience and submission of wives and slaves to husbands and

\footnotetext{
177 Joseph Addison Turner, "Slavery," The Countryman (Mar 29, 1864): 162-163.

${ }^{178}$ Christine Leigh Heyrman, Southern Cross: The Beginnings of the Bible Belt (Chapel Hill: University of North Carolina Press, 1997), 11-18.

${ }^{179}$ Paul Johnson, A Shopkeeper's Millennium: Society and Revivals in Rochester, New York, 1815 1837 (New York: Hill and Wang, 2004), 118.
} 
masters. ${ }^{180}$ Turner's southern civil religion embraced the idea of activism of the North, but not in the form of reform organizations. Rather he encouraged the goodwill of all southerners to support the Confederate war effort and southern society by aiding their neighbors, communities, and country in their everyday lives. Turner's civil religion was based on the principle that devotion to God could be furthered through the devotion to the Confederacy.

Moreover, for Turner, religious unit across denominations was crucial to sectional unity: "My object is to get Christians to stop quarrelling about minor matters, and with united effort give their energies and resources to the grand cardinal principle taught by Christ - universal love and brotherhood,." he enthusiastically wrote. ${ }^{181}$ It was this concept of a united religious front that Turner believed designated the Confederacy as a southern Christian republic. He condemned the notion that religious creeds or one denomination had the ability to unite southerners. Rather, he believed southerners achieved moral excellence when guided by God throughout their daily lives. In this way, he believed that southern virtue transcended dogmas and denominations. ${ }^{182}$

Turner used The Countryman to forge religious unity in order to foster this southern civil religion. He held that God's reward of an independent southern nation hung in the balance. As this chapter reveals, Turner wrote about topics that kept southern virtue and God's approval on the minds of his readers. From participating in important national fasting and prayer days, accepting death and sacrifice as part of God's divine

\footnotetext{
${ }^{180}$ Stephanie McCurry, Masters of Small Worlds: Yeoman Households, Gender Relations, \& the Political Culture of the Antebellum South Carolina Low Country (Oxford: Oxford University Press, 1995), 177-181.

${ }^{181}$ Joseph Addison Turner, "Brother Wood," The Countryman (Dec 1, 1862): 2.

182 Joseph Addison Turner, "Practical Religion," The Countryman (Apr 7, 1863): 4.
} 
plan, denouncing extortionists, and performing charitable acts that helped southerners and the southern cause, Turner's broad-based Christianity applied to all southern people and was meant to fulfill God's divine plan of securing southern independence. His ideas of practical and civil religion embraced God, the Bible, and a patriotic duty to the Confederate nation through Christian fellowship, charity, and tolerance within their southern white society.

\section{Sectional Discord}

The religious fracturing of the national religious organizations over the issue of slavery created an illusion that disunion was easily achievable. The abolitionists and northern clergy who supported the anti-slavery crusade believed that slavery was immoral on religious grounds and corrupted the essence of Christianity. These beliefs set southern church leaders on the defensive. If the northern churches initiated the slavery debate through moral and religious arguments, then southern churches had to defend their institution in the same manner; otherwise, the southern defense of slavery appeared immoral. As a result, southern clergy saw themselves as the first line of defense in arguing that slavery was scripturally sanctioned. Also, as mentioned earlier, southern churches held the minority in the national religious organizations. Church leaders believed the northern majority would not support southern interests. Slavery was not a national institution. The South's heavily reliance on slave labor and the absence of slavery in the North only increased sectional tensions and animosity. With no acceptable solution or compromise, southern church leaders felt they had no other recourse, but to 
disband. In the end, both North and South felt they could fulfill God's plan for a Christian republic alone, without the other. ${ }^{183}$

The division had appeared easy. The splintering of the national churches was peaceful in the sense that both northern and southern churches were able to exist outside of the national organizations without any repercussions to their local congregations or regional leadership. Southern church leaders applied their version of states' rights to their departure and perpetuated the idea that national disunion also could easily happen. They held that the evangelical churches who had joined the national religious conferences did so voluntarily; therefore, they could exit as easily as they entered. These leaders also believed that converted people made up a church in the same fashion that people made up a state. They could simply move to another state or join a different church. However, in reality, the civic disunion of the nation was not as easy. Few, if any, realized or deemed it critical to the disunion question that churches were private entities, not public institutions. While churches could easily be closed down and new ones created, the federal nation was not as easily dismantled. Finally, churches were brick and mortar buildings that were available to people within a specific geographical area. The nation, on the other hand, encompassed all regions within its borders and constituted a larger entity than a local congregation. $^{184}$

Still, since slavery continued to fester on the national political stage, southern politicians promoted the notion that national disunion was a viable solution. Specifically, the expansion of slavery was the crux of the matter. Northern politicians sought to stop

\footnotetext{
${ }^{183}$ C.C. Goen, Broken Churches, Broken Nation: Denominational Schisms and the Coming of the American Civil War (Macon: Mercer University Press, 1985), 65-67, 127.

${ }^{184}$ C.C. Goen, "Broken Churches, Broken Nation: Regional Religion and North-South Alienation in Antebellum America," Church History, Vol. 52, No. 1 (Mar 1983), 27.
} 
the spread of slavery into new territories while southern politicians wanted territorial expansion of their peculiar institution. Politicians realized that if political compromise over the slavery issue was unreachable then disunion could be replicated at the national level. $^{185}$

\section{God's Divine Plan}

Most nineteenth century Americans witnessed God's interventions in all aspects of their lives from the birth of a child, the death of a loved one, sickness and disease, a drought that devastated crops, an abundant harvest, or any type of natural disaster such as flooding, tornadoes, and storms. God's approval delivered joy and happiness. His disapproval brought death and destruction. Above all else, Americans saw God as sovereign. Not only did He influence citizens' daily lives, but He was instrumental in the overall stability of the nation. ${ }^{186}$

When southerners announced that the American experiment had failed, they viewed disunion as a sign of God's favor. The nation's health had depended upon the Christian faith and actions of its citizens, but southerners argued that northerners' many sins, especially their opposition to slavery, hindered the nation from moving forward. The United States had failed to become a true Christian republic. While Turner's brand of civil religion supported the concept of activism, he found northern attacks against slavery as assaults upon their southern character and religion. Southerners could no longer, in

\footnotetext{
${ }^{185}$ C.C. Goen, Broken Churches, Broken Nation: Denominational Schisms and the Coming of the American Civil War (Macon: Mercer University Press, 1985), 13-15.

${ }^{186}$ Mark A. Noll, The Civil War as a Theological Crisis (Chapel Hill: University of North Carolina Press, 2006), 84-86.
} 
good conscience, remain in a nation where their interests were not considered a part of the larger vision of the national community. ${ }^{187}$

In The Countryman, Turner differentiated the South from the North in religious terms for his readers. He explained that the North was a "God-defying, God forsaken" nation submerged in corruption and despotism. ${ }^{188}$ He lamented that there was a time when southerners dreamed of a union reaching from ocean to ocean and the Great Lakes to the mouth of the Mississippi, but the North did not allow it. Turner denounced the North's disregard of the law, the Constitution, and more importantly, the Bible. Furthermore, the southern people were utterly powerless in reversing northern depravities. Turner, like most southerners, believed this to be part of "God's mysterious way' as it was seen as an omen that a united nation was going against God's divine purpose. ${ }^{189}$ These actions caused God's divine power to dissolve the union. As he wrote in 1864, "It is His will that the south should never again be united to the north."

In order to demonstrate God's hand in disunion, Turner reminded his subscribers that George Washington initially opposed any separation from England, but providence won in the end. With secession, the South faced a similar situation. God had willed the southern people to separate from the North to create their own Christian republic. Revolution had made Washington an American. Therefore, disunion had turned southerners into Confederates. This assertion of righteousness reinforced the notion of God's divine hand guiding the southern people to make the decision to secede and squarely placed God on their side.

\footnotetext{
${ }^{187}$ Paul Quigley, Shifting Ground: Nationalism and the American South 1848-1865 (Oxfor5d: University Press, 2012) 20, 59, 66-67.

${ }^{188}$ Joseph Addison Turner, "Republics vs. Monarchies," The Countryman (Dec 1, 1863): 1.

${ }^{189}$ Joseph Addison Turner, "The Result," The Countryman (Jun 7, 1864): 7.
} 
In 1863, Turner reminisced on the issue of secession by reaffirming the connection between secession and religion. Secession was not only a partisan matter, but a vital theological decision. Southerners searched their Bibles and listened to sermons for signs of holy approval. The matter of secession had to be laid before their Maker. Turner reported that southern families gathered around their family altar to beseech God for the remedy. The response was loud and clear "Secede! Secede!"190 Whether or not southerners heard God's voice or felt God in their hearts and souls, the result was the same. Events, Turner argued, had a ripple effect creating a chain-reaction that accomplished God's greater purpose: “All are but parts of one stupendous whole, whose body nature is, and God the soul."191

With the formation of the Confederate States, Confederate patriotism was tied to southern piety. To support a southern civil religion, Turner encouraged the Confederacy to adopt national symbols that reinforced the notion of God's chosen people and their divine destiny of nationhood. The new national symbols, he argued, must be representative of their Christian faith and national allegiance. The Countryman addressed two of the Confederacy's national symbols. First, the Confederate flag was initially designed to place the stars of the Confederate states in the shape of a cross. Turner loved the idea of the imagery being both faith-based and nation-based - a true representation of a Christian South: "The southern people are yet found at the foot of the cross, and they cannot do better than adopt the cross as their nation's emblem, as it is the emblem of their

\footnotetext{
${ }^{190}$ Joseph Addison Turner, "My Impressions of Tom Cobb," The Countryman (Jan 12, 1863): 18.

191 Joseph Addison Turner, “Consoling Thoughts," The Countryman (Dec 13, 1864): 687.
} 
faith."192 Unfortunately, for Turner, the Confederate flag never took on the religious symbolism he so hoped for.

However, religion did influence the Confederate Seal, which depicted a picture of George Washington on his horse in the center with the words, "The Confederate States of America, 22 February, 1862, Deo Vindice," framing the circular seal. Upon its release, southerners translated 'Deo Vindice' to mean revenge of the spirit. Turner rejected this interpretation as he argued that the Confederate Seal represented God and nation. Their God was not vengeful or vindictive; instead, He represented "our guardian, our protector, our justifier, our deliverer, our vindicator, and our avenger (but never our revenger.)"193 Turner believed that negative, un-Christian interpretations damaged the southern cause by making it malicious in nature. Turner's interpretation reinforced his religious views by maintaining a moral code of virtue versus malevolence. In this way, he upheld the belief that God selected the southern people as the most righteous and deserving of an independent southern republic.

\footnotetext{
192 Joseph Addison Turner, “Our New Flag,” The Countryman (Mar 4, 1862): 2.

193 Joseph Addison Turner, "The Confederate Seal," The Countryman (May 19, 1863): 33.
} 


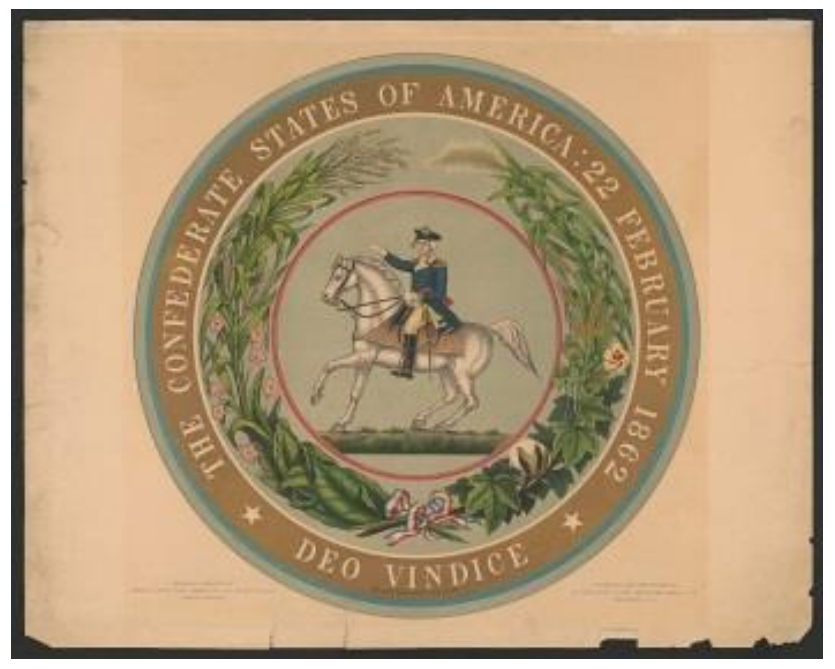

Figure 2. The Confederate Seal. (Source: Library of Congress Prints and Photographs Division, Washington, D.C.)

\section{Sinning and Appeasement}

Most Christians, North and South, took a providential outlook on the war. They believed that God kept score by judging northerners and southerners' morality and virtuousness. God rewarded their prayer, humiliation, and virtue and punished those who fell from grace, sinned, or lost their faith. ${ }^{194}$ Turner used this divine idea as the foundation for his civil religion, but elaborated on God's role. War was conducted "under the immediate eye, and supervision of the Almighty" and every action was a "link in the chain that binds God's purpose to its fulfillment."195 It was under God's direction that the southern people must repent their sins in order to remain in His grace. God demanded great moral and social change in order to secure southern independence. ${ }^{196}$ Turner also believed "that Almighty God, for good and wise purposes, is suffering this war to be

\footnotetext{
${ }^{194}$ George C. Rable, God's Almost Chosen People: A Religious History of the American Civil War (Chapel Hill: University of North Carolina Press, 2010), 2-3.

195 Joseph Addison Turner, "Fasting and Prayer," The Countryman (Mar 24, 1863): 99.

${ }^{196}$ Drew Gilpin Faust, The Creation of Confederate Nationalism: Ideology and Identity in the Civil War South (Baton Rouge: Louisiana State University Press, 1988), 41.
} 
waged. But we don't know what these purposes are. If it is intended as a punishment for our sins, why does the punishment all fall upon the innocent, while the guilty escape? Why does it all fall upon Southern people, and not yankees?"197 Turner refused to believe that the war was strictly a chastisement for southern sins and not the sinful North. If southerners were greater sinners than the northerners, Turner argued that the South should quit the war and surrender. ${ }^{198}$

Turner focused on the ways in which southerners appeared more deserving of God's blessing by alluding to their superior virtue. Most commonly, Turner contrasted southern virtue against the lack of virtue in the North; northerners were greedy, market driven, selfish, materialistic, corrupt, and unfaithful to name a few. Against these sins, the southern people elevated their culture and named themselves God's chosen people. However, slavery and greed were two sins that plagued the South. Southerners had to devise a way in which their sins were minimized and their virtue preserved in order to maintain the idea that they were God's chosen people. To justify their virtue, southerners used the Bible to sanction slave labor and depicted slaveholders as benevolent Christian masters. Additionally, slaveholders pushed the negative aspects of slavery onto either the slave traders, who tore apart families in order to make profits, or the abolitionists who stirred insurrections, rebellion, and bad behavior amongst the slaves. Slaveholders also claimed the benevolence of the institution because they supposedly Christianized their slaves, provided their daily necessities, and cared for them in sickness and old age. The potential sin of holding slaves was thus turned into a Christian act of brotherly love and charity. Additionally, just as Turner had denounced religious sects, he also condemned

\footnotetext{
${ }^{197}$ Joseph Addison Turner, "This War a Punishment," The Countryman (Jun 9, 1863): 45.

${ }^{198}$ Joseph Addison Turner, “This War a Punishment,” The Countryman (Jun 9, 1863): 45.
} 
Utah, Mormonism, and polygamy. Turner argued that the federal government recognized polygamy as Utah's "peculiar institution," but refused to look past slavery as the South's. He despised the fact that a territorial government was run by religious leaders in violation of the separation of church and state. Turner called it "a theocracy that jeopardized the homogenous makeup of the United States."

Greed was a far more serious offense that was not as easily explained away. Southerners prided themselves on being different from northerners, who were seen as greedy, money hungry capitalists. Slavery, however, was a capitalistic, market driven institution allowing slaveholders to profit from the labor of their slaves. Slaveholders continued to deny this by claiming the institution's benevolence. Additionally, greed became a harsh reality during the war. Due to the lack of subsistence crops to feed the Confederate army and home front, and the commodity shortages, many southerners profited from their neighbors and the nation. In order to divert the sin away from the southern Christian population, many blamed immigrants and non-Christians, including Jews. As white Christian southerners redirected the transgression away from themselves, they believed that God would continue to guide the South towards their independent Christian republic. ${ }^{200}$ In these ways, southerners tried to guard against any lapse in virtue.

Southerners perceived themselves as virtuous, but in reality southerners sinned just like northerners. From vanity, drunkenness, swearing, and dancing, to stealing, bribery and extravagance, southerners sinned daily. Turner was openly outraged at the sins committed by his fellow southerners. He denounced dances and parties as

\footnotetext{
${ }^{199}$ Joseph Addison Turner, "Utah and Polygamy," The Countryman (Jan 31, 1865): 64.

${ }^{200}$ Drew Gilpin Faust, The Creation of Confederate Nationalism: Ideology and Identity in the Civil War South (Baton Rouge: Louisiana State University Press, 1988), 49.
} 
thoughtless, irreligious, and immoral acts. Southerners should stop their frivolous frolicking; instead, he urged their attentions turn to the nation and its people. ${ }^{201}$ Reminding his readers of the sinfulness of stealing, he told the tale of a man who habitually stole ears of corn from a neighbor's field. One day the man took his son with him to hold the bag. As he looked to see if anyone was watching, his son reminded him he forgot to look up towards heaven. ${ }^{202}$ Addressing the temperance of southerners, Turner reprinted a Hillsdale Gazette article that denounced any southern man who had money to smoke and drink, but not provide for the good of southern society. In this case, the cause was the establishment of a library. Smoking and drinking, according to Turner, provided nothing in return while a public institution would benefit all. ${ }^{203}$

Turner also spoke out against infidelity and promiscuous behavior. When Confederate General Earl Van Dorn was mortally shot by a lover's jilted husband, Turner failed to mourn for the sinner. Instead, he attributed Van Dorn's death to his philandering actions as proof of God's heavy hand in war and the losses in the western theatre. In this way, Turner contrasted the battlefield losses in the West due to the sinfulness of Confederate generals to the successes in the East where the South had employed virtuous and Christian generals like Robert E. Lee and Thomas "Stonewall” Jackson. He further chastised other southern papers that praised Van Dorn's great deeds in battle by arguing that the South needed only Christian leaders who “act upon what is due to Heaven's just law.",204

\footnotetext{
${ }^{201}$ Joseph Addison Turner, "Balls, Parties \& Dances," The Countryman (Apr 25, 1865): 256.

202 Joseph Addison Turner, "God Sees Me," The Countryman (Jun 20, 1865): 303.

203 Joseph Addison Turner, "A First-Rate Library," The Countryman (Apr 24, 1866): 98.

${ }^{204}$ Joseph Addison Turner, "Van Dorn and his officers," The Countryman (Jun 2, 1863): 42.
} 
Turner also defended those who were mistakenly perceived as sinners. General "Stonewall" Jackson was known to take naps throughout the day even while riding his horse. A passerby, without recognizing the rider as Jackson, questioned where the man obtained liquor. The story goes that Jackson immediately awoke remarking that he better remain awake. ${ }^{205}$ Turner, who viewed Jackson as a pious and patriotic southerner, who spoke against the notion that Jackson would commit such as a sinful offense.

Turner's articles illustrated how both individual and collective sins were seen through God's eyes. Southerners had to combat against their own sinful nature by adopting atonement rituals. Although Turner condemned denominational atonement rituals, he openly supported established repentance ceremonies, which in turn supported his own brand of southern civil religion. He believed repentance was to be experienced in the same way by all southerners regardless of denomination, church membership, or religious position. Writing under the alias of Uncle Jimmy, Turner reminded his readers that while God loved all he also chastened and rebuked all. Therefore, repentance was required by all. ${ }^{206}$

Fasting, prayer, and humiliation days emerged as a nationalistic tool whereby southerners, through their public penitence, enacted Christian virtuous and righteousness. Turner considered fasting days a moral obligation for all white Christian southerners, both sinners and saints. Fasting days provided southerners a time to morally reflect upon

\footnotetext{
${ }^{205}$ Joseph Addison Turner, "Not Drunk," The Countryman (Sep 29, 1862): 5.

${ }^{206}$ Joseph Addison Turner, "Uncle Jimmy's Sermon on Repentance," The Countryman (Aug 16, 1862): 1 .
} 
themselves and their nation. ${ }^{207}$ He viewed the importance of fasting days as, "invoke[ing] Heaven's blessing upon our cause and to pray for the success of our arms."208

\section{Death and Suffering as God's Will}

Turner's civil religion also focused on discerning God's purpose in the face of southerners' brutal sacrifice and suffering borne for the Confederate nation. He wrote articles about the necessity of death in war and about how a southern soldier's death should be seen in the broader vision of southern independence. Turner also wrote about the deprivations on the home front, especially as experienced by southern women, and encouraged charity amongst his fellow Confederates. These themes were central to Turner's idea of devotion to the Confederate cause through a shared sense of sorrow, grief, and anguish.

The Civil War changed the rituals and meaning surrounding death. Nineteenth century Americans followed the Christian practices of a Good Death that was centered within the bosom of the family and was focused on the notion that the family member was conscious of his or her dying. Common Christian belief expected the dying family member to live in the afterlife with the full expectation that they would be reunited with other kin. Yet, many of these elements of a Good Death were impossible to realize when soldiers laid dying on the battlefields or in the military hospitals. Men who had never been more than twenty miles from their homes died in the wheat fields and peach orchards on battlegrounds hundreds of miles away. Death became a lonely experience. As Drew Gilpin Faust argues, coming to terms with this new experience of death meant

${ }^{207}$ Drew Gilpin Faust, The Creation of Confederate Nationalism: Ideology and Identity in the Civil War South (Baton Rouge: Louisiana State University Press, 1988), 26-29.

${ }^{208}$ Joseph Addison Turner, "Fasting and Prayer," The Countryman (Mar 24, 1863): 99. 
reinterpreting the Bad Death that occurred away from home and without one's family into a Good Death that justified the war and all its carnage. ${ }^{209}$

In this way, southerners, including Turner, reconstructed death on the battlefield into a Good Death that was patriotic, religious, and redemptive. The Countryman depicted battlefield losses of both famous Confederate generals and lesser known Confederate soldiers in order to illustrate that wartime deaths served a higher purpose. Following suit with most southern newspapers, The Countryman devoted poems, dirges, articles, and first-hand accounts of great battlefield deaths and expressed the loss felt throughout the South.

By far, Confederate General Thomas “Stonewall” Jackson was the most mourned fallen Confederate hero of the war. His death shook the Confederacy to its core and made him a martyr for the southern cause. Importantly, his death reinforced Confederate nationalism by bonding individuals together around the death of an important figure in the Confederate struggle. In other words, the joining of citizens in mourning fostered a collective national spirit. ${ }^{210}$ Moreover, as Jackson was considered a pious man who adhered to strict religious practices, he appeared to devout southerners as a messenger from God sent for a specific holy purpose. This played heavily on the notion that God was the war's orchestrator. God not only struck down southern sinners, but He also took southern saints to fulfill his great plan.

Many viewed Jackson's death as a spiritual crisis in which God removed those men on earth who could be viewed as the Confederate savior in order for the war to be a

\footnotetext{
${ }^{209}$ Drew Gilpin Faust, This Republic of Suffering: Death and the American Civil War (New York: Vintage Books, 2008), 6-7.

${ }^{210}$ Paul Quigley, Shifting Grounds: Nationalism and the American South 1848-1865 (Oxford: University Press, 2012), 200-201.
} 
divine victory. Jackson became an obstacle since southerners viewed Jackson's victories as a measure of his greatness, thus not giving due to God's hand in the military successes. Others believed that Jackson's death was due to the South's sins; thereby the loss of Jackson became redemptive for their cause. As an example, Reverend John Paris spoke of God's grace for lending the South such "a model of a Christian soldier!" but reminded his congregation to see the righteousness of God's providence to take Jackson from them. ${ }^{211}$

Turner spoke in similar ways about Jackson's death, imagining Jackson as both a lion and an eagle. Both animals were considered strong, majestic, and proud. His 1863 poem, "A Dirge to Jackson," acknowledged that his death was the heaviest blow to the southern cause. Turner's verse claimed the southern people must accept God's "chastening rod" ${ }^{212}$ in order for God to remain their sponsor. Like Reverend Paris, Turner's poem reflected the importance of repentance and redemption by the southern people and the critical role that God played in orchestrating the war. ${ }^{213}$

The Countryman likewise paid homage to the sacrifice of the ordinary southern soldier who also stood as a martyr for the southern cause. In 1862, Turner republished a popular death song during the Civil War, "All Quiet Along the Potomac Tonight," which described a bleak portrayal of war by recounting the death of a picket from a random bullet. This scene did not represent a bloody battlefield with thousands of dying soldiers, but one lonely soldier doing his duty in the dead of night. The song also imagined his

\footnotetext{
${ }^{211}$ Mark A. Noll, The Civil War as a Theological Crisis (Chapel Hill: University of North Carolina Press, 2006), 84-86; Daniel W. Stowell, Rebuilding Zion: The Religious Reconstruction of the South, 18631877 (Oxford: University Press, 1998), 4-6.

${ }^{212}$ Joseph Addison Turner, “A Dirge for Jackson,” The Countryman (May 19, 1863): 35.

${ }^{213}$ David B. Chesebrough, God Ordained This War: Sermons on the Sectional Crisis, 1830-1865 (Columbia: University of South Carolina Press, 1991), 273-274.
} 
death as a Good Death, with the family at the center of the scene, by having the soldier fondly remember his wife and children at home in his last moments. His death, according to Turner, was no less significant than that of those who died in battle charging the enemy. Every death in the war regardless of the circumstances was considered an act of God. $^{214}$

Sacrifices did not occur strictly on the battlefield, however; the southern people on the home front experienced sacrifice and suffering as well. Southerners believed that, as the orchestrator of the sectional conflict, God expected sacrifice not just from the men fighting for independence, but also from those who remained behind building the southern nation. While death in battle was seen as the ultimate sacrifice, suffering at home was defined around two main ideas. First was loss and mourning. The war not only changed how one died, but also how one mourned. The war turned death, which had been a private family matter, into a public business. Battles had been known to decimate large portions of entire regiments or inflict the highest death tolls seen at the time.

Communities in which individual regiments were mustered into service received news of the dead that did not impact one or two families, but dozens at the same time. The massive death tolls meant widespread and constant mourning, and families spent a significant amount of time burying and grieving for their loved ones. ${ }^{215}$ Southerners also sacrificed through shortages, rationings, and impoverishments. White southerners, especially women, faced the burden of being left home alone without their fathers, husbands, and sons to grow food, maintain crops, govern slaves, and run households. 4.

${ }^{214}$ Joseph Addison Turner, “All Quiet Along the Potomac Tonight,” The Countryman (Jul 12, 1862):

${ }^{215}$ Drew Gilpin Faust, This Republic of Suffering: Death and the American Civil War (New York: Vintage Books, 2008), 137-140. 
These sacrifices occurred, according to Turner, at a critical time when the faith of the southern people was most challenged. This was God's true test. While men struggled on the field of battle, the southern people at home were to remain vigilant. Turner urged them to "visit the sick, console the bereaved, minister to the wants of the destitute of the needy, and above all, to ever have the wants of the widow and orphans close to our bosom, and the promise will be ours." ${ }^{216}$ It was not enough just to pray and trust in the Lord. It was compulsory to administer Christian love and charity to the southern nation. Turner's articles were meant to inspire and encourage his readers to fulfill their moral obligations to the South. He hoped that people would read, ponder, and act upon such ideas. This was the essence of Turner's southern civil religion. God's good works administered by the southern people he believed would create a stronger Confederate nation.

The hardships on the home front, according to Turner, were blessed by the role that women played during the war. Turner praised southern women for their tireless efforts in encouraging men to muster themselves into service. Indeed, he considered Christian southern women - mothers, wives, sweethearts, and daughters - to be the backbone of the Confederacy. They nurtured the sick and wounded, knitted socks, shirts, and blankets for the soldiers, and created flags for regiments. Their Christian faith, allegiance to the Confederate cause, and their resourcefulness under extreme deprivations demonstrated their unwavering faith in God's divine plan.

Southerners, even in the final year of the war, understood the importance of their continued commitment to God's plan. Turner, in January 1865 , recounted to readers the

${ }^{216}$ Joseph Addison Turner, "Reflections on the Departing Year," The Countryman (Dec 8, 1862): 85. 
words of Henrietta Barnes, a soldier's wife, who wrote a letter to the editor of the Constitutionalist stating that she and her husband willingly submitted to suffer any inconvenience rather than submit to the enemy. Turner commented that southern men should be ashamed at any behavior that did not represent the same spirit as Mrs. Barnes. All southerners, Turner wrote, especially those who remained on the home front, must recognize individual sacrifice or the alternative, which was submission to the morally corrupt North. $^{217}$

While Turner viewed the charitable efforts of women as an essential and integral part of his southern civil religion, he also viewed charity by all southerners as a necessary sacrifice in securing southern independence. Throughout The Countryman, Turner challenged southerners to be more benevolent by providing for their armies and the southern population. It was, according to Turner, the collective duty of all Confederate citizens to work together in a sort of "imagined community" to provide for the nation as a whole. This idea was predicated on the Christian notion of charity, which reinforced the image of a southern Christian republic. As southerners joined together to care for one another, the love and patriotism of one's country intensified. It was not only their Christian duty; it was their Confederate duty. ${ }^{218}$

Turner defined true Christian charity by what charity was not. He denounced those southerners who only offered charity when it was publicly announced by subscription lists, newspaper acknowledgements, or public collections. He quoted Matthew 2:6 that giving did not require men to acknowledge their own good deeds. For Turner, it was the unknown giver who was charitable in the smallest amount that made

\footnotetext{
${ }^{217}$ Joseph Addison Turner, “A Letter from a Soldier's Wife,” The Countryman (Jan 17, 1865): 33.

${ }^{218}$ Joseph Addison Turner, “God Bless our southern Women!” The Countryman (Dec 1, 1862): 3.
} 
the biggest difference in people's lives. The women who knitted socks for the armies received no public credit; rather, "God makes our motive the measure of our merit.",219 Turner scolded church congregations when collections taken up privately resulted in a pitiful sum of a few dollars. The same collection taken with publicly announced contributions created a plate full of money. "What a transformation!" Turner chided. ${ }^{220}$

Turner also criticized religious congregations that focused solely on the distribution of religious newspapers and tracts rather than food and other necessities for the needy. Hungry men, women, and children, he wrote, did not want to listen to preaching or moral lecturing in their time of need. He believed that most religious congregations were out of touch. It became apparent that congregations never visited the poor and did not understand the southern people's immediate needs. Turner publicly condemned weekly prayer meetings as a "cheap way to serve one's country." ${ }^{221}$ In contrast, he related remarkable stories of white southern bravery, perseverance, and unwavering patriotic duty. One story told of a poor widow with three small children in North Carolina. Understanding the plight of the Confederate cause, the good Christian woman took her children each day into the field where she built a make-shift pen around her children while she planted and cared for her subsistence crops. The result of her efforts yielded the Confederacy three hundred sixty-seven bushels of corn. This abundant harvest fed her family and the remaining fed the southern home front. Turner applauded

\footnotetext{
${ }^{219}$ Joseph Addison Turner, "A Sermon on Alms/Giving," The Countryman (Apr 22, 1862): 2.

220 Joseph Addison Turner, "Pharisaism," The Countryman (Jun 10, 1862): 3.

${ }^{221}$ Joseph Addison Turner, "Bread vs. Tracts," The Countryman (Jun 16, 1863): 50.
} 
her efforts, writing that, "The brow of that woman is worth the proudest laurels that ever rewarded the virtue of the patriot, or testified to the endurance of the hero."222

\section{Virtue}

By advocating a collective moral superiority, Turner used his civil religion to diminish internal conflicts, remind southerners of their national duty, and to warn against those actions that challenge the South's virtuousness. These acts taken together would place the southern home front in alignment with the Confederacy's divine mission. Before the war, families were concerned with feeding the mouths within their households. The war expanded the southern family beyond the walls of their homes. It grew far and wide to encompass towns, counties, and states. Yet, the Confederacy had been plagued from the beginning with internal conflicts and petty disputes that Turner considered "things unworthy the champions of our great and holy cause." His articles in The Countryman promoted harmony and hoped that southerners would "postpone private griefs, to forget personal wrongs, quarrels, and ambition, til southern independence were established."223

Home front survival was a collaborative effort, which was not always fully embraced by all classes. Slaveholders, especially planters, had the most to lose with Confederate defeat, especially in their slave property and the institution itself. Planters found self-sacrifice particularly challenging as they were not accustomed to yielding to other's interests and refused to place their self-interests aside for the greater good of the Confederacy. They were against the impressment of property and slaves, avoided

\footnotetext{
${ }^{222}$ Joseph Addison Turner, “An Interesting Incident,” The Countryman (May 3, 1864): 249.

${ }^{223}$ William Wilburforce Turner, "United We Stand Divided We Fall," The Countryman (May 3, 1864): 242.
} 
conscription through the Twenty Negro Law, and refused to grow subsistence crops to support the Confederate army and home front. The middling classes, the yeomanry, and poorer white southern families felt the sacrifices of war more as their property and crops were impressed into military service, their men were drafted into the Confederate army, and they were barely able to feed themselves. Planters' actions created a level of hostility between classes that did not go unnoticed by Turner, who was a planter himself.

The Countryman, whose primary target audience was planters, provided Turner ample opportunity to remind the planter class of their obligations to the Confederacy, but also to shame and embarrass them into recognizing their selfishness. To advocate his southern national community, he reminded planters that "We live not for ourselves, but for country, and duty, for truth and God." 224 Turner clearly identified the class dynamics of the war. The planter class, believed Turner, was sinful. These sins had to be corrected into order for the Confederate national project to succeed.

He published a variety of poems and articles directed towards the planter class in an attempt to promote national virtue. His 1862 poem "A Cry for Bread" was written to planters from the perspective of the southern soldier. While he was off fighting, the soldier reminded the planters at home to feed his family. The poem situated responsibility squarely on the planter. The soldier went off to fight "your" battles and drive the enemy from "your" homes and protect "your" slaves and land as some planters refused to give up their cotton crop for subsistence food. The soldier criticized King Cotton as a monarch out to starve the land. Just as it was the duty of the soldier to fight the enemy on the battlefield, it was the planter's responsibility to fight starvation and poverty on the home

${ }^{224}$ Joseph Addison Turner, “Cheer Up,” The Countryman (Feb 7, 1865): 71. 
front. The planter who did not heed the moral of the story would alienate the soldier. He would have no choice, but to return home to provide for his family, leaving the planter, his land, and his slaves undefended. ${ }^{225}$ Turner also wrote articles appealing to planters' responsibility to not only grow enough provisions for their own family, but to produce as much as possible for the armies and the home front. He recommended that planters limit cotton production to one acre and plant subsistence crops in the remaining acres for the Confederate war effort. Turner chided, "Let it be remembered, that you owe it as a solemn duty to God and your country - to your wives and children - to religion and liberty, to raise very large crops of provisions."226 Again, Turner drew an association between Christian benevolence and Confederate devotion. When his calls were not heeded, Turner lambasted those farmers and planters for betraying God's mission: "The cry which will go up to heaven from starving men, women, and children, calling down the curses of Almighty God upon the authors of all their woes," he wrote in 1862 . The planters' transgressions would not only bring God's fury, but also the "avenging wrath of an outraged and indignant people."227

One of the most glaring transgressions of the Confederacy was extortion. The increased wartime demand for supplies caused shortages across the South resulting in escalating prices. For many southerners, devalued Confederate money made it impossible to buy necessary household supplies. Items that were once in abundance, like bread, salt, and coffee, became rare pleasures. As a result, avarice and extortion became

\footnotetext{
${ }^{225}$ David M. Potter, “The Historian's Use of Nationalism and Vice Versa," The American Historical Review, Vol. 67, No. 4 (July 1962), 926, 936; Joseph Addison Turner, “A Cry for Bread," The Countryman (Apr 15, 1862): 1.

${ }^{226}$ Joseph Addison Turner, "Important to Everybody," The Countryman (Mar 11, 1862): 4.

227 Joseph Addison Turner, “A Glory Picture,” The Countryman (Mar 4, 1862): 1.
} 
commonplace in the South, challenging southerners' sense of moral virtue and, for sure, standing as evidence of southern selfishness. ${ }^{228}$

Before the war southerners perceived themselves as being anti-capitalist, even though slavery was in reality entirely immersed in market capitalism. This perception was necessary for southerners to distance themselves from what they viewed as the corrupt, market-driven capitalism of the North. The war, however, created a reliance on the markets that allowed greedy southerners to profit off their fellow countryman. Extortion threatened the southern notion of Christian virtue because their virtue rested on the misguided idea that they were separate from the dirty commercialism and profitmindedness of the North. Extortion was thus considered a cardinal sin that threatened southerners' sense of their own righteousness. The actions of the extortionists, such as raising prices on much needed commodities, withholding items from the market until the need for those items drove prices higher, and not donating or selling needed goods at reasonable prices to soldiers' families, caused great anxiety across the South. As a result, the Confederate government, as well as state governments, grappled with laws to restrict speculation. In an attempt to shame extortionists, southerners played the blame game on a variety of occupations, including planters, mechanics, merchants, and manufacturers.

Turner recognized extortion as a great crime against the Confederate cause. Speculation and extortion called into question Turner's civil religion by exposing the sinfulness of white Christian southerners. In The Countryman Turner denounced not only the immoral act of extortion, but also the accusations and finger-pointing of southerners who waged an internal battle against those labeled extortionists. This level of dissension

\footnotetext{
${ }^{228}$ Drew Gilpin Faust, The Creation of Confederate Nationalism: Ideology and Identity in the Civil War South (Baton Rouge: Louisiana University Press, 1988), 44-45.
} 
from within the Confederacy created a rift in the South's nationalistic goals. In an 1863 article, he asked each southerner to assess their own moral consciousness. It seemed as though everyone was trying to convince everyone else that they were good southern men, but it was always done under shrouds of doubt and criticism. Instead, Turner encouraged each man to "look carefully at his motives, and then answer to his inmost hearts if he has not frequently deceived himself, and imagined that his abuse of others sprang from patriotism" when they did not. ${ }^{229} \mathrm{He}$ believed that everyone had a right to make money. However, one person profiting led others to condemn them as extortionists. Turner argued that making a living as a good Christian was not the same as being a sinful extortionist and making money out of the misfortunes of others was a sin that hurt the southern cause as much as battlefield losses. There was no greater travesty to the Confederate cause than un-Christian southern behavior. ${ }^{230}$

\section{Post-War}

During the war, Turner's religious writings in The Countryman condemned denominational variances, encouraged southern morality, condemned southern transgressions, and acknowledged God's purpose in the South's grief and misery. In order to shape a new Christian republic, The Countryman had educated, criticized, influenced, and supported the Confederate nation through its devotion to God's divine plan for the South.

After the war, Turner's religious views seem contradictory on the surface, but were self-serving for the purpose of reconciling the two sections, North and South, with little punishment to southerners for the past four years of war. Turner wrote that

\footnotetext{
${ }^{229}$ Joseph Addison Turner, "Some of the Effects of the War," The Countryman (Sep 1, 1863): 70.

${ }^{230}$ Joseph Addison Turner, "High Prices - Farmers," The Countryman (Oct 27, 1863): 4-5.
} 
northerners should extend brotherly love and charity to the southern people.

Christianity's moral code should dictate the reconstruction of the union. In a sermon given in July 1865, Turner defined God's mission: "It was not war, not bloodshed, not the sword." Instead, it was peace, which he argued was the very origin of Christianity. The Lord had stopped the war; therefore, He wanted peace, love, and charity.

Turner also recognized southern defeat at the hand of God, not the North. ${ }^{231} \mathrm{He}$ had accepted that the Confederacy "had failed to reach the port we desired, but God has brought us to the one for which he steered the bark in spite of ourselves. We accept surrender of our armies as an act of God, and will endeavor to bow submissively to his will." ${ }^{232}$ From this perspective, Turner believed that God's decision to end the war was not because of the sinfulness of the South, but because God's plan for the South had changed. He had greater things in store for southerners. Turner's interpretation was probably like most southerners at the time. He viewed Confederate defeat by the hand of God clearly more palpable than defeat by the Yankees.

Turner's efforts forging a public religion around a devout and secular Confederate nation quickly fell apart after the war's end. While he along with many southerners continued to cling to the belief that they remained God's chosen people, the common symbols and beliefs that held the nation together were gone. The Confederate Seal held no special place in the hearts of southerners any longer. Fasting and prayer days focused on the reconciliation of the entire Union. Charitable acts supporting the southern poor and needy gave way to obtaining much needed supplies from the North, the use of greenback

\footnotetext{
${ }^{231}$ Joseph Addison Turner, "Peace, The Origin, and the End of Christianity: A Sermon," The Countryman (Mar 13, 1866): 52-55.

${ }^{232}$ Joseph Addison Turner, “Our Course,” The Countryman (May 23, 1865): 286.
} 
currency, the reality that southern slaveholders were without their labor force, and a Union military presence that controlled the South. Southerners, including Turner, must have been praying for God's intervention in the aftermath of defeat. Perhaps, they hoped the Confederacy would find a way to endure a little longer in order to grasp onto their once commonly set of beliefs that had originally bound southerners together in their quest for a new Christian republic. 


\section{CHAPTER IV}

\section{SLAVERY}

Slavery was at the heart of the southern agrarian economy, contributed to the prosperity of the northern economy, and made the United States an economic world power. In the North, insurance brokers, bankers, and industrialists reaped the profits from the global cotton market. In the South, slavery and King Cotton were profitable for slaveholders who owned the land and slaves, and the slave traders who bought and sold their labor. ${ }^{233}$ In 1793 with the invention of Eli Whitney's cotton gin, the South's cotton production exploded. By 1810 it produced 177, 824 bales of cotton and by 1860 the South had its greatest cotton crop ever producing $7,000,000 .{ }^{234}$ Southern slaveholders and slave traders alike benefited from the cotton boom as it caused a huge increase in the domestic slave trade due to the fact that cotton was a labor intensive crop that required much manpower.

Slavery was not only central to the southern economy, but also its identity, as it forged a bond that transcended any other shared affiliation or loyalty among white southerners. Culturally, slavery established southerners' way of thinking and behaving

${ }^{233}$ Edward Baptist, The Half Has Never Been Told: Slavery and the Making of American Capitalism (New York: Perseus Books, 2014), 25.

${ }^{234}$ James McPherson, Battle Cry of Freedom: The Civil War Era (Oxford: Oxford University Press, 1988), 39, 86, 91, 100-102. The production of cotton in the South varies dramatically depending on the source. 
by creating a shared set of attitudes, values, goals, and practices that characterized the southern way of life. To Turner, as a southern slaveholder, slavery was undoubtedly important economically; but as a cultural nationalist, he viewed slavery as crucial to the existence of the Confederacy. As he wrote in The Countryman in 1862, "I say, negro slavery is the South, and the South is negro slavery.",235

This chapter demonstrates the ways in which Turner used The Countryman to defend slavery, not only as a political tool and economic institution, but more importantly, as a cultural institution. Turner, as did many southerners, believed slavery was the bedrock of their culture that they were fighting to preserve. Although Turner was fiercely pro-slavery and, in his public writings, used pro-slavery arguments to help unify the Confederate nation, his views on slavery were fraught with complexities and contradictions, especially as the war waged on, and slaves were emancipated. Indeed, Turner's defenses of slavery and his responses to emancipation illustrate the trials and tribulations experienced by white southerners as slavery, the foundation of their society, disintegrated.

\section{Defending Slavery}

Southern cultural nationalists, like Turner, used print culture to convey the benefits of slavery, to stultify the abolitionist world, and to promote the slaveholding as an attainable goal. By highlighting the paternalistic relationship between master and slave, Turner advertised slavery as a morally just system that was mutually beneficial for all of southern society. ${ }^{236}$ Writing in his 1860 pre-war quarterly journal, The Plantation,

\footnotetext{
${ }^{235}$ Joseph Addison Turner, "The Old Plantation: A Poem," The Countryman (Oct 27, 1862): 36-37.

${ }^{236}$ Drew Gilpin Faust, The Creation of Confederate Nationalism: Ideology and Identity in the Civil War South (Baton Rouge: Louisiana State University Press, 1988), 59-60; Michael T. Bernath, Confederate
} 
Turner suggested that slavery was not solely for the benefit of masters, but also for the benefit of slaves. A slave, Turner suggested, had the right to be cared for by his master, to cease work on the Sabbath, and to have only reasonable work assigned to him. While the slaveholder might reap the economic benefits from slave labor, in Turner's mind, the slaves received privileges that "are necessary to their enjoyment and happiness."237

In The Countryman, Turner at times similarly employed the language and tropes of paternalism in order to make a point or solidify an argument that would align more with his readers. ${ }^{238}$ He criticized slaveholders who did not feed their slaves as cruel because "we must feed the negro, for him to make more food for the soldier. They are needed to sustain the population., ${ }^{239}$ In another example, Turner published a lesson for the southern youth and future slaveholders by demonstrating how to be a "good little master, and a good big master, to feed [slaves], and clothe [slaves], and take care of [slaves.] It is best for all negroes to have good masters." 240 The message implied that slaves required caring masters because unhappy slaves caused larger problems for white southern society such as insurrection, civil disobedience, and stirring southern fears.

Paternalism was the leading defense of slavery in the antebellum period. It reflected the attitudes of white southerners who acted as caregivers for African Americans without providing them any choice in their status as slaves. The foundation of paternalism was a master-slave relationship based on, what white southerners claimed

Minds: The Struggle for Intellectual Independence in the Civil War South (Chapel Hill: University of North Carolina Press, 2010), 29.

${ }^{237}$ Joseph Addison Turner, The Plantation (Mar 1860): 3-4, 48-51, 102-103; (Jun 1860): 324-329.

${ }^{238}$ Joseph Addison Turner, "Our Negroes," The Countryman (Mar 15, 1864): 136-137; Joseph

Addison Turner, "Ranaway from the Yankees," The Countryman (Mar 8, 1864): 120; Joseph Addison Turner, "Facts on Slavery," The Countryman (Mar 1, 1864): 106.

${ }^{239}$ Joseph Addison Turner, "Soldiers Families," The Countryman (Mar 24, 1863): 98.

${ }^{240}$ Joseph Addison Turner, "Cutting Wheat," The Countryman (Nov 24, 1862): 69. 
was, a mutually beneficial relationship. While slave owners believed that they treated their slaves in a fair and decent manner, the slaves themselves did not view their treatment in the same light. Slaveholders believed, according to Eugene Genovese, that slavery was a reciprocal relationship in which a slave's labor was exchanged for food, care, and protection. Slaveholders rationalized the justness of the institution by legitimizing the give-and-take of their relationship. The reality of paternalism was, in fact, the stark opposite. Fraught with resentment and hatred, the complex relationship between masters and slaves grew out of a necessity for southern whites to control and discipline enslaved blacks and to keep them in a subordinated position. ${ }^{241}$

Slaveholders saw themselves not as profit-minded entrepreneurs, but as feudal lords who stood above the greed and materialism of the market. Paternalism grew out of this mindset. Unlike northern industrialists, they cared for and protected their labors.

The reality of slavery, however, had nothing to do with the benevolence of masters. In Soul by Soul, Walter Johnson argues that the slave trade shows how shallow paternalistic claims actually were. Slaveholders portrayed themselves as nurturing caretakers that were uninfluenced by the slave trade, the cotton boom, the markets, and turning a profit at the expense of their extended black families, but reality reveals another picture. In order to rationalize these transactions and uphold an image of themselves as benevolent masters, they depicted the buying and selling of slaves, however, as mere

\footnotetext{
${ }^{241}$ Eugene Genovese, Roll Jordan Roll: The World The Slaves Made (New York: Vintage Books, 1976), 20-25.
} 
accidents, opportunities, or necessities brought on by a death in the family or an unforeseen debt. ${ }^{242}$

Johnson demonstrates that slavery was fully immersed and dependent upon capitalistic markets. Slaves were commodities used as collateral on mortgages and loans. They were bought and sold based on economic necessity, as well as market conditions that reaped the largest payout for the slaveholder. Johnson shows that slaveholders caring for their slaves was not, in fact, a paternalistic act, rather it was a mechanism by which slaveholders maximized their profits from their commodities by ensuring their slaves were healthy to work the long hours in the fields. Yet to uphold their sense of their own paternalism, slaveholders projected the ugliness of the institution onto the slave trader, who was central in the economic transaction. The slave trader, rather than the slaveholder, was painted as the monster who broke apart slave families. This relinquished the slaveholder of any responsibility from the transaction and any level of guilt they may have felt. $^{243}$

James Oakes, like Johnson, argues that slaveholders were, above all, capitalist entrepreneurs who were completely immersed in the marketplace. The dictates of capitalism and paternalism were entirely at odds. Oakes points out that most slaveholders owned very few slaves and it was that majority of smaller slave owners who pursued economic growth by purchasing more slaves and land. With no sense of paternalism, these slaveholders built their master-slave relationship based on the economic conditions

\footnotetext{
${ }^{242}$ Walter Johnson, Soul by Soul: Life Inside the Antebellum Slave Market (Cambridge: Harvard University Press, 1999), 21-29, 163-180.

${ }^{243}$ Walter Johnson, Soul by Soul: Life Inside the Antebellum Slave Market (Cambridge: Harvard University Press, 1999), 21-29, 163-180.
} 
of the markets. ${ }^{244}$ Paternalism crumbled under the pressure of slaveholders' use of the markets in order to maximum their profits and purchase more land and slaves.

Conversely, Genovese argues that slaveholders did not see themselves as capitalists. Paternalism rather than the markets shaped the master-slave relationship and it was truly. Because slaveholders and slaves lived in close proximity to one another, their daily interactions created a mutual bond of affection while simultaneously harboring distrust and hatred. Slaveholders had to believe that their paternalistic relationship was one based on a moral obligation and duty to one another; otherwise their entire justification for slavery would disappear leaving them unable to defend their institution. ${ }^{245}$

The market-driven slaveholder, who viewed slaves simply as a means to profit, was the kind of master that Turner sometimes presented himself. Some of his journal entries reveal that he viewed slavery strictly in terms of economic and social necessity. Although he did see himself as responsible for the care of his slaves, very few entries referenced their well-being. Slaves, in his view, were commodities purchased and sold for their labor. Turner's views on the benevolence of the institution are seen more in The Countryman than in his personal journal.

Turner was a third generation slaveholder. His paternal grandfather, also named Joseph Turner, settled his family in Georgia in 1793, and by 1795 owned four hundred and six acres and thirteen slaves. In 1811, Turner's grandfather purchased the plantation nine miles from Eatonton, Georgia, where Turner was born and The Countryman was

\footnotetext{
${ }^{244}$ James Oakes, The Ruling Race: A History of American Slaveholders (New York: W.W. Norton \& Company, 1982), 217-218.

${ }^{245}$ Eugene Genovese, Roll Jordan Roll: The World The Slaves Made (New York: Vintage Books, 1976), 20-25.
} 
later published. ${ }^{246}$ This heritage assured him more financial security than nonslaveholders trying to obtain their first slave or slaveholders with a few slaves. For many small or non-slaveholders looking to expand their labor force, the purchase of a slave came at an enormous cost. Turner, on the other hand, was given slaves upon leaving his father's house. His financial situation allowed him to immediately surpass other white southerners without much financial sacrifice or years of scrimping and saving. ${ }^{247}$ Interestingly, in writing his childhood reminiscences in his personal journal, Turner depicted his family nostalgically as kind, paternalistic caretakers. Turner's personal journal and The Countryman were his two main written sources that complemented and contradicted one another. While The Countryman revealed Turner's reactions to the events and circumstances of the war as they occurred, his personal journal, on the other hand, was written some twenty years later in hindsight. One's recollections from the past, not only challenge one's ability to recall an event as it occurred, but also allowed for embellishment. Turner's memories of slavery in his youth differed greatly from his ideas about slavery once he became a slave owner in adulthood. He recollected his childhood as one of building relationships with the family slaves that suggested a mutual bond of affection. These nostalgic reminiscences, in which he saw his family as good caretakers, implicitly supported the paternalistic defense of slavery. For example, during one harvest of a potato field, Turner roasted a batch with the help of a "dozen lazy negro children." His description of the "lazy" slave children implied that his family allowed slaves' leisure time and did not work them very hard in the fields. Turner

\footnotetext{
${ }^{246}$ Lawrence Huff, "Joseph Addison Turner: A Study in the Culture of Ante-Bellum Middle Georgia" ( $\mathrm{PhD}$ diss., Vanderbilt University, 1958), 8-15.

${ }^{247}$ James Oakes, The Ruling Race: A History of American Slaveholders (New York: W.W. Norton \& Company, 1998), 52-57.
} 
also viewed his childhood as one that was filled with slave friendships: he remembered Kitt, a slave boy who belonged to his father, who gave him a trap to catch partridges. $\mathrm{Cu}$, another slave, told him haunted tales about the plantation; and, one of the family's older slaves, Isaac, loved to talk and laugh with Turner. When confined to the house with thigh bone disease, Turner played outdoors while one of the slaves pulled him around the garden in the wagon. When he was able to use crutches to get around on the plantation, Turner met a crippled slave boy named Tom also on crutches. They spent his days fishing and hunting together. ${ }^{248}$ All of these stories further substantiated the paternalistic notion that Turner's family slaves were well provided for and allowed ample time for recreation.

Turner continued with his reminiscences in his personal journal by defending slavery and his relationship with his slaves when he wrote: "There are the negroes too with whom I have spent many a glad day hooking the minnow and chasing the hen. Let the fanatic at the North say that we treat our slaves as brutes. They know nothing of the feelings which pervade the negro's bosom for the white child with whom he has been reared and with whom he has so much associated. They know nothing of the kindly glow of mutual sympathy and sorrow between the son and the slave when the latter leaves the paternal roof. ${ }^{, 49}$ As with most slaveholding families, Turner believed his relationships with slaves entailed a mutually shared affection. He wrote from the perspective that he and his family, like many slave owners, cared for and nurtured their slaves; therefore, their slaves must have loved them in return. Without this belief, the paternalistic defense of slavery made no sense.

\footnotetext{
${ }^{248}$ Lawrence Huff, "Joseph Addison Turner: A Study in the Culture of Ante-Bellum Middle Georgia" (PhD diss., Vanderbilt University, 1958), 37-46.

${ }^{249}$ Autobiography of Joseph Addison Turner, Robert Woodruff Library Microforms. Emory University, Emory, Georgia, July 21, 1849, 77.
} 
Turner's transition to master, however, was not portrayed in his personal journal as a nostalgic recollection of his past; rather he referenced his slaves in economic terms. Turner's use of financial references when describing his slaves in his personal journal were not necessarily at odds with his paternalistic tone when describing his slaves in The Countryman. It was common for slaveholders to view their slaves as commodities, but also act as their caregivers. These ideas were not mutually exclusive. Evidence of his pecuniary pursuit as a master can be found wedged between two poems in his personal journal where Turner listed his chattel property with specific attention to age and value: Matt, 29 years old - $\$ 2,000 ;$ Kitt, 41 - $\$ 1,500$; and Tempe, 35 - \$1,000. In total, eleven slaves were listed. ${ }^{250}$ Turner viewed his slaves as valuable property listed individually, not grouped by family or in any particular order of fondness. A few pages later, under the title of "Items from My Pocket Book," Turner noted that on January 24, 1860, he was going to sell his slaves for the following prices: Matt - $\$ 1,600$, Kitt - $\$ 1,000$, Tempe $\$ 850$ along with the rest of them. In each case, he considered selling his slaves for less than their value noted a few months earlier. ${ }^{251}$ There was no indication why the prices were lower, as the next journal entry was a list of book titles. Turner started his journalistic venture, The Plantation, in 1860 and perhaps needed the funds to finance his quarterly journal. Based on his July 1865 journal entries, Turner maintained most of the slaves listed in 1859 with the exception of two names that disappeared from the list. By the end of the war, he owned a total of twenty-seven slaves plus eight hired hands who

${ }^{250}$ Autobiography of Joseph Addison Turner, Robert Woodruff Library Microforms. Emory University, Emory, Georgia, December 1859.

${ }^{251}$ Autobiography of Joseph Addison Turner, Robert Woodruff Library Microforms. Emory University, Emory, Georgia, December 1859. 
were slaves hired from neighboring slaveholders. ${ }^{252}$ The total of slaves owned by Turner further illustrated his rank among the few elite planters. In addition, he had the pecuniary ability to bring on additional slave labor as needed, which would have been out of reach for most slaveholders.

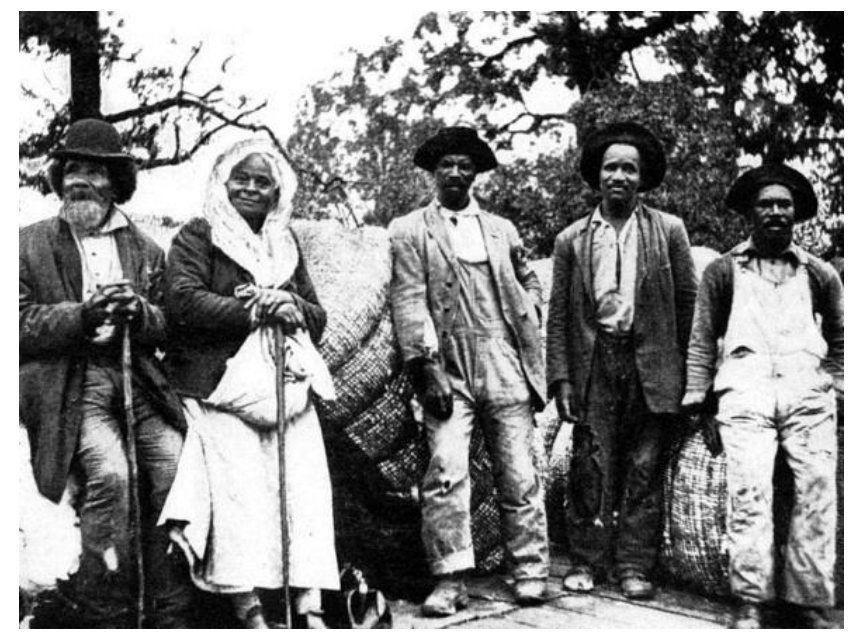

Figure 3. Five slaves from Joseph Addison Turner's Turnwold Plantation in Eatonton, Georgia. Several of Turnwold Plantation slaves became models for Uncle Remus, Aunt Tempy, and other figures in the African American animal tales immortalized by Joel Chandler Harris. (Source: Photography courtesy of New Georgia Encyclopedia, Manuscript, Archives, and Rare Book Library, Emory University.)

Although Turner tended not to say much about himself as a paternalist, with the exception of his childhood reminiscences, The Countryman did deploy paternalistic arguments to defend slavery. Since paternalism was so central to southern defenses of slavery and southern identity, his pro-slavery articles used paternalism to unite all Confederates, slaveholding and non-slaveholding, around the idea that slavery was central to Confederate virtue and honor. Turner reprinted an article from the Augusta

\footnotetext{
${ }^{252}$ Autobiography of Joseph Addison Turner, Robert Woodruff Library Microforms. Emory University, Emory, Georgia, July 9, 1865. In Michael Bernath's Confederate Minds: The Struggle for Intellectual Independence in the Civil War South, Bernath noted that Turner had over one hundred slaves. He cited “A Familiar Talk with My Readers" from The Countryman's January 12, 1864 issue. However after reviewing that article, I found no reference to the number of slaves Turner owned. I found a more accurate count of Turner's slaves in his personal journal.
} 
Constitutionalist in which a slave had escaped the Union lines to return to his master, a large Mississippi planter. According to the slave's account, the Union army had drilled him for six weeks without rest, separated him from his family, and shipped his wife and daughter to the North to fend for themselves. The paper called the master-slave reunion as "a most touching scene." The slave's experience would stand as evidence for Turner's readers that not only did the North provide a "false notion of freedom," but that southern slaveholders provided a higher level of care for a slave and his family within the institution of slavery than the North did outside of it. ${ }^{253}$ This type of paternalistic defense became prevalent in Turner's post-war writings as he argued that the best suitable position for blacks was in bondage.

On the other hand, other pieces in The Countryman eschewed such notions of benevolence. In one example, he advocated controlling slaves to ensure their submissive position in society. When slave patrols frightened and whipped slaves without just cause, Turner argued the role of patrols was to render slaves subordinate through words and actions. ${ }^{254}$ When one unruly slave questioned his position in life and threatened southern white society, as a "ward" of M. Dennis Esquire did in Early County, Georgia, Turner believed justice had been carried out when two white men shot and killed him. ${ }^{255}$

Turner similarly used The Countryman to defend slavery as a viable labor system and a suitable position for blacks. He viewed slaves as a lesser race that could handle harsher sacrifices, which was not incompatible with paternalism. The war only exacerbated that common sensibility. Due to the scarcity of meat, Turner urged

\footnotetext{
${ }^{253}$ Joseph Addison Turner, "A Faithful \& Sensible Servant,” The Countryman (Jan 12, 1864): 12.

${ }^{254}$ Joseph Addison Turner, "The Patrol Laws," The Countryman (Sep 22, 1863): 90.

${ }^{255}$ Joseph Addison Turner, "We learn that a very unruly negro man," The Countryman (Apr 7, 1863):
} 7. 
slaveholders to withhold meat from their slaves' diets; instead, he argued, their diets should be supplemented with vegetables from the plantation. ${ }^{256}$ "The question of subsistence for the army, is now a question of subjugation or freedom," he wrote. ${ }^{257}$

Turner not only made use of paternalistic defenses of slavery, but other defenses as well, including pseudo-scientific defenses that presented the differences between blacks and whites as biological and immutable. First seen in Thomas Jefferson's Notes from Virginia (1787), this approach justified white superiority and slavery by asserting that those of African descent were physiologically suited for slavery. ${ }^{258}$ Turner used a reprinted excerpt from Chambers Journal within The Countryman to illustrate the idea that people of African descent, specifically slaves, were like animals in that they ate ants, mice, and serpents, they did not marry or hold the institution of marriage as necessary, but procreated often, and were unable to properly groom themselves as white southerners did. Referring to them as "human monkey," Turner not only linked this account to their physiological inferiority, but also made a political statement when he wrote that the Africans "are the next degree about the yankees" meaning that Turner viewed northerners as the lowest of all humans. ${ }^{259}$

Even before The Countryman, Turner put forward the pseudo-scientific defense of slavery in his quarterly journal, The Plantation. He argued at great lengths that a black man was not simply a white man with black skin as, he wrote, there were many

\footnotetext{
256 Joseph Addison Turner, "Soldiers Families," The Countryman (Mar 24, 1863): 98.

257 Joseph Addison Turner, "Bacon," The Countryman (Nov 10, 1863): 4.

258 Thomas Jefferson, Notes on the State of Virginia, excerpt (1787), from Defending Slavery: Proslavery Thought in the Old South, ed. Paul Finkelman (Boston: Bedford/St. Martin's, 2003), 47-54.

${ }^{259}$ Joseph Addison Turner, “A Barbarous African Tribe,” The Countryman (Jul 19, 1862): 3.
} 
differences in "physical, moral, and mental conformation" between the races. ${ }^{260}$ This argument, known as polygenesis, rested on the belief that a race was incapable of modification or adaptation over time. Polygenesists also believed that Africans were so biologically distinct from whites that they constituted another species. Blacks as a race had been inferior hundreds of years ago and would remain inferior throughout time. Therefore, the social position of blacks as slaves could never change. ${ }^{261}$

This approach was not widely accepted by southerners as it was at odds with scripture, according to which all humans, of all races, descended from Adam. Most southern Christians thus viewed polygenesis as a direct attack on religion. ${ }^{262}$ Some scientists reconciled their belief in biological differences between the races with the Bible by arguing for monogenesis, or the idea that, although the races were of the same species, they were nevertheless physiologically distinct. ${ }^{263}$ In any case, the Bible was as important to the defense of slavery as was paternalism; indeed, they went hand in hand, since the Bible affirmed the humanity of slaves. ${ }^{264}$ By the 1840 s, many proslavery advocates used scripture to show that slavery was socially and morally acceptable. First, they claimed that Noah's son Ham was black, and his descendants had been cursed by God to be forever subjected to bondage. Second, Abraham had purchased, sold, and traveled with his slaves, justifying the South's hope for the expansion of slavery. Third, Paul had

\footnotetext{
${ }^{260}$ Joseph Addison Turner, The Plantation (Mar 1860): 3-4, 48-1, 102-103; (Jun 1860): 324-329.

${ }^{261}$ John S. Haller, Jr., "The Species Problem: Nineteenth Century Concepts of Racial Inferiority in the Origin of Man Controversy," American Anthropologist, New Series, Vol. 72, No. 6 (Dec 1970), 13191329.

${ }^{262}$ Christopher A. Luse, "Slavery's Champions Stood at Odds: Polygenesis and the Defenses of Slavery," Civil War History, Vol. 53, No. 4 (Dec 2007), 381-385.

${ }^{263}$ Samuel A. Cartwright, "Report on the Diseases of and Physical Peculiarities of the Negro Race" (1851) from Defending Slavery: Proslavery Thought in the Old South, ed. Paul Finkelman (Boston: Bedford/St. Martin's, 2003), 157-173.

${ }^{264}$ Christopher A. Luse, "Slavery's Champions Stood at Odds: Polygenesis and the Defense of Slavery," Civil War History, Vol. 53, No. 4 (Dec 2007), 381-385.
} 
returned a slave to his master, which proslavery advocates used as evidence that the New Testament supported the idea of returning slaves to their owners - in other words, the Bible upheld the Fugitive Slave Act. Lastly, Jesus Christ never spoke a word about slavery; this became a sign that he did not condemn it, and therefore, it must not be a $\sin ^{265}$

Turner was a bit of an iconoclast on this score, as he expressed skepticism of these biblical defenses. In his March 1860 publication, The Plantation, he argued that there was no proof that Noah's son, Ham, was black. Nor was there evidence that Ham's descendants were the slaves on southern plantations. If southern slaves were the descendants of Ham, then why did the South not enslave the entire continent? he asked. Later, in The Countryman, Turner further implied his support for pseudo-scientific defenses when he denigrated the black race by publishing a tale of a master taking his slave to the zoo. Noticing similarities between the apes and himself, the slave talked to the ape. When the ape did not answer, the slave thought that it was best if the ape did not speak, otherwise his master would put a hoe in the hand and work him all day long. ${ }^{266}$ The analogy between slaves and apes reinforced the enslavement of blacks by imagining them as a separate species entirely - as animals.

\section{Class Struggles}

Slavery was a social and cultural institution that, for the most part, had unified southerners regardless of their slaveholding status. The planter elite, which represented the minority of the southern population, had used their wealth and local power to

\footnotetext{
${ }^{265}$ Drew Gilpin Faust, The Ideology of Slavery: Proslavery Thought in the Antebellum South, 1830 1860 (Baton Rouge: Louisiana State University Press, 1981), 136-163.

266 Joseph Addison Turner, “A Funny Incident,” The Countryman (May 19, 1863): 36.
} 
dominate southern politics. Historians debate the degree to which the planter elite dominated the South. Did their dominance mean that the middling or lower classes were fully subordinate and saw few political gains or did there exist a reciprocal relationship between the planters and yeoman farmers ${ }^{267}$ Stephanie McCurry suggests that the South's "herrenvolk democracy," in which to slavery, all white men could claim equality, was not in reality a true democracy since it created a privileged elite class of white male voters that dominated the majority of the disenfranchised population. Similar to the United States' Three-Fifths clause, southern state governments counted slaves as one person thus increasing the representation of the planter class in state legislatures. By including taxable property, such as slaves, in their count for electoral representation, the slaveholding class created a political majority. ${ }^{268}$

At the same time, she argues that the slaveholding elite appealed to the yeomanry and lower classes, whose support they needed, by emphasizing their independence as white men. By owning their own property, working for no other man, and controlling their own labor force, whether household dependents, such as wives, sons and daughters, or a few slaves, the yeomanry were masters of their own households, which lay outside the control and interference of slaveholding planters. ${ }^{269}$

The war challenged that unity by calling attention to the sacrifices, which took the form of manpower, money, and resources that were not evenly distributed across

${ }^{267}$ David R. Roediger, The Wages of Whiteness: Race \& the Making of the American Working Class (New York: Verso, 1991), 59-60.

${ }^{268}$ Stephanie McCurry, Masters of Small Worlds: Yeoman Households, Gender Relations, \& the Political Culture of the Antebellum South Carolina Low Country (New York: Oxford University, 1995), 93-96.

${ }^{269}$ Stephanie McCurry, Masters of Small Worlds: Yeoman Households, Gender Relations, \& the Political Culture of the Antebellum South Carolina Low Country (New York: Oxford University, 1995), 93-96, 177-184. 
southern classes. As noted in the previous chapter, the middling class, the yeomanry, and poorer white southern families felt the daily burden of war much more than elite planters. Turner thus used The Countryman to unite all southerners around their common interest in maintaining slavery. He argued that while other countries used white men for menial labor, the South had slaves to elevate the status of all white men. To further support his claim, he reprinted an article from The Tallahassee Floridian in March 1864 that was meant to rally non-slaveholders to the patriotic cause. It read: "They presume because we neither have lands nor slaves, that we are incapable of the sentiment of patriotism...we have never heard before that it was only the rich who were entitled to love their country, and their liberties, and to defend their rights. It is infamous to insult the poverty of a true Southern man by virtually charging him with having no interest in the welfare of his country." 270 The "poverty' referenced in the article specifically referred to those southerners who did not own slaves. All white southerners regardless of their slaveholding status, according to Turner, had a great stake in the war's outcome. Southern independence meant a continuation of the South's social structure and institutions, which presumably would maintain a level of equality across economic and class lines.

Turner also attempted to unite southerners by appealing to their sense of white mastery. For instance, he reasoned that the abolition of slavery would fall "in all its deadliest weight" on the yeomanry. Abolition, Turner asserted, would "break down the distinction based upon the color of the skin, and then other distinctions will arise." In his view, it was better for a black man to serve the white man than a white man to serve

${ }^{270}$ Joseph Addison Turner, “The Tallahassee Floridian,” The Countryman (Mar 8, 1864): 121. 
another. If blacks were cast out of the South, he argued, the white masses would be left to do the work of the slaves. ${ }^{271}$ The loss of slavery would create the greatest inequality when, “[a] white skin will no longer secure a man against servitude,” Turner wrote. ${ }^{272}$ Recognizing the internal dissensions among the classes, Turner urged southerners to understand the effects of losing slavery. His greatest fear, however, was not the impact on the non-slaveholder, but the loss of the institution itself.

The Emancipation Proclamation

As slavery was the cornerstone of southern society, Lincoln's Emancipation Proclamation rocked its very foundation. While some northerners viewed the proclamation as having divine purpose, redeeming the innocent, and atoning for the nation's sins, southerners and some northerners argued that it incited rebellion and upset southern society. ${ }^{273}$ When Lincoln officially announced his proclamation in September 1862, southern newspapers analyzed, demonized, and refuted it. ${ }^{274}$ Turner, however, did not publish any mention of the proclamation, future emancipation, or its impact on southern life. By refusing to acknowledge the proclamation, Turner, in his own way, downplayed the threat to Confederate nationalism. His silent response demonstrated his denial that the institution of slavery and the Confederate cause were at risk.

When the proclamation took effect on January 1, 1863, The Countryman again remained quiet. It was not until September 1863 that Turner urged diligence in controlling slaves. The looming threat of the proclamation's reach into southern territory

\footnotetext{
${ }^{271}$ Joseph Addison Turner, "Shall the Confederacy Abolish Slavery?" The Countryman (Feb 7, 1865): 70.

${ }^{272}$ Joseph Addison Turner, "Shall the Confederacy Abolish Slavery?" The Countryman (Feb 7, 1865): 70.

${ }^{273}$ George C. Rable, God's Almost Chosen People: A Religious History of the American Civil War (Chapel Hill: University of North Carolina Press, 2010), 224-227.

${ }^{274}$ The Courier (Oct 3, 1862).
} 
created a new sense of panic. Although the proclamation freed not one slave in the northern or border states, it served as a military strategy to weaken southern society. As Union forces conquered and captured southern territory, slaves within those occupied areas would immediately become emancipated, which in turn undermined southern morale by challenging the heart of Confederate nationalism.

As the war effort intensified and the southern armies felt defeat on the battlefield, southerners on the home front became more vigilant toward the slave population. Turner printed several articles on strict slave management and control. He cautioned slaveholders about topics discussed in front of slaves. Turner also emphasized that slave patrols remain vigilant as they monitored slaves who traveled with permission of their owner, as they sought out runaway slaves and as they disciplined defiant slaves. Additionally, he printed the Georgia slave code Sec. 4214 to remind all southerners, slaveholders and non-slaveholders alike, that their actions and words, whether written or spoken, had the potential to ignite a slave insurrection. This was meant as a clear reminder that all southerners must consciously remain aware and alert of their conduct and conversations in order to mitigate any chance of slaves learning of their release from bondage by Lincoln's Proclamation. ${ }^{275}$

Lifting his prolonged silence with these harsh reminders, Turner's cause for concern coincided with the appearance of federal troops in Georgia. From August through November 1863, the skirmishes and battles around and in Chickamauga and Chattanooga brought the Union army to Georgia. If the Confederates failed to push federal soldiers back, Turner feared that slaves might run towards Union lines or realize

\footnotetext{
${ }^{275}$ Joseph Addison Turner, "Exciting Insurrection,” The Countryman (Sep 22, 1863): 90; Joseph Addison Turner, "The Patrol Laws," The Countryman (Sep 22, 1863): 90.
} 
their emancipation depended upon federal control of the area. Either of these outcomes would slowly chip away at slavery and southern morale.

\section{Sherman's March through Georgia}

While Turner deployed multiple arguments to defend the institution of slavery, his argument against emancipation was strictly economic. He concerned himself primarily with the loss of property in slaves as he showed little to no concern for the slaves themselves. Paternalism seemed to have disappeared as quickly as it appeared in other arguments. Turner published accounts of economic loss that Sherman's march had on his fellow neighbors. Mrs. Reid, one of Turner's neighbors, had written Turner a letter stating that she had sent three of her slaves South to avoid being captured. ${ }^{276}$ Another account from Milledgeville detailed the loss of property in economic terms when they reported the town had been burned, and Sherman's armies had carried off livestock, provisions, and slaves. ${ }^{277}$ Turner was most likely projecting a common sentiment as white southerners clung to the fear of economic loss of their slaves as Sherman's troops conquered southern territory.

When Union General William Tecumseh Sherman marched his way across Georgia in the fall of 1864 and right through Turner's plantation, Turnwold, however, Turner shifted his emphasis away from the economic necessity of slavery to focus on the care and well-being of his slaves who were taken by Union soldiers. Sherman's march created new opportunities for slaves to abandon their existing situation. Southerners had built their defense of slavery around the notion that slaves were thankful for their position

\footnotetext{
276 Joseph Addison Turner, "The Coming of the Yankees," The Countryman (Dec 6, 1864): 672.

277 Joseph Addison Turner, "Incidents of Sherman's Southern Winter Tour," (Dec 20, 1864): 714.
} 
in southern society and never considered leaving their kind masters and warm homes. ${ }^{278}$ While most slaveholders believed this myth, they still held a constant fear that slaves were not grateful for their kindness. Loyalty, devotion, and faithfulness were thus called into question when Union troops were in close proximity. ${ }^{279}$ Turner's sudden concern with his slaves' well-being undoubtedly was meant to reinforce the edifice of paternalism that was now threatened. In describing the scene as one of his slaves left with Sherman's soldiers, Turner wrote with great passion: "Forced off, with tears in his eyes, in our presence, begging the yankees to let him stay." ${ }^{280}$ While this event most likely did not occur as Turner reported it, such somber words further solidified for his readers the belief that masters and slaves truly cared for one another.

Turner continued to cover the loss of slaves by Sherman's armies in The Countryman. As rumors emerged that Sherman was close to Eatonton, Georgia, Turner received letters from several of his neighbors, which he then published as first-hand accounts of Union activity for readers across the South. S.C. Prudden, an Eatonton resident and neighbor, wrote about the path of destruction left by Sherman and his troops. Another Eatonton resident, L.D. Rogers reported that Union forces were close to an Eatonton factory. On Sunday, November 20, 1864, Sherman's troops had arrived at Turner's plantation, Turnwold. Turner personally reported in The Countryman that Union soldiers stole his gold watch, silver spoons, hats, whisky, and a fiddle. In another article published the following day, he fumed at the loss of horses, mules, and his slaves, Tom,

\footnotetext{
${ }^{278}$ Drew Gilpin Faust, The Creation of Confederate Nationalism: Ideology and Identity in the Civil War South (Baton Rouge: Louisiana State University Press, 1988), 71-72.

${ }^{279}$ George C. Rable, God's Almost Chosen People: A Religious History of the American Civil War (Chapel Hill: University of North Carolina Press, 2010), 280.

${ }^{280}$ Joseph Addison Turner, "What We Lost," The Countryman (Dec 6, 1864): 676.
} 
Jack, and George. By Saturday, November 26, 1864, several of Turner's neighbors reported that their slaves had returned home, but his had not. ${ }^{281}$ This news coverage was meant to outrage his readers and reinforce a shared psychological experience of the suffering in war. Southerners felt the emotional stress and helplessness as victims of such atrocities. These bonds of victimhood forged a renewed unity around the Confederate cause. $^{282}$

In Turner's view, slaveholders were not Sherman's only victims. He not only accused Sherman of stealing his slaves, but also of placing them in a worsened condition and showing little regard for their position in life. For example, he wrote that while his slave, George, once had a nice warm bed in a dry comfortable home, Sherman had placed George in the cold trenches. In this story, Turner further exemplified his own benevolence as a slaveholder by depicting George as unwell and diseased. George, wrote Turner, was "the sickest nigger of his bargain that ever a mortal was." These types of comments illustrated Turner's purported kindness to his slave, who had deficiencies that most likely impaired George's ability to provide much economic benefit; yet, Turner cared for him from cradle to grave. He also urged for George's return because the chickens and turkeys missed him and he was sure George missed the animals too. In Turner's opinion, slave such as George with his supposed childlike intellect and maturity served little purpose in Sherman's possession. ${ }^{283}$

\footnotetext{
${ }^{281}$ Joseph Addison Turner, "The Coming of the Yankees," The Countryman (Dec 6, 1864): 672.

${ }^{282}$ Paul Quigley, Shifting Grounds: Nationalism and the American South 1848-1865 (Oxford: University Press, 2012), 9-10.

${ }^{283}$ Joseph Addison Turner, "Letter to Gen. Sherman," The Countryman (Feb 7, 1865): 74-75.
} 


\section{Slaves in the Confederate Army}

Since the Confederacy had been numerically outnumbered and overpowered from the beginning of the war, the Confederate government began seeking alternative solutions, including the conscription of soldiers and minimizing exemptions. Yet when Sherman's march proved that the conflict was a war of attrition, the Confederate manpower shortage had to be addressed in more radical ways. In 1863, the Confederate Congress had impressed twenty thousand slaves as laborers and teamsters to dig trenches, build bridges, and cook for the troops, allowing white southern men to fill the depleted ranks. The Confederate government used the slaves' labor, but the slaves still belonged to their masters. While slave labor impressment did not surprise most southerners, many slaveholders worried about their financial and labor loss. ${ }^{284}$

In March 1863, Turner wrote to the Confederate superintendent of slaves regarding his slave, Fountain. Turner was “anxious for his return home." Others had returned, "who went off at the time he did, and I don't see why he may not return also. I think the authorities act in bad faith to call out negroes for 30 days and then return them after 90." ${ }^{285}$ Although the Confederate government retained slaves longer than initially promised to slaveholders, the government later claimed that the use of impressed slaves did not have as great an impact on the southern war effort as they had expected. As a result, the Confederate government required further provision of slave labor, thereby making planter sacrifice unavoidable.

\footnotetext{
${ }^{284}$ Richard E. Beringer, Why the South lost the Civil War (Athens: University of Georgia Press, 1986), 368-370.

${ }^{285}$ Autobiography of Joseph Addison Turner, Robert Woodruff Library Microforms. Emory University, Emory, Georgia, March 2, 1863.
} 
Although Turner complained about the inconsistency around the enforcement of the slave impressment law, he continued to support the Davis administration's policies. One year later, in the fall of 1864, Jefferson Davis' address to the Confederate Congress proposed a "radical modification" to the original February 17, 1863 Impressment Act. Whereas in that act the slave had initially been viewed as property, Davis' speech concluded that "the slave...bears another relation to the state - that of a person." The initial 1863 law had been written around the relationship of master and slave, meaning that the slaveholders still owned the slave thus limiting the government's control over the slave. But the duration of the slave's impressment, the types of work completed, and the risk of runaways or potential death on the job were all liabilities that hindered the Confederate army. By compensating the slaveholders for their economic loss of property, the Confederate government removed these liabilities by assuming ownership of the entire person and his labor that was to be used for the duration of the conflict and in whatever position as seen fit.

Not surprisingly, slaveholders were not entirely sold on the idea of losing their valuable property even if compensated accordingly. By this point in the war, however, Turner supported Davis' plan. With four million slaves in the South, he reasoned that the loss of forty thousand slaves was a small price to pay for the survival of the institution. As to the idea of slave soldiers, Davis remarked that blacks only knew how to labor, not fight. He contended that there was a "broad, moral distinction" that existed between slave labor and slave soldiers. ${ }^{286}$

\footnotetext{
${ }^{286}$ Jefferson Davis, “President's Message,” The Countryman (Nov 22, 1864): 650-653.
} 
Within months of Davis' earlier remarks that blacks were incapable of fighting, the largest and most significant shift in Confederate legislation occurred. In one last desperate attempt to win the war, Davis proposed using blacks as soldiers, but, not surprisingly, opposition was ferocious. Black soldiers called into question the entire southern social order and the purpose of the war. The South had seceded to preserve racial inequality, not fight alongside slaves to ensure everyone's independence.

Southerners had long feared insurrections and uprisings with slaves in bondage; these thoughts were only heightened by the idea that slaves were to be armed with guns. ${ }^{287}$

Turner refused to accept the possibility that slavery could be lost. In the January 31, 1865 edition of The Countryman, in an article titled "What Ought to Be Done," he denounced the notion of slave soldiers, arguing that such a measure showed a willingness to negotiate for peace and made the South looked desperate. Turner revisited the reason for secession, writing that "it is a plain case" that the southern states seceded to preserve the institution of slavery, the bedrock of their culture and society. Independence, for Turner, meant freedom to regulate their own affairs including the institution of slavery "because we regarded it as the foundation stone of our social, and industrial systems, and the source of our prosperity." Turner wrote similar articles defending slavery in February and the beginning of March $1865 .^{288}$

Yet, "What Ought to Be Done" displays the contradictory nature of many of Turner's writings. While he regarded slave soldiers as an affront to the very foundation of southern society, he recognized its necessity and publicly supported the Davis

\footnotetext{
${ }^{287}$ Richard E. Beringer, Why the South lost the Civil War (Athens: University of Georgia Press, 1986), 368-370.

${ }^{288}$ Joseph Addison Turner, "What Ought to Be Done," The Countryman (Jan 31, 1865): 62.
} 
administration in arming the slaves as soldiers for the singular goal of preserving slavery. ${ }^{289}$ Turner favored "disciplining the largest possible number of negroes, as soon as possible, to be used [as soldiers], rather than have slavery destroyed. ${ }^{290}$ His shift in position was based on the circumstances of his time. Neither Turner nor anyone else knew how the war would end or that it would be over within two months. He saw this strategy as one that furthered the cultural institution of slavery and maintained the southern way of life since not all slaves would be conscripted, and the institution of slavery would continue to be economically profitable.

The issue of independence at the expense of slavery was a complex problem that challenged most white southerners. While Turner avidly argued that the South must either abandon the war or teach slaves to fight, others argued that removing slaves from the plantation fields hurt the war effort. To counter the claim that the use of slave soldiers was unconstitutional, Turner argued that slaveholders sent off their sons to be killed, but protested when it came to their property. When still others debated the destruction of slavery if slaves enlisted, he reminded them that if slaves were not mustered into service, slavery would die anyway. ${ }^{291}$

Even as he made these arguments, Turner continued to grapple with the problem that independence was meaningless without slavery, yet to win that independence slaveholders might have to sacrifice their slaves. In January 1865, Turner argued that the preservation of slavery rested on southern independence and the right to govern themselves and their institutions. Turner wrote, "What use have we for national

\footnotetext{
${ }^{289}$ Slaveowner, "Our Negroes," The Countryman (Aug 23, 1864): 448.

${ }^{290}$ Joseph Addison Turner, "What Ought to Be Done," The Countryman (Jan 31, 1865): 62.

${ }^{291}$ Joseph Addison Turner, "Negro Soldiers," The Countryman (Jan 17, 1865): 21.
} 
independence, with our institution taken away from us? None under heaven. We are not yet ready to let the nigger go. We want slavery preserved."292

\section{The Poor Free Slave}

Despite Turner's efforts to persuade his readers to support the government's initiatives necessary to win the war, those policies were initiated too late with too little support. The end of the Civil War meant an end to slavery and along with it, the southern way of life. It also meant freedom for four million slave men, women, and children, who no longer belonged to anyone else. ${ }^{293}$ The post-war era, however, created new challenges for the newly emancipated South. Turner, like many other former slaveholders, grappled with the reality of freed blacks and the loss of the their core institution. The Countryman's articles between May 1865 and April 1866 reflected three common postwar themes: the South's unwillingness to accept the demise of slavery; the North's responsibility for the former slaves' predicament; and judgment of freedmen's work ethic.

First, Turner refused to accept that slavery no longer legally existed in the South. In June 1865, he wrote in The Countryman that he did not believe the Union would abolish slavery. In fact, he refused to even consider the abolition of slavery as it "sounds too silly to contemplate." Turner argued that Lincoln's Emancipation Proclamation was not legal. He also discounted the passage of the Thirteenth Amendment that had passed Congress in January of that year because he claimed it had not been ratified by the requisite three-fourths majority of the states, including the Confederate states as part of

\footnotetext{
${ }^{292}$ Joseph Addison Turner, "What Ought to Be Done," The Countryman (Jan 31, 1865 ): 62.

${ }^{293}$ Eric Foner, Forever Free: The Story of Emancipation and Reconstruction (New York: Vintage Books, 2005), 76-80.
} 
the Union. He clung to the belief that the courts would legally uphold his claim to owning slaves. $^{294}$

Even as he denied the abolition of slavery, Turner denounced the North for placing blacks in the worst possible situation by abolishing slavery. He turned emancipation into a burden far worse than slavery when he wrote, "Poor negroes! Once they were taken care of and protected, now they have none." Slaves, he believed, would no longer be safe, secure, and nurtured outside of their household. Emancipation would offer none of the kindness or mercy that slaveholders believed they provided their slaves. Slaves would curse the day of their freedom because, Turner believed, they had nothing of their own, but their freedom. ${ }^{295}$

He demanded the United States government take responsibility for the slaves since they were the ones who freed them. The federal government "cannot make the negro what God never designed him to be." Yet, at the same time, Turner complained that the United States would make freed slaves "the pet of the federal government" making them "more than equal of the white man."296 Blaming the North for placing former slaves in the same predicament as that of northern wage laborers, Turner argued that former slaves faced the same troubles as the northern counterparts by struggling to feed and clothe their families; all of which had been previously provided under the institution of slavery by their former masters. ${ }^{297}$ Even after the war, Turner rationalized

\footnotetext{
${ }^{294}$ Joseph Addison Turner, “The Negroes," The Countryman (Jun 13, 1865): 298.

295 Joseph Addison Turner, "The Negroes," The Countryman (May 23, 1865): 285.

${ }^{296}$ Joseph Addison Turner, "What is to become of the Negro," The Countryman (Feb 13, 1866): 18.

297 Joseph Addison Turner, "The Negroes," The Countryman (Jun 13, 1865): 298.
} 
slavery as a benevolent institution and represented slaveholders as great paternalists who deeply cared for their slaves by providing for their needs. ${ }^{298}$

Freedom, according to Turner, denigrated slaves from their previous position. It brought laziness, idleness, and a complete disregard for their former owners. Turner's personal journal is filled with such interactions between him and his former slaves. Through these stories, Turner shows how he viewed emancipation and its impact on his former wards. According to his journal dated February 13, 1866, Turner built a tank that had been filled with water to ensure it was properly sealed before it was used in the production of brandy. Matt was "a great burly, giant, stinking specimen of the "American citizen of de African scent'," proceeded to bathe in it, but remarked that he would have washed it out before putting brandy in it. "Wash it hell, you had just as well attempt to wash out hell, to wash out that tank, after it has held your stinking carcass," fumed Turner. He believed his slave's freedom created an environment where Matt demonstrated indolence and outright disrespect to him as his former caregiver. Clearly Matt was asserting his new freedom. If Matt had not been emancipated, Turner believed the incident would never have occurred because Matt would have followed traditional southern race relations that had once defined the relationship between master and slave. $^{299}$

Turner's personal journal detailed the conduct of his former slaves. While he denounced their post-emancipation behavior, he documented their new manners to prove emancipation's effects. In his "List of Colored Persons Lately belonging to J.A. Turner,"

\footnotetext{
${ }^{298}$ Joseph Addison Turner, "Nigger Freedom," The Countryman (May 30, 1865): 290.

${ }^{299}$ Autobiography of Joseph Addison Turner, Robert Woodruff Library Microforms. Emory University, Emory, Georgia, July 9, 1865.
} 
he outlined for the federal government the name, age, and description of his twenty-five slaves and eight hired hands. The sketches reflected his belief that freed slaves were useless for future work. For example, "Big Patience, age 30, was diseased, does but little; Della, about 20 and left three or four weeks ago without giving notice and without provocation; Charles, age 55, mechanic, very slow and uncertain, left by my permission to obtain work; and Jim, age 55, knockneed [sic] and infirm." 300

In 1866, a full year after the war's end, Turner continued to lament the tragedy of emancipation and the chaos that he believed was left in its wake. In one of the last issues of The Countryman, he wrote:

To 'free' the nigger, as his lovers say Which means to take his peace, his life away;

To disappoint him with deceitful dreams, To drag him where some ignis fatuus gleams, And lures him on to things he ne'er can reach, To rot his carcass in some friendly ditch; To take him from a once contented home, O'er earth a thieving vagabond to roam; Free to be idle, free to work no more, Free to behold his happiest moments o'er; Free to possess no shelter for his head, Free to know want of even the coarsest bread;

Free to be hungry, free to feel the cold, Free to be naked, and no more behold The comforts that surrounded him ere be Had thrust on him, the curse of being free; Free to lead out a life of misery, Free to lie down in poverty, and die! And yet to gain this freedom for the nigger, For four long years, men pulled the deadly trigger. ${ }^{301}$

\footnotetext{
${ }^{300}$ Autobiography of Joseph Addison Turner, Robert Woodruff Library Microforms. Emory University, Emory, Georgia, July 9, 1865.

${ }^{301}$ Joseph Addison Turner, "The Nigger: A Satire," The Countryman (May 1, 1866): 108-111. 
Relying once again on paternalism, Turner's poem focused on what he viewed as the negatives of a slave's life after emancipation. His satirical style of writing emphasized the so-called freedoms that slaves gained as a result of their emancipation all of which were depicted negatively in order to show that slaves previously had not to worry about such matters. Turner also played on the paternalistic positives of the institution when he continued his poem with:

"Why should they care? A master's ready hand Responsive stood to serve their least demand To give them food - their raiment to provide To give them shelter - watch their beds beside, When fever racked them - and, when they were dead,

To smooth, at last, their cold and narrow bed.

The happiest race on earth were Nigger slaves, The happiest from their cradles to their graves. ${ }^{302}$

Turner's poem was never completed. The second installment was to appear in the next issue of The Countryman, which abruptly closed its doors with the final issue on May 8,1866 . While we may never know how the poem ends, Turner makes clear that without the institution of slavery and the southern way of life that hinged on its existence, his world no longer existed.

Cultural nationalists like Turner faced their greatest challenge in defending slavery as the fabric of southern society. For Turner the challenge was probably greater as he embraced often conflicting views about slaves, slaveholding, and the institution itself. By defending slavery in a multitude of ways, Turner attempted to form a broad consensus in support of the institution.

He also wrestled with the notion that southern independence might only be achieved at the sacrifice of their key cultural institution. Yet, without slavery, the fight

302 Joseph Addison Turner, “The Nigger: A Satire,” The Countryman (May 1, 1866): 108-111. 
for sovereignty seemed meaningless. Turner understood the importance of being distinctly southern and independent, but not at the expense of losing the one institution that held the rest of society together. For Turner, slavery was the first priority for southerners, regardless if it existed in a separate nation or in the former Union. Without slavery, the South had lost its identity and with it their regional self-interests, allegiances, and loyalties. 


\section{CHAPTER V \\ CONCLUSION}

From 1862 to 1865 , Turner proudly published The Countryman to promote southern intellectual independence, to build a national community around devotion to the Confederate nation, and to encourage support of the South's cultural institutions. So when Turner learned of the fall of Richmond and the defeat of the Confederacy, he was not anxious to report it to his readers. Turner's own denial and his unwillingness to report the news of the Confederacy's fate was the first step in The Countryman's shifting literary tone. In an attempt to downplay Confederate losses that would potentially dishearten his readers, Turner did not print them as front page news; rather, he tucked those articles away from his readers' immediate view by placing them in the issue's back pages. In the May 2, 1865 edition, Turner printed the news of the fall of Richmond, which had occurred earlier in April, at the bottom corner of a column on page four. Six pages later, more than half way through the issue, he reported on "The State of The Country" that announced the formal surrender of General Lee and the Army of Northern Virginia. ${ }^{303}$

By late May 1865, Turner's writings had become defiant against the United States government, its military occupation of the South, and reconstruction that was underway. Since Confederate politicians had been placed under arrest and the southern people were

\footnotetext{
${ }^{303}$ Joseph Addison Turner, "The State of The Country," The Countryman (May 2, 1865): 266.
} 
without leaders, Turner believed that "our people look, in some measure, to their public journalists for instruction" about the proper course the South should pursue in reconstruction. Although he used The Countryman to provide guidance to the southern people, Turner also showed the emotional anguish felt by many southerners at the time. Again, as with his writings throughout the war, Turner's responses were often contradictory. On the one hand, he encouraged southerners to resist if there was any hope to do so successfully in order to keep the Confederacy alive; but, on the other hand, he also instructed them to obey the laws of the nation as if accepting the reunion of North and South. Additionally, Turner publicly insulted the United States government by referring to them as "conquerors" and calling them despotic. He was clearly trying to put up a fight if there was a sliver of a chance that the Confederacy would survive, yet, at the same time, he offered the illusion that he obeyed the federal government and that southerners accepted their defeat. ${ }^{304}$

The most controversial article Turner penned after the fall of the Confederacy was his "The Five Points" plan, or what he later republished as "Our Platform of American Principles." Turner was convinced that reconciliation between the North and South would only occur if the Federal government did not force the South back into the Union, but instead made concessions that would entice southerners to rejoin the Union. Specifically, Turner outlined five points: a new flag since Confederates had fought against the American flag and it had waved over "their bloody graves, ruined homes, and burned towns;" a new Constitution as the old one was not sufficient to support southern rights such as secession and slavery; a "full and complete acknowledgment of our states' rights

${ }^{304}$ Joseph Addison Turner, "The Proper Course," The Countryman (May 16, 1865): 281. 
and state sovereignty" along with the recognition of the institution of slavery; the abnegation that the southern people were rebels or committed acts of treason; and the consolidation of all war debt. In his own way, Turner attempted to remake the new United States in the image of South's former self. The formation of the Confederacy in 1861 had allowed the South to establish new symbols that represented the South, its people, and culture. Similarly Turner wanted a new start with the post-war United States, but the new nation had to recognize the importance of southern interests and institutions. ${ }^{305}$ In hopes of influencing and persuading the reunification process, Turner printed "Our Platform of American Principles" in every June 1865 issue. More than anything else, Turner imagined that slavery could survive reunion.

Turner's public remarks, criticisms, and demands printed in The Countryman did not go unnoticed and did not escape repercussions. On June 26, 1865, he was placed under military arrest by Union General Wilson in Macon, Georgia for publishing material considered disloyal to the Union. As punishment, he was forced to suspend The Countryman's publication. ${ }^{306}$

Once released from military arrest, Turner re-commenced publication of The Countryman on January 30, 1866. When his readers received the paper for the first time in over six months, they read Turner's account of his arrest on the front page. He described his interrogation by the military as "very rough talk, amounting to the grossest insult." ${ }^{307}$ He then defended himself by pointing out that "we can only hope the day will speedily arrive when the constitution of the United States will extend its protecting power

\footnotetext{
305 Joseph Addison Turner, "The Five Points," The Countryman (May 23, 1865): 285.

${ }^{306}$ Joseph Addison Turner, "Afloat Once More," The Countryman (Jan 30, 1866): 1.

307 Joseph Addison Turner, "Autobiography of The Countryman," The Countryman (Feb 13, 1866):
} 20-22. 
around every American citizen, and give us, once more, freedom of the press.." ${ }^{308}$ This would be the last controversially charged article that he printed.

Turner's efforts to incorporate a southern national ideology into the larger nation proved untenable. He had tirelessly labored for four years to forge a Confederate identity through print culture. The Countryman had played a pivotal role in promoting a Confederate nation of avid readers and influential writers who established the nation's intellectual independence; in encouraging faithful devotion and patriotic support of the Confederate nation; and in defending the institution of slavery by demonstrating its cultural importance to southern society. But from January 30, 1866 until May 8, 1866, The Countryman did not resemble its former self. Since Turner felt he could no longer promote southern nationalism in the midst of Reconstruction, he changed The Countryman's motto to "Devoted to the Editor's Opinion," and limited the articles to simpler topics about livestock and hunting, poems and odes to Confederate generals, reprinted articles from other papers, and the occasional commentary on the condition of the emancipated slaves. The Countryman was no longer a rallying cry for the southern people, its institutions, or nation. ${ }^{309}$

At what point Turner decided to cease publication of The Countryman is unknown. He left no hint or suggestion in the issues leading up to the last edition, after which he returned to his law practice until his death in 1868. Similar to the ways in which he shared the bad or sorrowful news of the Confederacy's demise, Turner published his farewell article in the back pages of the May 8, 1866 issue. In "ADIEU!" he

\footnotetext{
308 Joseph Addison Turner, “Afloat Once More,” The Countryman (Jan 30, 1866): 1.

309 Joseph Addison Turner, "Autobiography of The Countryman," The Countryman (Feb 13, 1866):
} 20-22. 
reminiscenced about his former life as a planter, which he considered to be "the highest type of man, as I conceive it, that the world has ever produced." His loss of position and stature, according to Turner, was the divinely-sanctioned result of "the severe chastisement of war." Turner viewed the South's defeat and the abolition of slavery as the work of God, not the North. As a result of Confederate defeat, his occupation, social status, plantation home, and country no longer existed. He felt that "living in the same spot where I always did, I am, nevertheless, an exile and a wanderer.” Feeling like a stranger in a new country, Turner felt no other option other than to cease publication entirely. His final words read, "I cannot longer publish The Countryman. It was a representative of Independent country life, and of the home of the planter. These are gone, and The Countryman goes with them. - Farewell!",310

${ }^{310}$ Joseph Addison Turner, “ADIEU!” The Countryman (May 8, 1866): 118. 


\title{
REFERENCES
}

Newspapers

The Countryman, Eatonton, Georgia (1862-1866)

The Plantation: A Southern Quarterly Journal, New York (1860)

\author{
Archival and Microforms
}

Autobiography of Joseph Addison Turner. Robert Woodruff Library Microforms. Emory Library \& Information Technology, Emory, Georgia.

Published

Cartwright, Peter, Autobiography of Peter Cartwright. Edited by Charles L. Wallis. Nashville: Abingdon Press, 1984.

Nott, Josiah C., M.D., Two Lectures on the Natural History of the Caucasian and Negro Races. Mobile: Dade and Thompson, 1844.

Turner, Joseph Addison, Autobiography of "The Countryman", 1866. Edited by Thomas H. English. Georgia: The Library Emory University, 1943.

\section{Secondary Sources}

Anderson, Benedict, Imagined Communities, Reflections on the Origin and Spread of Nationalism. London: Verso, 2006. 
Bernath, Michael T., Confederate Minds, The Struggle for Intellectual Independence in the Civil War South. Chapel Hill: University of North Carolina Press, 2010.

"Independent in Everything - Neutral in Nothing": Joseph Addison Turner, The Countryman, and the Cultivation of Confederate Nationalism." Georgia Historical Quarterly 96, no. 1 (Spring 2012): 24-55.Berry, Stephen W., "The South: From Old to New." Blackwell Companion to American History: A Companion to $19^{\text {th }}$ Century America, ed. William L. Barney, 258-271. Blackwell Publishing, 2006.

Binnington, Ian, They have made a nation": Confederates and the Creation of Confederate nationalism. Ph.D. Dissertations, University of Illinois, 2004.

Bolton, Charles C., "Planters, Plain Folk, and Poor Whites." Blackwell Companion to American History: A Companion to the Civil War and Reconstruction, ed. Lacy K. Ford, 75-93. New York: Wiley-Blackwell Publishing, 2011.

Clinton, Catherine. The Plantation Mistress: Woman's World in the Old South. New York: Pantheon Books, 1982.

Dew, Charles B., "The Slavery Experience.” in Interpreting Southern History: Historiographical Essays in Honor of Sanford W. Higginbotham, ed. John B. Boles and Evelyn Thomas Nolan, 120-161. Baton Rouge, LA: Louisiana State University Press, 1987.

Eberhard, Wallace B., Dictionary of Literary Biography, Volume 79: American Magazine Journalists, 1850-1900. Detroit: Gale, 1989.

Escott, Paul, After Secession: Jefferson Davis and the Failure of Confederate Nationalism, Baton Rouge: Louisiana State University Press, 1978.

Fahs, Alice, The Imagined Civil War: Popular Literature of the North \& South, 18611865. Chapel Hill: University of North Carolina Press, 2001.

Faust, Drew Gilpin, The Creation of Confederate Nationalism: Ideology and Identity in the Civil War South. Baton Rouge: Louisiana State University Press, 1988. 
The Ideology of Slavery: Proslavery Thought in the Antebellum South, 18301860. Baton Rouge: Louisiana State University Press, 1981.

"The Peculiar South Revisited: White Society, Culture \& Politics in the Antebellum Period, 1800-1860." in Interpreting Southern History:

Historiographical Essays in Honor of Sanford W. Higginbotham, ed. John B. Boles and Evelyn Thomas Nolan, 78-119. Baton Rouge, LA: Louisiana State University Press, 1987.

This Republic of Suffering: Death and the American Civil War. New York: Vintage Civil War Library, 2008.

Fuchs, John A. "Southern Nationalism and the Promise of Individual Rights and Freedom - Reflected in History, Politics and Literature." The Americanist, Volume 25 (2009): 129-146.

Genovese, Eugene D., Roll Jordan Roll: The World The Slaves Made. New York: Vintage Books, 1976.

The World the Slaveholders Made: Two Essays In Interpretation. New York: Pantheon Books, 1969.

Goen, C.C., "Broken Churches, Broken Nation: Regional Religion and North South Alienation in Antebellum America." Church History, Vol. 52, No. 1. (Mar 1983): 21-33.

---------. Broken Churches, Broken Nation: Denominational Schisms and the Coming of the Civil War. Macon: Mercer University Press, 1985.

Haller, Jr., John S., “The Species Problem: Nineteenth Century Concepts of Racial Inferiority in the Origin of Man Controversy." American Anthropologist, New Series Vol. 72, No. 6 (Dec 1970): 1319-1329.

Harrill, J. Albert, "The Use of the New Testament in the American Slave Controversy: A Case History in the Hermeneutical Tension between Biblical Criticism and 
Christian Moral Debate." Religion and American Culture: A Journal of Interpretation, Vol. 10. No. 2 (Summer 2000): 149-186.

Heyrman, Christine Leigh, Southern Cross: The Beginnings of the Bible Belt. The University of North Carolina Press: Chapel Hill, 1997.

Huff, Lawrence. “A Bitter Draught We Have Had to Quaff: Sherman's March Through the Eyes of Joseph Addison Turner." The Georgia Historical Society 72, no. 2 (Summer 1988): 306-326.

"Joseph Addison Turner: A Study in the Culture of Ante-Bellum Middle Georgia." ProQuest Dissertations and Theses: 1958.

-- "Joseph Addison Turner an His Quarterly, the Plantation." The Georgia Historical Society 54, no. 4 (Winter 1970): 493-506.

“Joseph Addison Turner's Role in Georgia Politics, 1851-1860." The Georgia Historical Society 50, no. 1 (March 1966): 1-13.

"Joseph Addison Turner: Southern Editor during the Civil War." The Journal of Southern History 29, no. 4 (November 1963): 469-485.

Johnson, Walter. Soul by Soul: Life inside the Antebellum Slave Market. Cambridge, MA: Harvard UP, 1999.

Luse, Christopher A. "Slavery's Champions Stood at Odds: Polygenesis and the Defense of Slavery." Civil War History, Vol. 53, no. 4 (December 2007): 379-412.

Nelson, Dana D. "The Haunting of White Manhood: Poe, Fraternal Ritual, and Polygenesis." American Literature, Vol. 69, no. 3 (September 1997): 515-546.

Nolan, Alan T., "The Anatomy of the Myth," The Myth of the Lost Cause and Civil War History, ed. Gary Gallagher and Alan T. Nolan (Indiana: Indiana University Press, 2000), 16-30. 
Matthews, Donald G. Religion in the Old South. The University of Chicago Press: Chicago, 1977.

McCurry, Stephanie. "The Two Faces of Republicanism: Gender and Proslavery Politics in Antebellum South Carolina." The Journal of American History (March 1992): 1245-1263.

- Masters of Small Worlds - Yeoman Households, Gender Relations, and the Political Culture of the Antebellum South Carolina Low Country. Oxford: University Press, 1995.

Menand, Louis. "Morton, Agassiz, and the Origins of Scientific Racism in the United States." The Journal of Blacks in Higher Education, No. 34 (Winter 2001-2002): 110-113.

Moore, James. "Darwin's progress and the problem of slavery." (lecture, Progress in Human Geography, Royal Geographical Society with the Institute of British Geographers, University of Manchester, August 29, 2009.)

Quigley, Paul, Shifting Grounds: Nationalism and the American South 1848-1865. Oxford: University Press, 2012.

Paine, Gregory L. "Regional Pride", South Atlantic Bulletin 9, No. 4 (February 1944): 89.

Pessen, Edward. "How Different from Each Other Were the Antebellum North and South?" The American Historical Review, Vol. 85, No 5 (Dec 1980): 1119-1149.

Phillips, Ulrich B. "The Central Theme of Southern History" The American Historical Review, Volume 34, no. 1 (October 1928): 30-43.

Potter, David M. “The Historian's Use of Nationalism and Vice Versa.” The American Historical Review, Vol. 67, No. 4 (July 1962): 924-950. 
Rable, George C, God's Almost Chosen People: A Religious History of the American Civil War. Chapel Hill: University of North Carolina Press, 2010.

Rubin, Anne Sarah, "Seventy-six and Sixty-one: Confederates Remember the American Revolution," in Where Those Memories Grow: History, Memory, and Southern Identity. Chapel Hill: University of North Carolina Press, 2000.

Uncle Remus Bookstore, Research \& More, Biographical articles, http://www.uncleremus.com (accessed December 29, 2013).

Varon, Elizabeth R., Disunion! The Coming of the American Civil War, 1789-1859. Chapel Hill: University of North Carolina, 2008. 